Portland State University

PDXScholar

Spring 6-19-2017

\title{
Identity and Community in Rural Higher Education: Creating New Pathways to Women's Leadership in Oaxaca, Mexico
}

Amanda Marie Elder

Portland State University

Follow this and additional works at: https://pdxscholar.library.pdx.edu/open_access_etds

Part of the Education Commons, and the Women's Studies Commons Let us know how access to this document benefits you.

Recommended Citation

Elder, Amanda Marie, "Identity and Community in Rural Higher Education: Creating New Pathways to Women's Leadership in Oaxaca, Mexico" (2017). Dissertations and Theses. Paper 3677.

https://doi.org/10.15760/etd.5561

This Thesis is brought to you for free and open access. It has been accepted for inclusion in Dissertations and Theses by an authorized administrator of PDXScholar. Please contact us if we can make this document more accessible: pdxscholar@pdx.edu. 
Identity and Community in Rural Higher Education:

Creating New Pathways to Women’s Leadership in Oaxaca, Mexico

by

Amanda Marie Elder

A thesis submitted in partial fulfillment of the requirements for the degree of

\author{
Master of Arts \\ in \\ Anthropology
}

Thesis Committee:
Charles Klein, Chair
Jack Corbett
Michele Gamburd

Portland State University

2017 


\begin{abstract}
The emergence of higher education opportunities in rural areas of Mexico such as throughout the state of Oaxaca has opened new opportunities for young women's professional development and new individual and community identities. I explore tensions between the collective imaginary of rural Mexico and rural women's emerging sense of independence and self-determination in light of higher education's expanding opportunities, leading to community formation around commonality of experience in addition to ascribed community relationships and roles. I situate this analysis within the context of the Universidad Tecnológica de los Valles Centrales de Oaxaca (UT), a small university in San Pablo Huixtepec, Oaxaca, Mexico. Through interviews and participant observation, I answer the following questions: (1) How is rural women's identity produced through policy, geography, and social influences? (2) In what ways do college women experience change in terms of family relationships and professional trajectories? and (3) How do changes in rural women's collective identity through professional development contribute to social movements for gender equality? This thesis provides a broader examination of the implications of shifts in family trajectory for belonging and women's identity in Mexico, contributing to larger discussions regarding higher education in rural areas, women's experiences and interactions within institutions, and women's collectives as venues for societal transformation. In conclusion, I offer recommendations for educational policy that supports women's identity development, promotes gender equality, and encourages women's leadership.
\end{abstract}




\section{Dedication}

I dedicate this thesis to women in the global lucha for gender equality. 


\section{Acknowledgements}

Individual accomplishments are often due to the collective contribution of many people, and achievements are sweeter when shared with others. This thesis is no exception, and I plan on sharing the joy of completing it with those who have supported me during my education and using the completion of this graduate degree as the groundwork for supporting other women throughout my professional career.

First, thank you to the Anthropology Department and my thesis committee, Dr. Charles Klein, Dr. Michele Gamburd, and Dr. Jack Corbett for your academic guidance and insight and feedback on previous drafts. I also thank the various organizations that have funded my graduate education. The Ford Family Foundation has invested in my education and success, an act of generosity I am committed to paying forward through my career. Thank you to the Southwest Center for International Studies, the Ron and Jane Cease Founders Award, the IAP2 Cascade Chapter, the Laurels Graduate Award, the State Treasurer Urban Pioneer Scholarship, the Frank Roberts Community Service Scholarship, Thomas M. Newman Scholarship, and the Judith Ramaley Community Engaged Scholarship for their contributions to my education and success. Thank you to Fulbright García-Robles and the Ronald E. McNair Scholars programs for providing funding for this research.

Agradezco infinitamente a las mujeres oaxaqueñas que me han brindado su amistad y cariño durante estos años de colaboración, siendo mis mejores maestras de 
vida, colaboración, y dedicación a metas. Gracias sobre todo a mis amigas y colegas, el equipo del Centro Universitario para el Liderazgo de la Mujer, mujeres emprendedoras e inspiradoras: Mstra. Nydia Mata Sánchez, Lic. Dulce Martínez Fabián, y Ing. Lucila Hernández Ruíz. Gracias a la Universidad Tecnológica de los Valles Centrales de Oaxaca por haber permitido y facilitado esta investigación, especialmente al Mstro. Julián Luna Santiago y a todas las alumnas de la institución que me brindaron su confianza durante las entrevistas realizadas. Agradezco a la Dra. Margarita Dalton del CIESAS Pacífico-Sur por la orientación teórica al contexto oaxaqueño y por invitarme a colaborar y participar en el Seminario del Género. A las chicas participantes del CMujer, las agradezco por sus ganas de aprender, compartir, y cambiar el mundo.

I have been privileged to share my graduate education experience with inspiring, intelligent, motivated, engaged, kind, and generous women who have taught me so much about friendship. First, I thank my best friend in the world, Haley Jones, for always keeping it real and making me laugh harder than anyone else. She stays up irresponsibly late with me, helping me decompress with my absolute favorite conversations and bad reality television. She also never complained even once about the fact that I took over our kitchen table for months so that I could write this thesis, and when I was stressed she encouraged ice cream indulgence. She also brought my dog nephew, JD Jones, into our lives; his happy face distracted me at all the right times.

Next, my crew at Portland State is irreplaceable. Harmony, you extraordinary wonder woman, you set such a great example of caring generosity and incomparable 
multitasking. Hannah, thank you for your lighthearted and always fun friendship. Monica, thank you for encouraging my physical and mental health and for making me use Zotero. Laura, my rad neighbor, you inspire me to set professional goals, take them seriously, and then do the work. Ariel, the intentionality with which you pursue and combine your personal and professional interests gives me an example of how to be a whole person.

Ed, thank you for being gentle and patient during each of my thesis- and grad school-induced crises that happened roughly every ten weeks, sharing learning with me about topics unrelated to immense social issues, and being the President of my fan club. You are a crystal-clear cenote after a hot Yucatecan bike ride, a glass of Vietnamese rum chilled by melting ice, a glug of tejate in a Oaxacan mercado, and a scoop of Umpqua ice cream that you eat before it melts in the Sherm's parking lot. Like all these things, you are a refreshing and joyful addition to my life. I promise to make you soup when you are in graduate school.

My debts to the people who had the patience to put up with me while I learned Spanish are immense. To all the people in Mexico who had to figure out what I was trying to say, thank you for not making me fun of me (that I know of). To my friends in Mexico who do make fun of me, thanks for keeping me on my toes. Carrie, thank you for being my Spanish-learning buddy for years now and for having the good sense to marry Marisol, who I also adore.

Thank you, Mom and Dad, for always encouraging me and making prioritizing 
my education possible, for providing support and love, and giving me my first scholarships: five dollars for earning an A and two dollars for a B in elementary school. My parents patiently attended award ceremonies through my undergraduate and graduate education and made sure I always had a warm and food-filled space to come home to. Thank you for encouraging me to git ' $\mathrm{r}$ dun. Also thank you to my grandma who gave me my first foundation for academic success by teaching me to read.

I have been fortunate to receive support from $\mathrm{TRiO}$ and other programs throughout my education. At Umpqua Community College I had excellent role models who helped set me on a successful path through the Transfer Opportunity Program: Pam, Mandie, and Sue. At Portland State University, thank you Liane Kehaulani O'Banion in the Learning Center for being a compassionate and supportive supervisor and to the Ronald E. McNair Scholars program, especially Dr. Toeutu Faaleava and Dr. Jolina Kwong, for setting me up for success, providing a pathway to graduate school and the opportunity to be mentored by Jack.

I could write a thank you letter as long as this thesis to Dr. Jack Corbett. There is no other person who has made a bigger impact on my life and education or taught me more about deep solidarity, commitment, generosity, and how to work the system. Jack had vision for my academic trajectory before I even understood the implications and patiently and strategically accompanied me along this path as my advocate, friend, and colleague. He consistently leads by example and is a model of meaningful collaboration and support for others. Thank you so much. 


\section{Contents}

Abstract $\quad$ i

Dedication $\quad$ ii

Acknowledgements $\quad$ iii

List of Figures $\quad$ ix

Chapter 1 - Understanding Rural Women's Experiences: Context, Theory, and Methodological Approach 1

Socioeconomic and Institutional Context 3

Oaxaca, Mexico 3

San Pablo Huixtepec and the Universidad Tecnológica de los Valles Centrales de Oaxaca 5

Thesis Structure and Theoretical Outline $\quad 12$

Methodological Approach: Confianza and the Role of the Researcher 16

Participant Observation and Activist Anthropology 16

$\begin{array}{ll}\text { Interviews } & 18\end{array}$

Ethnographic Vignette and Memes 20

Data Analysis $\quad 21$

Recruitment $\quad 21$

Positionality 23

Chapter 2 - Producing Space and Identity in Rural Oaxaca 25

Spatial Practices: Contrasting Kitchenspaces in Rural Oaxaca 31

Representations of Space: "Conocimiento Práctico que Transforma" 40

Spaces of Representation: "We All Came to Learn" 47

Chapter 3 - The Profesionista's Borderlands: Family Belonging, Conflict, and Transformation $\quad 54$

Conocimiento Stages One Through Three: Seismic Shifts and Transformation 59

Conocimiento Stages Four and Five: "Remembering Where You're From" 65

Stage Six: Choques and Family Conflict $\quad 71$

Socioeconomic Mobility 73

Women's Family and Community Role $\quad 75$

Unfamiliarity with Student Life $\quad 80$

The Seventh Stage of Conocimiento: Becoming a Profesionista in the Borderlands 82

Chapter 4 - Building Community in the Thirdspace: CMujer as Convergence and Transformation 
Creating CMujer: El Dream Team and Organization Forming 93

El Dream Team $\quad 95$

Program Development $\quad 98$

$\begin{array}{ll}\text { Participants } & 102\end{array}$

University Response to CMujer 103

CMujer as a Thirdspace: Collective Identity and Transformation in the Borderlands 104

Chapter 5 - Conclusions and Recommendations: ¡Pa'delante, Mujeres! 117

Contradictions and Challenges: ¿Y Ahora Qué Hacemos? 119

Institutionalizing and Expanding CMujer 123

Final Reflections on Women's Leadership 128

$\begin{array}{ll}\text { References } & 130\end{array}$

$\begin{array}{ll}\text { Appendices } & 144\end{array}$ 


\section{List of Figures}

Figure 1 - State of Oaxaca, Mexico

Figure 2 - Indicators of poverty: Oaxacan household compared to national household average (2010)

Figure 3 - Percent of population having completed higher education 5

Figure 4 - Universidad Tecnológica de los Valles Centrales de Oaxaca logo 6

Figure 5 - Number of students in each program of study by gender 7

Figure 6 - Entrance to the Universidad Tecnológica de los Valles Centrales de Oaxaca 10

Figure 7 - Interviewees' parents' highest level of schooling achieved 19

Figure 8 - Me unsuccessfully making tortillas in Emma's kitchen 28

Figure 9 - A typical home in the Tlacolula Valley 33

Figure 10 - A UT students' mother polishes her metate and metlapil, the tools used for grinding corn into masa for tortillas, with pumice stone in her kitchen 35

Figure 11 - Students working in the Gastronomy kitchens at the UT 36

Figure 12 - View of the UT and newly planted trees from the top of the library 40

Figure 13 - Lupe reading with children in her community during a CMujer service project 84

Figure 14 - Linda accepting the results of her exam while her parents and family members look on

Figure 15 - Las Señoras (in pink), Victoria (center, dressed in white chef's uniform), the local psychologist (center, black shirt), and the CMujer team (Dulce, far left; me, back row, second from the right; Lucy, back row, far right) at the graduation ceremony 91

Figure 16 - Centro Universitario para el Liderazgo de la Mujer logo 93

Figure 17 - Me (back, left), Lucy (back, center), Nydia (front, left), and Dulce (front, center) during breakfast on Independence Day with other members of the Outreach Department

Figure 18 - El Balero Club de Lectura Móvil in action 100

Figure 19 - Día Naranja at the UT 101

Figure 20 - Cintia and the Sembrando Oportunidades team at work 110

Figure 21 - Lucy with her mother and younger sister after presenting her final exam 115 


\section{Chapter 1 - Understanding Rural Women's Experiences: Context, Theory, and}

\section{Methodological Approach}

Expansion of higher education throughout Mexico has produced a new wave of

first-generation college students and professionals. Although women pursue opportunity through education in numbers equal to men nationwide, rural women often face significant logistic and cultural barriers compared to their male and urban peers. While young people and their families recognize the importance of higher education, a strong rural imaginary continues to influence decision-making and identity as rural youth and students (Meseguer Galván 2012). This tendency is especially true for rural young women whom families depend on to fulfill roles within the household that uphold community values and identity (Pérez Coeto Mateos and Flores Hernández 2007; Stephen 2005). Yet the emergence of higher education in rural areas such as those throughout the state of Oaxaca has also opened new opportunities for young women's professional development and new individual and community identities.

Rural women now find themselves between two worlds of possibilities: that of their mothers and grandmothers, primarily centered on the home and child-rearing, and the world of professionalism and academia. Instead of following previous generations' models of rural femininity, these women may choose to pursue professional development, where they encounter new individual and collective understandings of self. This thesis provides a window into the world of rural women who as first-generation college students seek new opportunities and identities through higher education. 
Specifically, I explore the tensions between the collective imaginary of rural Mexico and rural women's emerging sense of independence and self-determination in light of higher education's opportunities. These new opportunities lead to community formation around commonality of experience and egalitarian peer groups in addition to community relationships and roles. I situate this analysis within the context of the Universidad Tecnológica de los Valles Centrales de Oaxaca (UT), a technical university in semi-rural Oaxaca, Mexico. Through interviews and participant observation, I answer the following questions: (1) How is rural women's identity produced through policy, geography, and social influences? (2) In what ways do college women experience change in terms of family relationships and professional trajectories? and (3) How do changes in rural women's collective identity through professional development contribute to social movements for gender equality?

This thesis provides a broader examination of the implications of shifts in family and community trajectory on belonging and women's identity in Mexico, building on existing research addressing indigenous intercultural universities (Lebrato 2016a; Lehmann 2015; Ruiz López and Quiroz Lima 2014; Silva Laya and Rodríguez 2012), women's experiences in higher education (Delgado Ballesteros 2012; González Jiménez 2013; Howell 1999; Martínez Covarrubias 2006; Moshi 1998; Pérez Aguilar 2012; Villagómez Valdés and Sánchez González 2011), and indigenous students’ postsecondary education (Briseño Maas 2012; Flores-Crespo 2007; Manago 2012; Rea Ángeles 2011; Schmelkes 2013; Gallardo Vásquez 2007). Through this research, I aim to add to larger discussions regarding higher education in Latin America, women's roles, experiences, 
and interactions within institutions, and women's collectives as venues for societal transformation. In conclusion, I will offer recommendations for institutional policy that supports women's identity development, promotes gender equality, and encourages women's leadership. Attention to rural women's experiences is a key component of global initiatives for promoting gender equality.

\section{Socioeconomic and institutional context}

\section{Oaxaca, Mexico}

Located on the Southwest coast of Mexico, Oaxaca (see Figure 1) as a state is representative of other rural areas in Mexico and globally that experience significant outmigration and challenges to providing innovative education to meet local needs. With fifty-three percent of the population residing in communities of under 2,500 people (Instituto Nacional de Estadística y Geografía 2014), the state has historically experienced higher levels of poverty and economic marginalization than anywhere else in

Figure 1 - State of Oaxaca, Mexico

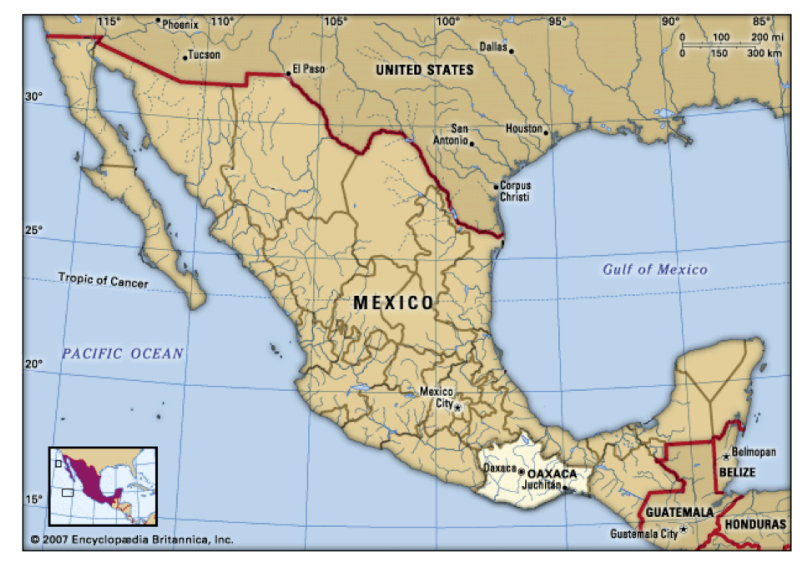

Source: Encyclopedia Britannica, 2015
Mexico besides its eastern neighbor, Chiapas. The recent United Nations for Development in Mexico Program (2014) nationwide analysis of health, education, and income shows that Oaxaca state has the highest number of communities 
with a low human development index rating (see Figure 22, Appendix A). Across additional indicators of poverty from access to electricity and indoor plumbing to dirt floors, Oaxaca consistently ranks well below the national average, as shown in Figure 2. Following a national pattern of spatialized urban/rural inequality, rural Oaxacans experience significantly higher levels of poverty than their urban counterparts (see Figure 23, Appendix A).

Despite the historic lack of economic resources and academic infrastructure, educational achievement at all levels has increased in Oaxaca in recent years. Since 2000,

Figure 2 - Indicators of poverty: Oaxacan household compared to national household average (2010)

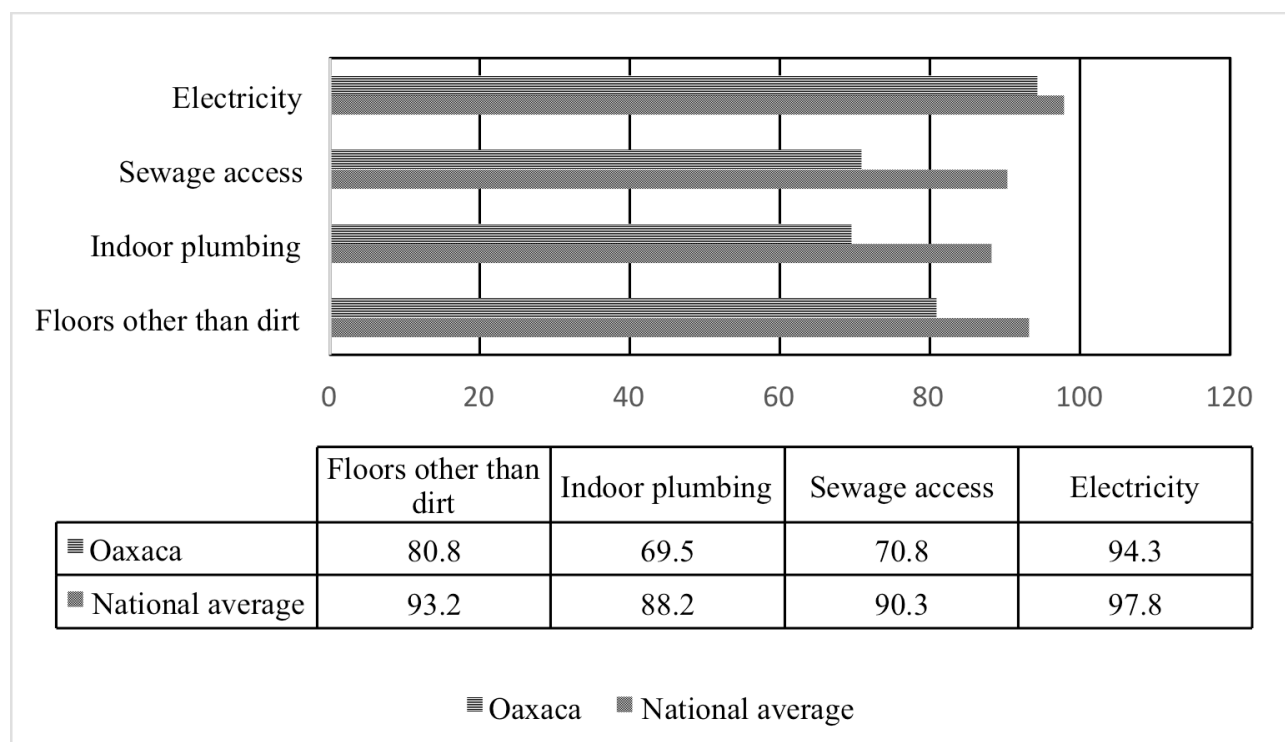

Source: Instituto Nacional de Estadísticas y Geografía 2010

the number of universities located throughout the state has expanded and facilitated increased enrollment in tertiary education. Paralleling this expansion, government grant programs have permitted greater access for low-income students. As Figure 3 
demonstrates, though average Oaxacan educational attainment lags behind the national average, women have surpassed men in completion of higher education, doubling in percentage between 2000 and 2010. Nevertheless, these numbers remain almost twenty

Figure 3 - Percent of population having completed higher education

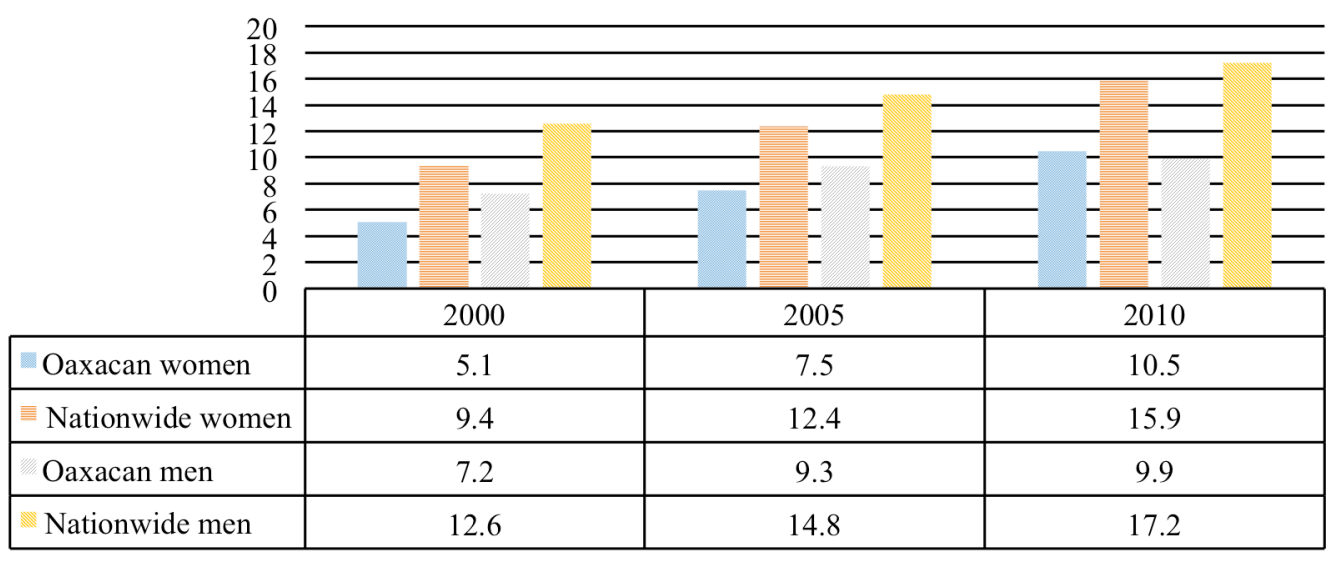

Source: Instituto Nacional de Estadísticas y Geografía 2005; 2010; 2015

percent lower than urban areas of the country.

$\underline{\text { San Pablo Huixtepec and the Universidad Tecnológica de los Valles Centrales de Oaxaca }}$

The Universidad Tecnológica de los Valles Centrales de Oaxaca (UT) (Technical University of the Central Valleys of Oaxaca) is located in the town San Pablo Huixtepec. Like other medium-sized Oaxacan communities, small businesses, agriculture, and migration to California sustain San Pablo's local economy. San Pablo's convenient location one hour from the state capital, Oaxaca de Juárez, and fifteen minutes from the district capital, Zimatlán de Alvarez, facilitates commuting for employment and 
education options. The convenient location to neighboring communities allows some students to live with their families and commute to campus. Other students from more distant communities throughout the Central Valleys and Sierra regions choose to rent rooms from families in San Pablo.

In 2009 the UT welcomed its first
Figure 4 - Universidad Tecnológica de los Valles Centrales de Oaxaca logo

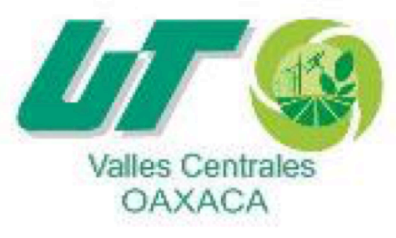

Source: Universidad Tecnológica de los Valles Centrales de Oaxaca cohort of students in the municipal government building in San Pablo Huixtepec. Since 2011, the UT has operated out of its own campus and has significantly expanded its infrastructure, programing, and student services. The university now enrolls over 1,200 students in four- and two-year degree programs in Gastronomy, Renewable Energies, Business Development and Innovation, Food Processes, Sustainable and Protected Agriculture, Information and Communication Systems Technology, and Mechatronics. Forty-nine percent of the student population self-identified as female ${ }^{1}$ in a recent university census, ${ }^{2}$ and 187 (17.1 percent) of the student population self-identified as indigenous, speaking nine different indigenous languages. ${ }^{3}$ Gastronomy and Business Development have the highest student enrollment and the most women of the majors on campus. Many more students are enrolled in two-year degree programs than four-year, as

\footnotetext{
${ }^{1}$ Only two options were available on the census: female and male.

${ }^{2}$ Not all students at the UT participated in the census, and not all majors are equally represented. Nevertheless, this is the closest approximation to data in enrollment numbers possible at this time.

${ }^{3}$ See Appendix A, Figure 24
} 
shown in Appendix A, Figure 25. ${ }^{4}$ These figures are significant in that they indicate high rates of student attrition; although the UT successfully attracts students to the institution, retaining them through completion of a four-year degree proves challenging. For example, by at least their third year of enrollment, more than half of women who begin the Business Development and Innovation degree drop out.

Figure 5 - Number of students in each program of study by gender

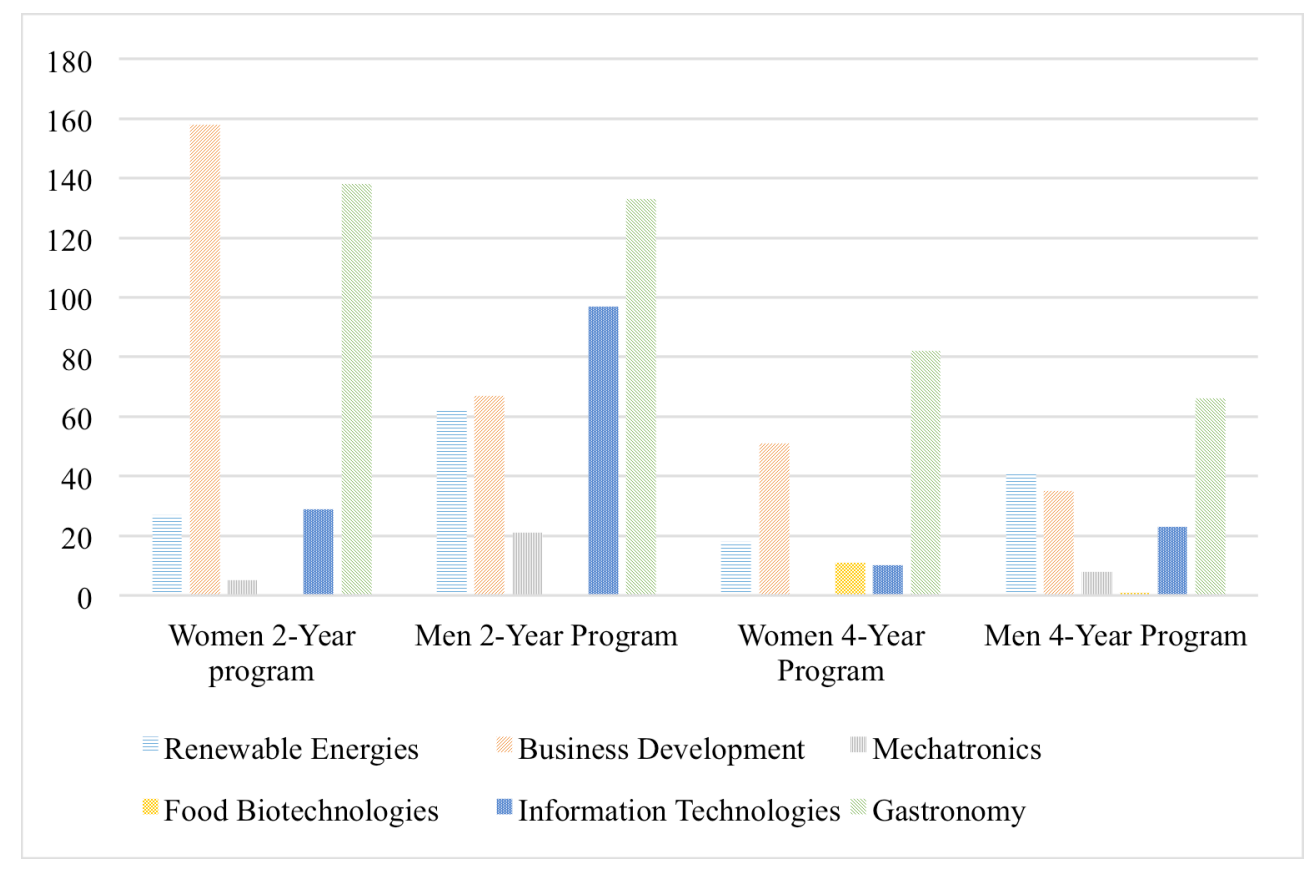

Source: Universidad Tecnológica de los Valles Centrales de Oaxaca 2016

The UT in San Pablo forms part of the Sistema de Universidades Tecnológicas (System of Technological Universities), a nationwide network of 104 federal institutions

${ }^{4}$ See also Appendix A, Figure 25 
in twenty-nine states (Universidad Tecnológica de los Valles Centrales de Oaxaca 2013) that began in 1991 (Flores Crespo 2009). Based in educational models adapted from French universities and colleges (Mazeran 2006), three goals drive the UT system: decentralization of higher education, university-business partnerships, and diversification of programs of study (Secretaria de Educación Pública 2008). Individual states and the federal government provide equal funding for each institution in addition to resources obtained from student tuition and fees (Secretaria de Educación Pública 2008). Each university's course offerings reflect regional needs, and short degree programs encourage students to enter the workforce as quickly as possible (Secretaria de Educación Pública 2008). The system measures success in terms of response to local economic demands, student retention and completion, and student incorporation into the labor market after graduating.

Nationally Technological Universities are located in communities or regions traditionally underserved in terms of access to higher education (Flores Crespo 2009). In fact, the Technological University network calls itself one of the "most equitable higher education institutions in the Mexican system" (Mazeran 2006, 13). The UT's website boasts that nationwide, thirty percent of students attending UTs would not otherwise have access to higher education (Universidad Tecnológica de los Valles Centrales de Oaxaca 2013). Previously economic and cultural hurdles prevented students - especially women from leaving their home communities to move to the city for access to a university. Oaxacan higher education policy has recognized this challenge. Over the past two decades, national policy focus on creating universities in rural regions (Mendoza Rojas 
2015) has resulted in eighty-eight universities throughout Oaxaca (as of 2012) that provide greater physical access to higher education opportunities ${ }^{5}$ (Coordinación General de Educación Media Superior y Superior, Ciencia y Tecnología 2012). Forty of these eighty-eight institutions form part of public higher education subsystems, Technological and Politech systems, and teachers' colleges. The remaining are private colleges. Individually small in size, in 2011 public and private universities throughout the state enrolled 44,623 and 12,860 students, respectively, at all levels, including graduate and post-graduate $^{6}$ (Coordinación General de Educación Media Superior y Superior, Ciencia y Tecnología 2012). This represents significant expansion of opportunity, as student enrollment more than doubled in Oaxaca between 2006 and 2012 (Mendoza Rojas 2015). Now sixteen of thirty total districts ${ }^{7}$ throughout Oaxaca have at least one higher education institution, although forty-five percent of all the universities are located in the Central Valley region within or near the capital city (Coordinación General de Educación Media Superior y Superior, Ciencia y Tecnología 2012). Nevertheless, expansion into rural regions throughout the state has meant many low-income students can remain living with their families while they study. Many UT students in San Pablo and other Technological Universities cite the universities' locations as a primary factor in their decision to study there (Flores Crespo 2009; Ramírez García 2012). As access to education continues expanding with more fields of study and institutions, more first-

\footnotetext{
${ }^{5}$ This number still lags behind the national average university to college-aged person ratio (Székely 2013).

${ }^{6}$ According to INEGI (2010) Oaxaca's total population of all ages is 3,801,962.

${ }^{7}$ Like counties
} 
generation, low-income, and indigenous college students will pursue higher education in places like San Pablo and the UT. This research thus represents a significant contribution to an emerging field of interest among higher education professionals working in Oaxaca and other rural areas of Mexico.

Students at the UT spend their university careers in cohorts of about twenty-five peers with whom they take all their classes and work on group projects through an intensive, full-time quarter system that encourages students to complete their degree program quickly. Advisors oversee student progress and organize extracurricular or "homeroom" activities. The required courses and curriculum are designed to emphasize practical experience and knowledge over theory; the UT famously boasts "setenta porciento práctico, treinta porciento teórico" ("seventy percent practice, thirty percent theory”) as its guiding principle (Secretaria de Educación Pública 2008). In Oaxaca, the strong community-based implementation of this curriculum model - in particular its

Figure 6 - Entrance to the Universidad Tecnológica de los Valles Centrales de Oaxaca

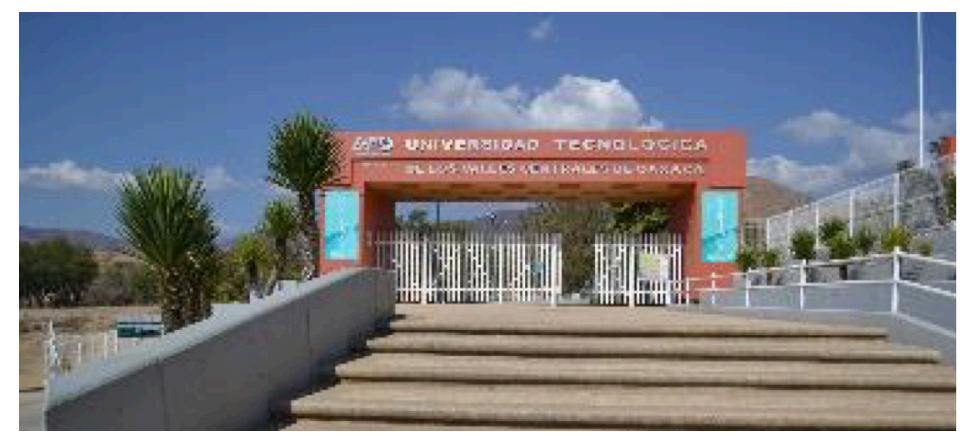

Source: Universidad Tecnológica de los Valles Centrales de Oaxaca 
scalability and linkages to international and local community businesses and organizations - has garnered the institution accolades from the state's Department of Education and the national higher education community. More detail about the UT's philosophical orientation and purpose will be provided in Chapter Two.

In 2014, the UT created the University Center for Women's Leadership (CMujer), a university-sponsored leadership development program for women. CMujer responds to the need for spaces within higher education for women to address and form community around issues like identity, family relationships, and community belonging. CMujer began by offering a series of workshops and volunteer opportunities and now provides a three-part certification course in leadership and entrepreneurship for young women, an international leadership development seminar in Portland, Oregon, and an annual women entrepreneurship conference. CMujer is the only program of its kind in the national system of Technological Universities or Oaxaca.

Anthropologists have criticized supposed "development" programs - such as CMujer or even the UT in general - among indigenous populations as ultimately damaging through furthering their dependence on neoliberal economics and opportunities (Hill 2001; Muehlmann 2009; Novo 2006). In Chapter Four, I posit that contrary to harmful and imposed neoliberal models of development, CMujer emerged from local priorities and addresses social and economic conditions based on women's perception of needs. My experiences have shown that this particular student population would otherwise be forming part of the migrant stream to the United States and urban Mexico. For example, when I taught a class in Sociocultural Formation in 2013, twenty-nine 
students in a class of thirty had at least one close relative working in the United States. Other students at the UT have themselves previously worked in the United States or previously considered migration as an option. In this way, the UT and programs like CMujer provide alternative pathways that, to quote one student, "help [their communities] suffer less." It is only reasonable then to recognize the existing interrelation between rural communities and neoliberal or capitalist interests and provide opportunities and tools for women and their communities to determine their own roles within the system or redefine and transform it to suit local needs and interests. Skill development, community building, and collective empowerment for gender equality through CMujer will be discussed at length in Chapter Four.

\section{Thesis Structure and Theoretical Outline}

This thesis seeks to understand how place, context, community, and family shape young women's identities, higher education experiences, and community belonging in rural Mexico. I employ a multidimensional lens to understand the social production of space and subjects in order to detail the myriad nuanced influences on the student experience within rural higher education. I structure my analysis around three complementary theoretical perspectives: Lefebvre's (1974) production of space, Anzaldúa's (1987) Borderlands, and Stephen's (2005) notions of community and individual identity grounded in ethnographic fieldwork in rural Oaxaca.

In Chapter Two, Producing Space and Identity in Rural Oaxaca, I unpack layers

of time, interpretations, interactions, ideologies, thoughts, feelings, emotions, words, and 
actions that socially produce rural Oaxaca and its emerging opportunities for higher education. Space, as Lefebvre (1974) has explained, is constructed throughout time and also in specific moments in time as layers of interwoven meaning build on top of one another. Expectations, experiences, policies, infrastructure, and historical events collide to produce both collective and individual understandings of both the physical space itself and the people inhabiting it. I approach my analysis through the three lenses Lefebvre (1974) proposes as components of space: spatial practice (physical space), representations of space (conceived or ideological space), and representational space (the spaces of dreams and possibility). First, I consider the spatial practices of rural Oaxaca and their implications for young women. I juxtapose this with the physical world of the Universidad Tecnológica de los Valles Centrales de Oaxaca (UT). I then contextualize these spaces within the representations of space the UT, using as examples institutional goals and discourse. I conclude by examining the spaces of representation - the lived experiences - of young women on campus. These three arenas of space inherently link to one another and produce an overlapping mosaic of rurality and rural women. Although juxtaposed in this chapter, I recognize the interconnectedness and mutual dependence of rural and urban spaces and people. Nevertheless, understanding the ways in which individuals view them as dichotomous within social spaces and policies remains useful for understanding rural women's experiences in higher education.

Lefebvre $(1974,87)$ describes space as fluid and organic, "traversed by myriad currents," and characterized by "great movements, vast rhythms, immense waves [that] all collide and interfere with one another." Within this space of ambiguity and 
interconnectedness, I incorporate Anzaldúa's (1987) Borderlands theory to examine the ways in which rural women simultaneously inhabit multiple spaces of representation. Anzaldúa's term nepantla describes experiences of those who live in-between or overlap with multiple geographical or ideological spaces and provides a lens for understanding diverse epistemologies that do not fit within dominant narratives. Although Anzaldúa (1987) applies her theory to the mestiza experience on the United States-Mexico border, in Chapter Three, The Profesionista's Borderlands: Family Belonging, Conflict, and Transformation, I extend Borderlands theory to the experiences of rural Oaxacan women who pursue higher education at the UT. As first-generation college students, these young women occupy a space in-between professionalism and higher education and the traditional ethos of rural Mexico. Through growth via conocimiento, time, and practice, the in-between, transformative, and unstable space of nepantla becomes home - a space of representation in itself. In Chapter Three I utilize the seven dialectical and iterative stages of conocimiento as a framework to detail women's process of identity transformation into profesionistas as they progress through university studies. In particular I draw on Stephen's (2005) ethnographic work to highlight gender and class in rural Oaxaca, Butler's (1988) performativity theory, Foucault's (1977) concept of dressage, Bourdieu's habitus (1977) and social capital (2011), and Holt's (2008) embodied social capital to explain rural women's process of identity transformation. I specifically focus on family and community relationship negotiation, including three principal areas of tension I have identified: socioeconomic mobility, generational ideologies about women's proper community and family role, and unfamiliarity with the 
student role and responsibilities. I conclude this chapter with an exploration of embodying, internalizing, and externalizing two simultaneous worlds, the work of living in the Borderlands.

In Chapter Four, Building Community in the Thirdspace: CMujer as Convergence and Transformation I detail the process of creating the University Center for Women's Leadership (CMujer), including the team members involved, motivations, goals, curriculum, and participant recruitment and selection. I include my role as an activist anthropologist (Hale 2008; Speed 2006) in the development and implementation of CMujer. I then present CMujer as a unique space of representation (Lefebvre 1974), a Thirdspace (Soja 1996). Using CMujer as a Thirdspace for transformation, women form a collective identity as nepantleras working toward common goals instead of relying on traditional kinship ties (Stephen 2005). I show that women's participation in new spaces of representation available in Oaxacan higher education promotes individual development in support of women's collective empowerment both within the university and broader, rural and multigenerational contexts.

Throughout this thesis, I rely on Stephen (2005) to highlight the intersection of gender, ethnicity, community, age, and class as it relates to women's public participation, involvement in cooperatives, and identity in relation to other community members. Additionally, Stephen's $(2005,10)$ research is helpful for pushing beyond understandings of gender as "women as differentiated from men" in order to examine gender's relationship to broader community and national economic, political, and cultural systems. I complement Stephen (2005) with other anthropological frameworks to understand 
women's identity formation as gendered subjects situated in particular class (Ortner 2006; Stephen 2005), material and spatial (Christie 2004; de Koning 2009; Stephen 2005), and relational (Brubaker and Cooper 2000) contexts.

Finally, in Chapter Five, Conclusions and Recommendations: ¡Pa'delante, Mujeres!, I conclude with a discussion of nepantla's implications for women's roles in rural communities and challenges to their incorporation back into community life. I also present recommendations for continued expansion of CMujer in support of rural women's leadership development. I recommend that CMujer lead campus initiatives to support indigenous women, create gender-based violence prevention programs, and retain alumnae in the CMujer community. Leveraging CMujer's transformational space for community building will support gender equality movements throughout rural Mexico.

\section{Methodological Approach: Confianza and the Role of the Researcher}

Participant Observation and Activist Anthropology

Before I carried out the individual and group interviews for this research during the months of July through September $2016^{8}$, I began establishing a professional relationship with the university administration, student body, and local academics and activists in 2011 as an undergraduate. I have spent about two-and-a-half years total living and working in Oaxaca, including two separate extended stays in 2011 and 2013 of six months and one year, respectively. Participant observation during this five-year period

\footnotetext{
${ }^{8}$ Internal Review Board permission was obtained through Portland State University for this fieldwork.
} 
has informed my analysis and created unique opportunities for access to institutional decision-making and student life. I carried out most of the participant observation during a three-month period in 2016 on the UT campus during staff meetings, informal chatting in the Outreach Department, classes, on-campus conferences and forums, and off-campus university-sponsored activities. Other observation opportunities occurred during car rides to and from campus, quick meet-ups for coffee, long, lingering dinners in downtown Oaxaca, while on lunch break on-campus, and marching through the streets of San Pablo Huixtepec on Independence Day.

Additionally, I am the Co-Founder of the University Center for Women's Leadership (CMujer) and have since established a nonprofit organization in Oregon, Women's International Leadership and Learning (WILL), that supports CMujer's work. Through this role, I have essentially become an extended part of the campus community. Some members of the administration and support staff are my close friends; we are in contact at least on a weekly basis, if not daily during periods of organizational planning and fundraising. Spradley $(1980,61)$ has termed this level of engagement "complete participation," whereby the researcher is already part of the community or landscape, what he terms an "ordinary participant." I have built a foundation of confianza between myself and the staff, administration, and student body. Confianza indicates feelings of both trust and confidence, an essential component of gathering accurate data and opening dialogue with the women and men who participated in this research (Dyrness 2008a, 2008b; Napolitano 2002).

Drawing on these relationships and confianza has facilitated my role as an activist 
anthropologist (Hale 2008; Speed 2006). Informed by Speed's (2006) critically engaged activist anthropology work in Chiapas, through my involvement with the UT I sought to further mutually defined goals with an anthropological lens. In doing so, like Speed (2006, 71), I was able to both make my "solidarity explicit" and "an overt commitment" to our shared goals of creating opportunity for women. Given that anthropological research has historically been fraught with uneven power dynamics between the researcher and subject, I sought to mitigate the potential for my research to act as data or information extraction by using the opportunity to conduct this research to inform and clarify the UT's goals and policies. This thesis provides testimony through the eyes of students to the necessity of women's support services on campus. Additionally, through this role as an activist anthropologist, I have used my skills and networks to support the development and implementation of essential student support services at the UT. This has required that I adjust to cultural and institutional particularities (Corbett et al 2016), a challenge necessitating patience from everyone involved in the collaboration.

\section{$\underline{\text { Interviews }}$}

I conducted semistructured interviews with a total of twenty-three female students and two male students from four different majors. Nine of these twenty-three women participated in two separate semistructured group interviews. Using semistructured "empathetic" interviews was important to allow students and faculty to describe on their own terms their context, thoughts, and feelings (Fontana and Frey 2008, 116). This

method also has the added benefit of providing space for participants to explore and 
process some of their experiences related to the topic (Johnson and Parry 2015; Rose 2016). I began each student interview by asking for their age, year of studies, community

Figure 7 - Interviewees' parents' highest level of schooling achieved

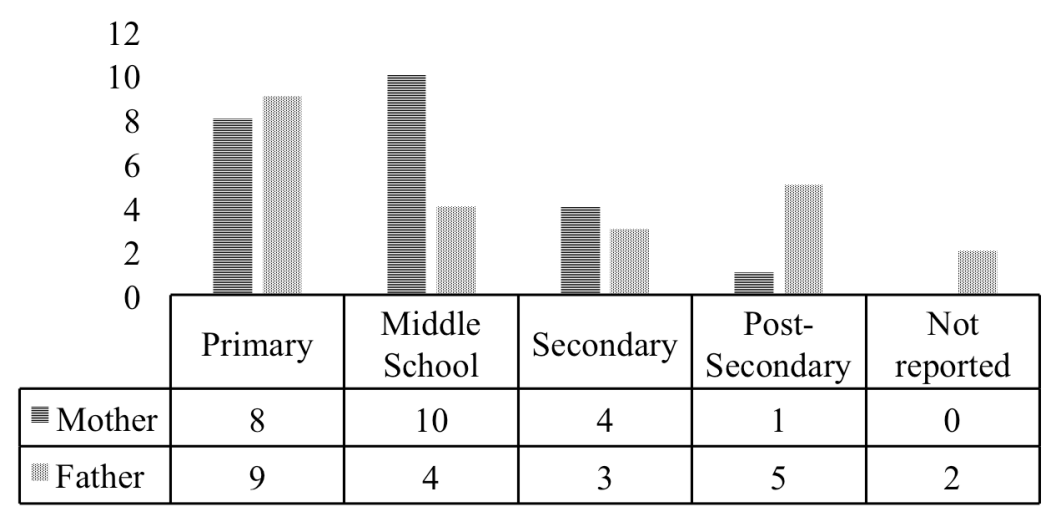

of origin and parental occupation and educational attainment. I interviewed both lower and upper division students. Students ranged in age between nineteen and twenty-three, with outliers at eighteen, twenty-five, and twenty-seven. Fourteen students identified as having grown up in a rural community, five in an urban area, and four in a semi-rural setting. Figure 7 shows the educational attainment of student participants' parents as reported by students. In addition, seven faculty and staff members participated in semistructured interviews, including four Department Chairs (Business Development and Innovation, Food Processes, Gastronomy, and Foreign Languages), the on-campus medic, and two professors. Interviewing a variety of people on campus provided insight into the various facets of campus life and the opportunity to compare distinct perspectives. I conducted all of the individual and group interviews with students, faculty, and staff in Spanish and digitally recorded each one. 
Ethnographic Vignette and Memes

In addition to a set list of open-ended questions, I employed two complementary techniques to provoke dialogue during interviews and focus groups with students: an ethnographic vignette (see Appendix B) and two memes (see Figure 26 and Figure 27, Appendix B). I wrote the ethnographic vignette based on previous research and oral histories of women students at the UT. I asked students to read the vignette and respond to a series of questions. As Manago (2011) explains, this method not only creates a point of departure for conversation grounded in local understandings, but also provides ample data for qualitative analysis.

Similarly, I presented each of the two memes, invited comment, and followed with a series of questions regarding each person's experience as it related to the theme addressed in the image. I downloaded the images from an unofficial Facebook page with 5,580 followers administered by anonymous UT students called Memes UT. I chose the memes because of their popularity on the Facebook page, their relevance to themes of gender and space on campus, and the role of memes as cultural signifiers (Dawkins 1976). The first meme depicts street harassment toward women in the Business Development Department, and the other mocks male sexuality in the Gastronomy Department. The Business Development meme received 117 "likes" on Facebook and was shared four times, and the Gastronomy meme received eighty-six "likes" and was shared twelve times. While these images do not represent the UT administration's intended goals for the student experience, they bring to the forefront underlying tensions related to gender and sexuality on campus. The use and popularity of memes to identify 
in-group and out-group through humor (Miltner 2014) and thus the unique applicability to the UT context solicited immediate reactions from interview participants. About half of the students I interviewed had seen the memes on Facebook already.

\section{Data Analysis}

I conducted and transcribed all interviews and focus groups in Spanish. I then coded all qualitative data (i.e., interviews, focus groups, and field notes) using the following themes that emerged from the data itself (Bernard 2011): challenges in higher education; family and community relationships; thoughts, feelings, and ideas about the university; thoughts, feelings, and ideas about rural communities; thoughts, feelings, and ideas about urban communities; thoughts, feelings, and ideas about the University Center for Women's Leadership; reflexive descriptions of self; and descriptions of future self and opportunities.

\section{$\underline{\text { Recruitment }}$}

I recruited participants using a sampling method based on personal contacts and the advice of key informants like Department Chairs and faculty mentors. I met with Department Chairs individually, explained the purpose of my research project and the interviews, and each Chair recommended either particular students or professors in their department who could provide better recommendations for interview participants. I followed up with individual professors who then could identify students they thought would either contribute a unique perspective to the research or happened to be available and interested in participating. I specifically requested professors to think of the diversity 
of students in their cohorts including women and men from rural and urban areas and indigenous communities. On two occasions, a professor introduced me to cohorts of students during class, and I invited them to participate if they were interested. Three students volunteered through this method.

Students were eligible for participation throughout any point in their studies and without consideration for family or socioeconomic background or community of origin. I knew some of the students already and had previously collaborated with all of the faculty members who participated. This made identifying potential participants a relatively easy task. With some interviewees I had already informally discussed issues of gender and community, so conversation flowed naturally and casually.

Although students may have felt pressured to participate at the request of their professors, I got the sense they were mostly curious about the research and, for those who did not already know me, my presence on campus. Women who participate in CMujer likely felt some amount pressure to participate given my role within the organization. Based on comments, photographs, and conversations shared on social media and group chats with CMujer participants, however, the information women shared with me varies little from their public representations of their experiences. I obtained informed consent from each student who participated, fully explained their rights within the research study, and provided multiple opportunities and space for them to ask questions of me, both before and after the interviews. Interestingly, my closest friends on campus seemed to feel the least amount of pressure to participate in the study: I asked on a couple of occasions if we could make time for a recorded interview, but when they seemed 
uninterested, I did not pursue the topic further.

Positionality

In my fieldwork and analysis, I have practiced reflexivity in terms of my role as an outsider to Oaxacan culture and society and yet another white anthropologist working in Oaxaca. Following advice and guidance from mentors, I tread lightly and took time and space to discuss and think about my presence on campus and the specific influence my work has by virtue of showing up year after year to discuss gender equality and women's issues. I also draw on Mohanty's $(2004,3)$ notion of "feminist solidarity" to frame my approach to this research. I acknowledge the reality and conflicts caused by borders "between and through nations, races, classes, sexualities, religions, and disabilities," and as a feminist activist I "envision change and social justice work across these lines of demarcation and division." As I describe in Chapter Four, providing and facilitating international education opportunities is one way I have implemented this vision.

My social position as a gringa nevertheless undoubtedly influenced students' and professors' interactions with me. This became apparent especially when discussing topics related to international opportunities and gender in different contexts. The irony of my freedom to travel to Mexico and students' restricted access to United States' travel visas, especially in light of the 2016 United States presidential election, came up in conversations with interviewees. Students also asked questions about my perception of gender issues in Mexico and norms and customs in the United States, wondering if I judge them or if perhaps I should be judged, too. I openly discussed differences and 
similarities with students, creating space for dialogue about the issues explored in this thesis.

Additionally, following the example of Behar (1996), the exploration of Borderlands and shifting identities has been a personal experience for me as I have created and recreated my identity during my undergraduate and graduate education as a first-generation college student. Although I do not explicitly employ autoethnographic methods like Behar (1996) or testimonio (Delgado Bernal, Burciaga, and Flores Carmona 2012), I have felt deeply connected to the women introduced in the following chapters and share common experiences. I invite the readers of this work to reflect on the ways they too are nepantleras in physical and ideological Borderlands. 


\section{Chapter 2 - Producing Space and Identity in Rural Oaxaca}

Lucy invited me to join her and her family for a meal in San Garabato, ${ }^{9}$ a ranchería ${ }^{10}$ she described as "being outside of a town that's outside of a town." To get there, we met early one morning by a park in Oaxaca City. As we boarded the van that would take us to our first stop, Miahuatlán, we drank atole ${ }^{11}$ and chatted about what to expect in Garabato. Mole ${ }^{12}$. Lots of mole. Her older cousins just got back from spending several years working in Los Cabos, and with the dual purpose of reconnecting with the community and celebrating their oldest son's kindergarten graduation, they hosted a mole meal for their family. Excited as always by the prospect of fresh tortillas, Lucy and I wound our way up through the mountains and out of the valley, eventually piling into the back of a pickup with campesinos $^{13}$ carrying repurposed Tehuacán egg boxes and sturdy plastic bags filled with provisions. The pickup came to an abrupt halt along the two-lane highway, the driver shouted something out the window, and we hopped out to wait for a mototaxi that would take us the rest of the way.

As we sat along the highway on a bench fashioned out of two wood planks on top of buckets, señores and señoras greeted each other with a "buenos días" (good morning) and a head nod as they passed. The high elevation meant the air was crisp but refreshing; the señoras pulled their shawls tight around their shoulders, one hand extended

\footnotetext{
${ }^{9}$ Name changed

${ }^{10}$ A small, very rural community outside of the primary municipalities

${ }^{11}$ A hot, corn-based drink

${ }^{12}$ Traditional dish made of spices served like a sauce, usually over chicken

${ }^{13}$ Farmers
} 
downward to hold a child's wrist as they walked. The mototaxi driver pulled up to the stop, and Lucy negotiated the price for a ride to Garabato. We climbed in back, took off up the highway, and then pulled off where the pavement turned to mud with deep potholes. A sign along the roadway indicated we were a few kilometers from our destination. We held onto the metal frame of the mototaxi for balance as we bounced through the ruts in the road. Lucy's task was to remember where her aunt's house was. Amidst the trees and cornfields, she was concerned she would not recognize the turn off, but no sooner was she wondering if we had passed the house than her cousin appeared over a mound to the left. Lucy was relieved, and we hopped out of the taxi.

The family heard us coming up the hill all the way from the house. Since they expected our arrival some time that morning and very few vehicles pass by, Lucy's cousin was sure we had arrived and hustled up the hill to greet us along the road. The family's home was tucked below the roadway in the forest. We followed Lucy's cousin, greeted the men leaning up against an old truck in the driveway, and waved at the young boys who dangled out the back with wide eyes and dusty hands and faces. All the women were huddled around a giant pot of mole under the covered outdoor cooking area by the woodpile. One of the older women used a giant wooden spoon to stir the thick black sauce while she shooed away chickens that clucked too close to the food. Everyone greeted us warmly as we were ushered into the main kitchen building.

The home consisted of four separate one-room buildings. The kitchen walls were 
made of vertical wooden planks. It had a dirt floor, and there was a comal ${ }^{14}$ inside. Firewood heated the comal, requiring constant supervision. The young wife of one of Lucy's other cousins, Emma, was making dozens of tortillas. Her three-year-old daughter ran around, tripping over the door frame and dips in the dirt floor, then wandered too close to the fire until another cousin swooped her up and fed her bread and Coca Cola. Emma herself was only nineteen. I watched her, silently marveling at the ease of her tortilla making and parenting. When a chicken wandered inside the room, the little girl would chase it out, hands outstretched trying to catch it by the tail feathers. Emma calmly focused on her tortillas. She would pat the masa into rounded mounds, align the round plastic sheets on the press, raise to her tiptoes to put her weight onto the handle while she pressed down, lift the press lid, flip the tortilla over, press again, peel the plastic protector off, balance the thin masa on her hand, peel off the other sheet of plastic, and gently lay it on top of the hot comal. She tended to the other cooking tortillas, patting them down when they inflated, flipping them over quickly and expertly, and repeated this process over and over and over.

Although today was a special celebration, the routine really did not vary from other ordinary days in the ranchería. The men carried shotguns and left to hunt game and search for mushrooms. The women cared for the children and prepared meals. El Chavo del Ocho played in another one-room building where the television, table, and one bed were clustered together. There was no cell phone service in Garabato. Lucy and I looked at each other and sipped our sugary coffee out of bowls. Emma was easy to chat with.

\footnotetext{
${ }^{14}$ Smooth, clay surface traditionally used for cooking corn tortillas
} 
Lucy asked questions about the family in Garabato, and Emma recounted the latest news, including her daughter's health problems, and all the details of what different relatives had been up to recently.

I asked if there was anything we could help with to get the meal ready, and Emma responded with a curious laugh, "Do you know how to make tortillas?" One of the other cousins waited for the response that everyone already knew: no. They giggled. I turned to Lucy, “Tú pues?” (Do you?). She had to admit that she did not know how to either. Unlike for foreigners like me, tortilla making ability carries space and class connotations for Oaxacan women.

Lucy is acutely aware of the difference in her life as a college student and the life

Figure 8 - Me unsuccessfully making tortillas in Emma's kitchen

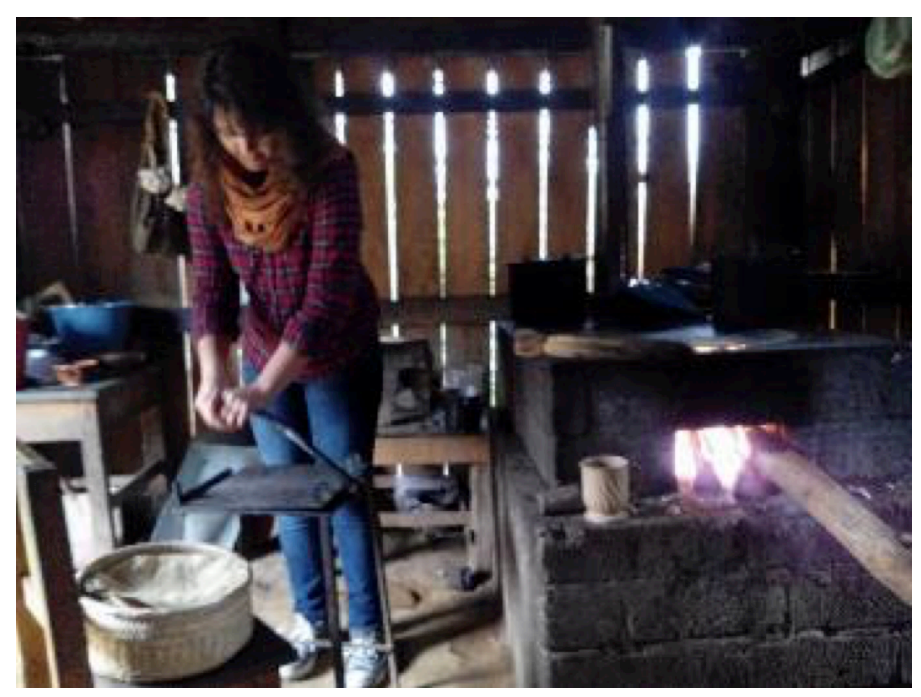

Photo taken by Lucy of her cousins like Emma in Garabato. She grew up in a house built on land south of Oaxaca City by the fork in the highway that leads either to the UT and eventually the coast or to the Miahuatlán region. Both her mom and dad, however, are from Garabato, and many of Lucy's relatives remain living there,

including her grandparents. There is an elementary and primary school in Garabato, but 
going to high school or college would have meant moving to Miahuatlán. Emma's parents lived up the hill on the other edge of the ranchería. She had been living here at Lucy's family's home since she and her husband got married shortly before their threeyear-old was born. This meant that Emma's job was to support the household with cooking, cleaning, child-rearing, and food production. I asked Lucy if she felt like she was missing out. She quickly answered with a short "no" and a sigh.

In this chapter, I analyze the social production of rurality - and, consequently, rural women like Emma - and how higher education contrasts with and builds on rural identity. I apply Lefebvrian theory in order to understand women's processes of identity formation within the production of rural and institutional spaces, operationalizing production beyond an understanding of materiality to include mental processes in addition to the physical world (Elden 2004). The material conditions of space and the collective, social understandings of space are produced via "social forces" (Elden 2004, 184), and the creation of space "is, in fact, a process" (Lefebvre 1974, 34). Lefebvre identifies three dialectical realms in which space is produced: spatial practices (the perceived, physical space), representations of space (conceived and ideological space), and spaces of representation (lived space). Each of Lefebvre's (1974) three spaces interact with one another, drawing on historical representations and creating constantly evolving understandings of rural space and rural women's pursuit of educational opportunities. The interconnectedness of rural and urban interactions creates fluidity and introduces elements of each space into statewide, national, and global trends and policies. Physical environments both shape and are shaped by social interactions. Spatial 
practice represents the physical layout of the world and is produced through "dialectical interaction" with society's space (Lefebvre 1974, 38). Physical space and practices within it "structure lived reality" (Merrifield 2006, 110), co-creating conditions for humanmaterial interactions. In order to understand this space, I discuss how materiality of the home, kitchenspace, and community shapes subjects, focusing on rural women's daily interactions with the physical world. I then situate young women within the context of the UT to explore and contrast their interactions with the space of higher education.

Next, I analyze the UT's goals as they relate to student identity development and broader understandings of rural Oaxacan identity. These representations of space, or the conceived space, are dominant ideologies proposed by "technocrats" who seek to propagate hegemonic discourses (Lefebvre 1974). Merrifield $(2006,109)$ describes this space as "in the head rather than in the body," reminding us that "ideology, power, and knowledge lurk within its representation." This construction of space sets the dominant agenda and delineates boundaries through policy and regulation. I draw on a public speech by the university President, the UT's motto, and internationalization efforts as specific examples of higher education's representations of space.

Finally, spaces of representation are women's directly lived interactions, feelings, and dreams within everyday life. These human experiences move through given spatial practices, interacting with, appropriating, and constructing it through "dialectical interaction[s]" (Lefebvre 1974, 38). Contrary to representations of space, spaces of representation are "felt more than thought," "alive," "elusive," and "essentially qualitative, fluid, and dynamic," "embrac[ing] the loci of passion [and] action" 
(Merrifield 2006, 110). As I show in this chapter, rural women's spaces of representation at the UT are often initially defined in contrast to urban understandings of rurality. Rural women find commonality with students from similar geographic and class backgrounds, eventually recreating and redefining the meaning of rural femininity through their educational aspirations. Understanding these processes contextualizes the spaces in which rural women connect with others, eventually embracing dual identities, as I discuss in Chapter Three.

Spatial Practices: Contrasting Kitchenspaces in Rural Oaxaca

Lefebvre's (1974) trialectics of space mutually produce and reinforce one another within historical contexts. Spatial practices weave through representations of space and spaces of representation, but physical space exists before subjects arrive to socialize it and modify its meanings (Lefebvre 1974). This preexistence influences the production of social space by "condition[ing] the subject's presence, action and discourse, his [sic] competence and performance" (Lefebvre 1974, 57). The textures within physical space produce variations across social groups. Similarly, Appadurai (1996) explains that locality is socially produced through both material culture and particular, small-scale spatial arrangements, which in turn produce localized subjects. The work of appropriating place and land as autochthonous space is part of a larger process of creating local knowledge; this local knowledge is at its root the knowledge of how to "produce and reproduce locality under conditions of anxiety and entropy, social wear and flux" (Appadurai 1996, 210). 
Women in rural Oaxaca commonly experience spatial practices (Lefebvre 1974) and Appadurai's (1996) production of locality vis-a-vis the space of the home. For women like Emma, described above, fulfilling her role at home as wife and mother under the supervision of her mother-in-law is an important component of performed femininity (de León Torres 2010; Stephen 2005). For others, such as Lupe, ${ }^{15}$ a Business Development student from a Zapotec community in the Tlacolula Valley, the "mentality

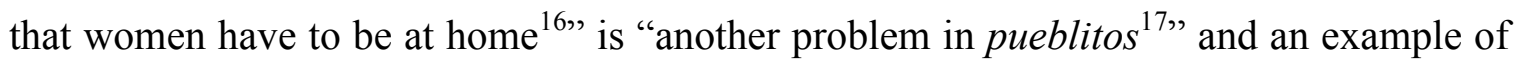
the challenges to education and professional opportunities she has faced. I asked what her life would be like if she had decided to not pursue higher education. Lupe laughed nervously, shook her head, and recounted her experiences of feeling enclosed in her home with decisive hand gestures on the table, delineating the separation between her home and the city. She had a serious look in her eyes, conveying the reality of the life she would be living:

Your mentality would still be really closed. You'd be there in that same... you'd be like just jailed in your house! You wouldn't have freedom to go out, see different things because like I was saying before like when I was in middle school I just went from my house to school, and I didn't even come to Oaxaca. I hadn't been to downtown Oaxaca because I was just in my pueblito. And if I left it was with my family but never alone.

\footnotetext{
${ }^{15}$ Name changed to protect Lupe's privacy

${ }^{16}$ I translated all direct quotes from Spanish to English based on transcriptions from recorded interviews.

${ }^{17}$ Little towns or villages
} 


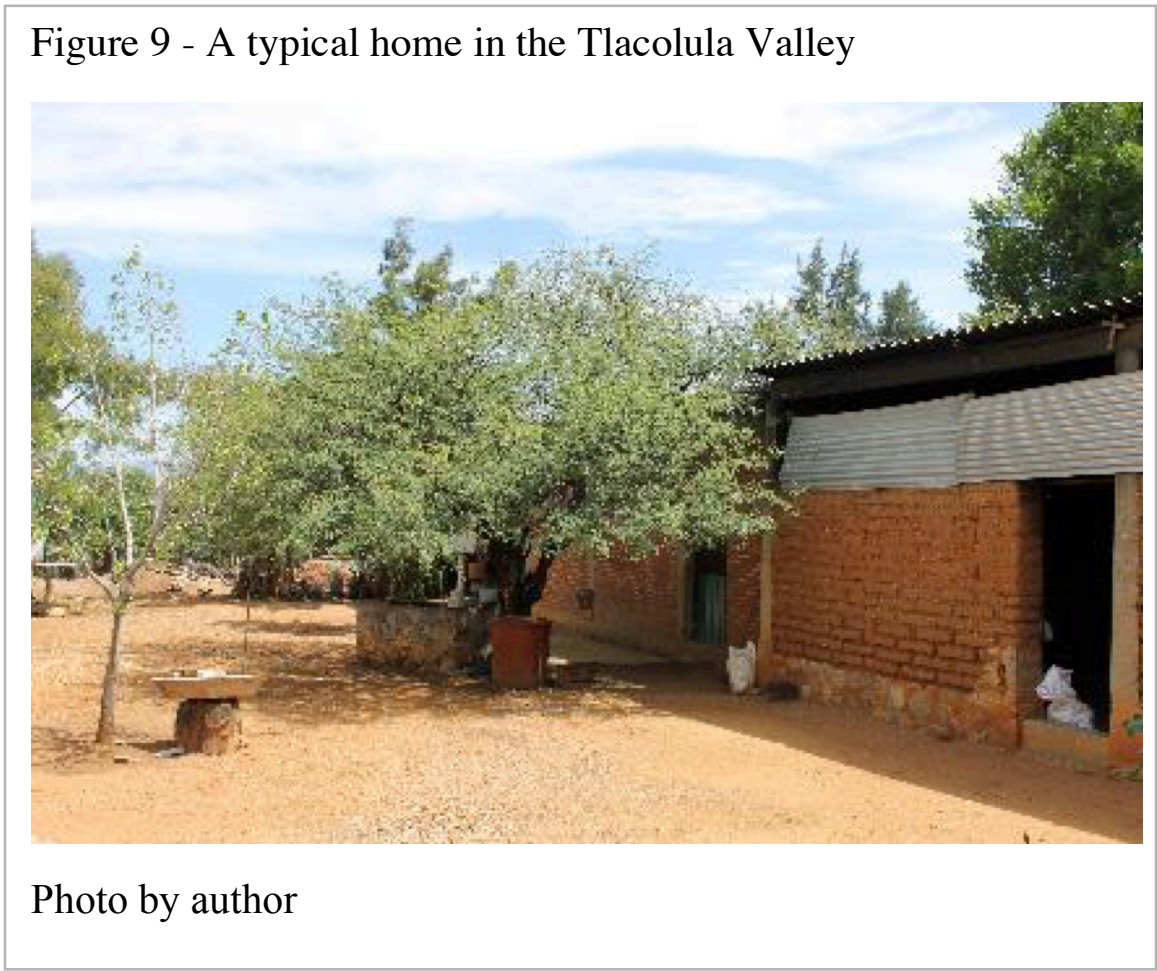

Another student, Esperanza, from a similar community outside of Miahuatlán in the Sierra Sur who now majors in Gastronomy, echoed Lupe's thoughts:

What would my life be like if I didn't study? I would be in my pueblo. Maybe I would already have a kid. I would be taking care of the house... cleaning, taking care of the boy or girl, and my husband would be out of state... For the people who live in my pueblo, the only thing is to get married, have kids, go to the fields, bring the firewood, cook, take care of the baby; your husband is away.

Lupe's and Esperanza's assessment of their situation is consistent with research across Mexico that emphasizes the role of the kitchen space in household production activities (Manago 2012; Pérez 2014; Stephen 2005). Pérez (2014, 133) describes the kitchen as not only a "focal point of household life" but the "center of a domestic logic that organizes social space." Thus the kitchen and home is more than its materiality and physical space; the logic surrounding the kitchen - its representation of space via 
symbolism and importance to community life and lifecycle recreation (Lefebvre 1974) shapes subjects like Emma. Kitchen and home space as a focal point exemplifies spatial practices as the combination of "the everyday" and "everydayness," together signifying both the "repetitive nature of everyday life" and the insertion of "daily life into modernity" (Elden 2004, 112). Furthermore, Lupe and Esperanza's projections of their alternative lives in their pueblos echoes how Lefebvre positions the role of bodies within spatial practices: "bodies...produce space and produce themselves, along with their motions, according to the laws of space" (Lefebvre 1974, 171).

Spatial practices additionally manifest through food itself. As illustrated above in the exchange between Lucy, myself, and Emma, Lucy's and my inability to make tortillas on the comal signified something much larger about who we are, and especially who Lucy is, even though she is just one generation removed from the rural femininity and its associated tortilla expertise. Particularly in Oaxaca and rural areas of Mexico, the tortilla and corn-based foods carry a "symbolic load" (Lind and Barham 2004, 47) that incorporates historical meanings (Pilcher 2005) and "embod[ies] the tensions of...cultural politics" (Lind and Barham 2004, 52) into the logic of home space reproduction. Drawing on the kitchen and home space logic as an epistemology, women become "subject[s] in whom lived [space], perceived and conceived (known [space]) come together within a spatial practice" (Lefebvre 1974, 230). Everydayness and everyday spatial practices inform local knowledge about rural communities and rural women. Within rural spatial practices and localized knowledge about the home - like food preparation and household maintenance activities - rural women are recognized and 
reaffirmed (Appadurai 1996).

Figure 10 - A UT students' mother polishes her metate and metlapil, the tools used for grinding corn into masa for tortillas, with pumice stone in her kitchen

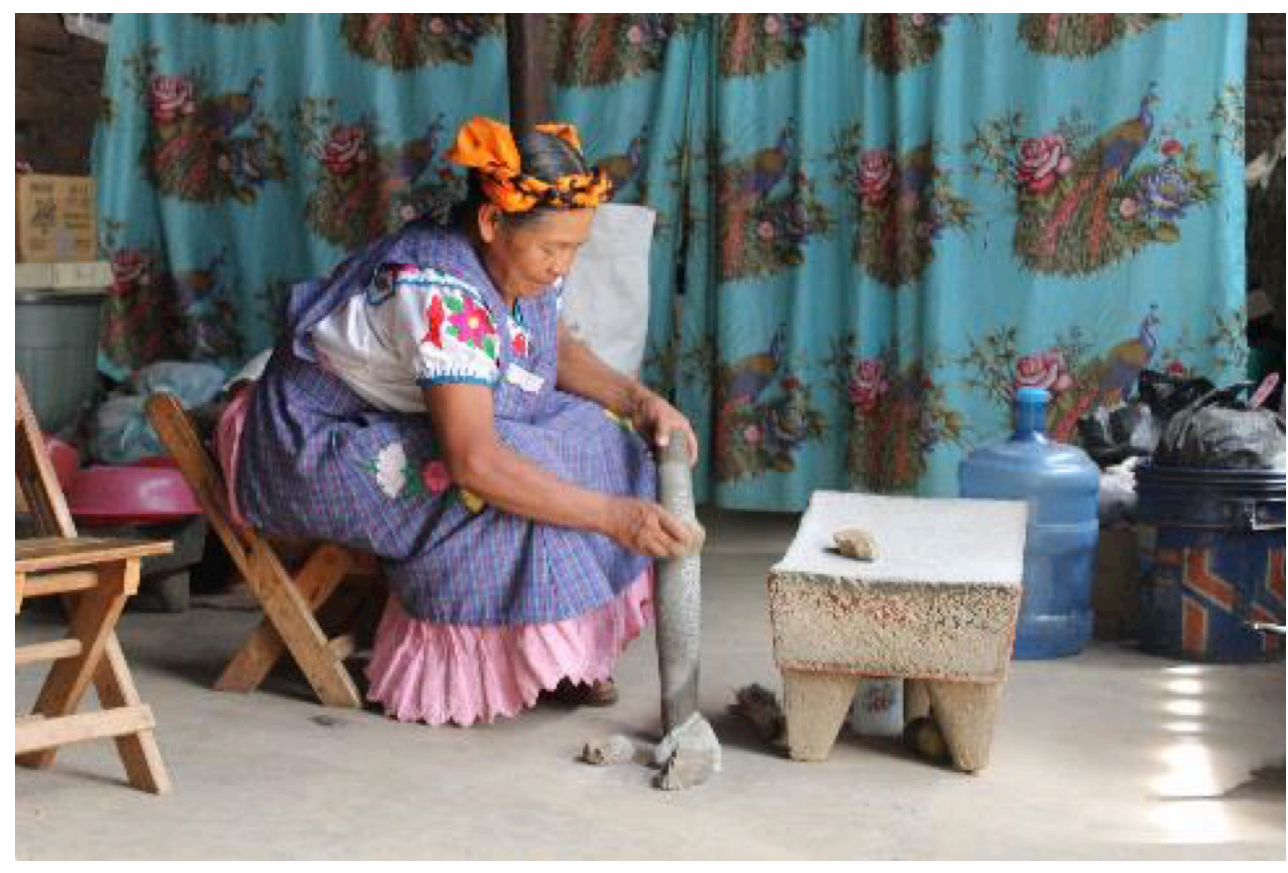

Photo by author

In contrast, the UT and institutions of higher education in rural Oaxaca produce subjects through material conditions and spatial practices that appear to be a world away from communities like Garabato or Lupe and Esperanza's hometowns. The Gastronomy Department highlights this difference. Students come to class prepared to work in white, double-breasted jackets and the tall toque blanche typical of chefs internationally. Three commercial kitchens line the South wall of the Gastronomy building, equipped with new, shiny stainless steel stoves, ovens, countertops, and food preparation supplies. Students hustle back and forth from the kitchens and the presentation area in the main open area of the building carrying plated dishes to their professors. In the main area of the 
Gastronomy building sits a bar for serving cocktails and specialty drinks. According to Lefebvre $(1974,230)$, these distinct and particular "qualities of space, not...qualities embedded in space" - such as industrial and professional grade kitchen supplies "repose upon specific spatial bases." At the UT, the Gastronomy Department as a spatial base contrasts with the home and kitchen space to which rural women are accustomed.

For

Figure 11 - Students working in the Gastronomy kitchens at the UT

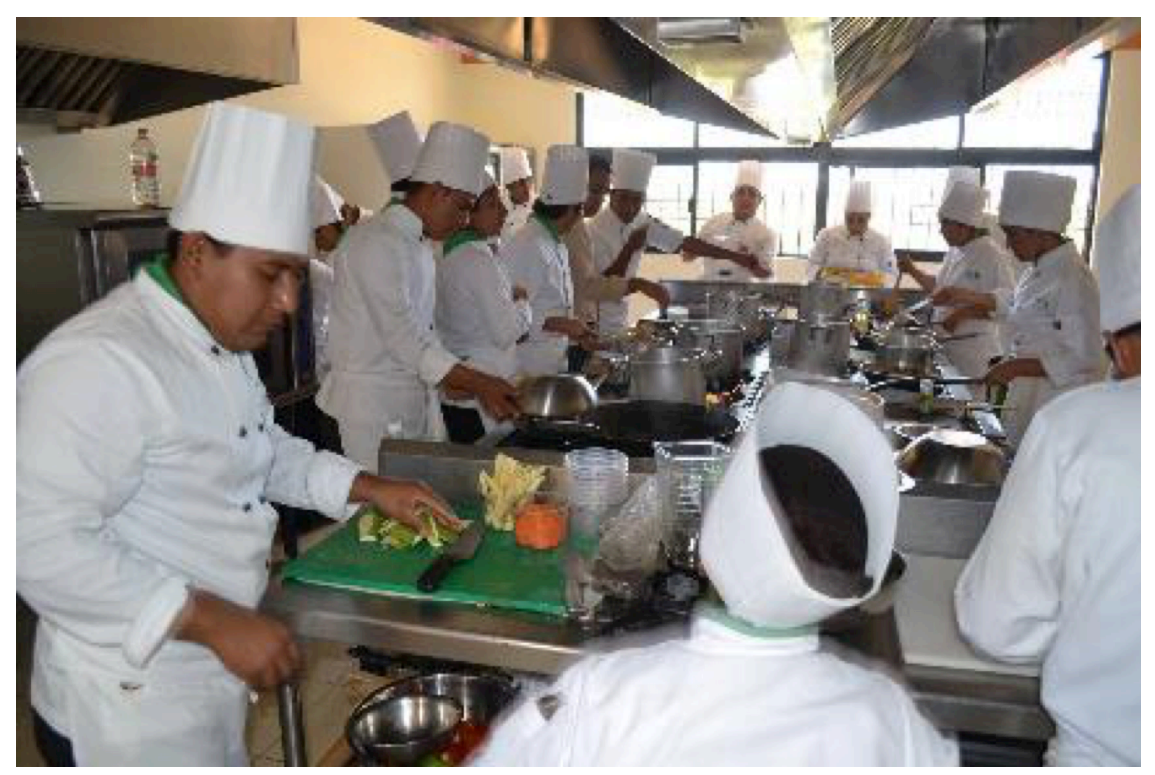

Photo by author
Esperanza, this spatial base, the professional kitchen equipment, and her chef's uniform represented excitement and a challenge. I asked her how

she had imagined herself as a college student. "First," she replied, "I was excited about the uniform" because of the level of professionalism and proficiency it represented. Using industrial kitchen equipment, however, was at first a challenge for Esperanza:

Well at first it was difficult because I wasn't familiar with the vents where the smoke goes out. I didn't know how to turn them on. I didn't know how to turn on an oven. The only thing I had used was a fridge. I was familiar with the... the 
burners, but we only use the comal, firewood, and well here when I asked, "How does one light the stove?" And like, “Ay, you don't know this?" Well I don't know! That's why I ask.

In contrast to this challenge, the UT has incorporated elements of Esperanza's background and traditional culinary knowledge into the Gastronomy curriculum, evidenced by the comal and clay oven outside of the main industrial kitchens. Chef David, the Department Chair of the Gastronomy Department, explained that the department's goal is to create a fusion between modern techniques using industrial kitchens while incorporating elements of Oaxaca's rich culinary heritage. I interviewed him in the kitchen area of the department. "For example this is the industrial kitchen," he waved his arm in the direction of where all the students were working,

but in the storage area we have clay pots, [and] we use them because also tomorrow when [the students] enter the labor force and they get a job and say, "No, I can't make mole unless I have a wood oven and a clay pot," I mean no way. They have to adapt to what there is.

As Weiss (2011) shows in his application of Lefebvrian theory to localized food production in North Carolina, particular spatial and classed processes ultimately influence consumer outcomes. Similarly, in the UT's Gastronomy Department, spatial practices like using clay pots and the comal teach students how to professionalize rural kitchen practices for middle and upper class Oaxacans and tourists. This blending of tradition and innovation is important to students like Esperanza who see elements of their home community spatial practices - like clay pots, traditional cuisine, and the landscape - reflected in the university. At the same time, they are able to learn new recipes and become professionals with theoretical foundations in international cuisine. 
Esperanza gave me a tour of the campus, telling me stories and sharing her opinions along the way. She explained:

When I came for the first time to visit and look with my dad, I was interested in the kitchen. Like I really wanted to go into the kitchen. I thought, "What must it feel like to work in a kitchen where you work with a stove and you have to turn on the stove and you put your pan there to cook?" Because in contrast there [in my community] it's like starting the fire and setting up the firewood...You have to have gone to get the firewood, and what if it doesn't want to light because it's wet? It's falling, you're inhaling smoke, and here it's very different. It's a place I like to be.

Esperanza's contrast between her home kitchen and the UT Gastronomy Department highlights how "the whole" of a lived or conceived experience "is located within a spatial practice" (Lefebvre 1974, 369). Subjective feelings and ideas associated with objects (stoves and pans or a fire and firewood) both influence and are influenced by the spatial practices within the space - in this, case kitchens. Removed from the everydayness of rural life, Esperanza recognizes the UT as "a place [she] like[s] to be." By understanding pans and stainless steel stoves as symbolic markers and signs, the UT in contrast to her home is "made special by symbolic means as desirable [versus] undesirable" (Lefebvre 1974, 288). Furthermore, the novelty and professionalism of the UT kitchen - a space decidedly not "everyday" in nature for rural women as a whole highlights how the everydayness of Emma's comal, tortilla making, or firewood become "trivialized spaces of everyday life, actions and signs" (Lefebvre 1974, 288) despite their symbolic significance (Lind and Barham 2004). The availability of a comal and wood burning oven within the Gastronomy Department, however, provides a bridge between rural and academic spatial practices. In this way, students may see their experiences and 
lives reflected on campus and draw on them when necessary to teach other students tortilla making or prepare traditional foods.

The UT's campus in general also acts as a symbolic marker for rural spatial practices. After Esperanza mentioned her father had came to visit campus, I asked her about his opinion of the space:

My dad says the university is in a very good location. Like my parents, I love the trees. I love them. My house is full of trees, and my dad takes care of them and so he told me, "I think you're going to be well here." And what my dad is really interested in is that I breathe fresh air. (She laughs.) That's like what he said to me because in the city there is so much pollution...You can't compare it with being in a pueblo or in the fields...So he said, "Well, there are a lot of trees, and I like the place," he said, "Well if you want you can stay to study here." And I said, "Yeah, I want to."

Despite the seemingly dramatic shift in spatial practices, the physical space both presents new opportunities for women to craft their identities in spaces outside of the home and harkens back to familiar, known, and valued categories through the landscape and materials. For example, the UT's location on a hillside overlooking the valley, fields, and hills in the distance does not just connect the university community with rurality; as Esperanza's father noted, with references to "fresh air" and trees the university is both located in a rural milieu and intentionally cultivates the feeling.

The campus contrasts with common urban environments that "imitate...signs of nature or of the natural realm," as Lefebvre $(1974,376)$ argues often occurs. For example, when each student graduates, they plant a tree on campus. This symbolic act as nature and a "sign of nature" not only beautifies what was once a barren hillside, it also permits each student to contribute to the creation of the UT being "full of trees," like 
Esperanza's home. As I explain in the next section, this strategy is a central component of the UT's vision for higher education and regional development.

Figure 12 - View of the UT and newly planted trees from the top of the library (2016)

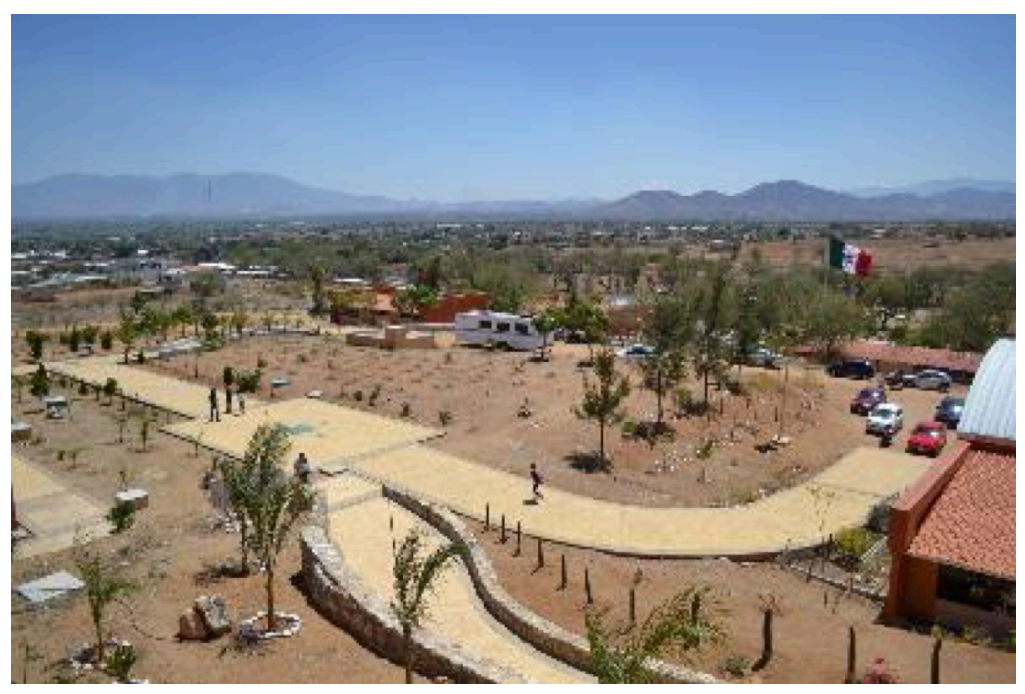

Source: Universidad Tecnológica de los Valles Centrales de Oaxaca

Representations of Space: "Conocimiento Práctico que Transforma",18

Representations of space are combinations of knowledge about how spaces should be, their purpose, and the ideology held within a space. In this section, I illustrate how the UT's administration creates institutional space as a space of change, transformation, and forward progress. These ideas "have practical impact" on the spaces of representation the lived space I describe in the following section - and also have a "substantial role and specific influence" in the production of space as a whole (Lefebvre 1974, 42). These representations are, however, always abstract, creating imagined "conceived"

\footnotetext{
18 "Practical knowledge that transforms"
} 
relationships between objects, space, and people (Lefebvre 1974). Although Lefebvre (1974) argues that representations of space present hegemonic and dominant ideologies that eventually come undone as the spaces of representation outweigh them, this may be only partly true in the case of the UT. Institutional policy and discourses shape the student experience by encouraging "transformation" and change.

At the UT's 2016 graduation ceremony, the university's President, Maestro Julián Luna, explained to students, families, and invited guests that the university's responsibility should be to "assimilate ancestral culture with the development of professionals or a professional with global perspective.” Maestro Julián himself hails from the famous Zapotec mountains, the Sierra Juárez, from where renowned nineteenth century Mexican president Benito Juárez descended to the city to learn Spanish and study. In his speech, Maestro Julián also quoted Jose Vasconcelos, the Oaxaca philosopher and politician: "In these moments I don't come to work for the university, but rather to ask that the university work for the people." He continued:

We need universities to have a greater connection with society. A connection and practical knowledge that transforms. Six and a half years ago, we received a command: give life to the UT, embedded in San Pablo Huixtepec. Like a good inheritor of the ancient Oaxacan tradition who had in his hands something...that had to be molded, together with my partners who are present here... the administrative base, but with great force and above all the contribution of parents and the knowledge and new hope of the students, we have forged an institution.

Maestro Julián's reference to "practical knowledge that transforms" reflects the explicit mission and vision of the university. The phrase adorns vinyl banners hanging at university-sponsored events, appears on letterhead, and is mentioned in nearly every university-sponsored gathering. This literal and symbolic sign does not "exist in 
isolation" (Lefebvre 1974, 132); rather, as Lefebvre (1974, 132) explains, "The links between signs and their articulation are of major importance." Signs like "practical knowledge that transforms" emphasizing a rhetoric of transformation have ultimately become the "focal point of a system of knowledge" within the institution. The UT's professors and students proudly explain that their motto and the educational model based in "seventy percent practice and thirty percent theory" ensures students' education is relevant to labor force needs and contributes to regional development.

In his speech, Maestro Julián also used the specific case of Vicky and Ernesto, two well-known students on campus, to illustrate the transformative power of the UT and its education model. The couple comes from a Zapotec community Maestro Julián described as "six hours down a dirt road tucked away outside of Miahuatlán." He discussed greeting them with the traditional Zapotec greeting, "padiush," and detailed their journey together overcoming economic barriers, ultimately culminating in their presence at the graduation ceremony as young professionals, transformed from their previous selves but with proud roots in their community. "We have the certainty that Ernesto is going to return to his community, and he is going to change not only his reality but also is going to mark the community as one of [its pillars]." Maestro Julián's illustration of these two students creates a representation of space for the institution and rural Oaxaca. He draws on an "ensemble of images, signs and symbols" rooted in and building on collective understanding of rural Oaxaca and students (Lefebvre 1974, 288).

Phrases like "six hours down a dirt road" and "tucked away" demonstrate the representation of space created in order to understand rural UT students. The UT's 
representation of space is "full of juxtapositions, of proximities, of emotional distances and limits" (Lefebvre 1974, 288). Maestro Julián - and many UT faculty and staff - both contrast the university space with rural Oaxaca and its "comunidades" 19 and claim direct or distant family connections to it. UT students and faculty simultaneously live rurality and represent rurality as if from the outside, and rural connections and imaginaries both guide and diverge from institutional goals. In this way, constructions of rurality and the UT are interconnected and depend on each other (Lefebvre 1974). The idea that the UT and higher education are transformational presupposes rural communities and people need transformation. Similarly, rural spatial practices represent authenticity and tradition - like via food preparation, described above - if other professional or non-traditional spaces exist in contrast. The pre-existence of certain "spatial arrangements...and their attendant imagery and mythic narratives" shape how rural and university spaces are represented and lived (Lefebvre 1974, 230).

Additionally, the UT's emphasis on international and out-of-state learning experiences promotes a globalized representation of space. As of December 2016, 201 UT students had some type of international experience in the form of short learning trips and internships since the university began internationalizing several years prior. Corbett, Mata Sánchez, and Elder (2016) show that global opportunities for students are relationship dependent, requiring significant institutional flexibility, which the UT has successfully maintained so far. This international focus significantly affects student

${ }^{19}$ Community: used in Oaxaca to connote a small, rural, tight-knit town; not the urban city 
learning and personal transformation. When asked about unexpected academic experiences, Lupe, the young woman introduced earlier, recounted a trip to Puebla, the first time she had left Oaxaca:

I went to Puebla. Because I hadn't left [Oaxaca], it was something very exciting to leave. Thanks to being in this university, I got that opportunity to see it. And I could see big restaurants....and we went there, and well it was beautiful to see how they set the tables, how they had the restaurant set up...And well it was an unexpected experience because I didn't even think about that. I only thought when I got to the university that it was like study, study, study and be in one place only, but now that I'm here I realize that it's not like that. When one studies, they acquire more experiences leaving, visiting other places, and getting to know other cultures, people, and stuff like that.

From his experience as a professor, Chef David also commented on the benefit to students" "attitude" and "vision" after travel outside of Oaxaca:

One of the first trips with the first cohort was to Guadalajara. And there were a lot of students like that from communities that, being in the streets of Guadalajara...Well, there's a monument there and it's the Ángel de Independencia. And it's this enormous stone pillar. So [a former student] looked at it and said, "Chef, how did they do it to lift it up so high?" And because she had never left her hometown - here in San Pablo was the first time she left in order to study - and we took her all the way to Guadalajara! So that change that you undergo in university isn't just a change and academic development but rather a cultural change. It's a shock. There is something deeper [in you that you can leave and get to know.

Chef David's story illustrating students' moments of realization and "cultural change" alludes to the cultural capital (Bourdieu 2011) students gain as they learn to move in new social groups, become accustomed to new physical spaces and spatial practices, and internalize new representations of spaces. Transformation through travel experiences outside Oaxaca forms part of the UT's representation of space. Discourse like Chef David's emphasizing the "shock" and Lupe's incorporation of travel experiences as an 
integral part of her education contributes to the "ordering, generalizing, abstracting" and acceptance of a globalized educational model (Elden 2004, 44). Institutional representations of space encouraging transformation through de-localized learning create extra-spatial, global student identities, what Appadurai (1996) terms ethnoscapes. This is an example of a juxtaposition made by the UT's representation of space that simultaneously relies on localized identity in rural communities and interconnected, global ethnoscapes. Thus, although often positioned as dichotomous in local imaginary and discourse, again we see the strong relationship between rurality and larger urban and global culture.

Although the UT's de-localized representation of space encourages young people to emerge as global actors (Meseguer Galván 2012), it also responds to capitalism's external demands. This epitomizes Lefebvre's definition of representations of space as hegemonic discourses perpetuated by technocrats. While some students find employment in other parts of Mexico or countries in South America and Europe, the UT often boasts through news releases on its website and social media that it is the "university of businesses and communities" in Oaxaca, emphasizing its response to local needs and providing high quality employees (Universidad Tecnológica de los Valles Centrales de Oaxaca 2013). This draws the global into local rural spaces. For example, many students intern with local organizations or businesses and create projects that address public and private sector needs. Mexican universities' educational models reliant on strong linkages with the private sector represent a national shift from creating democratically engaged citizens to forming "economically competent [and] adaptable workers" $(2005,329)$. 
According to Lefebvre's (1974) critique of representations of space and technocrats and technologies that "mediate the production of space" (Elden 2004, 185), the UT administration's focus outward and toward the local and international private sector is a technology that "transforms," as the motto claims, while favoring private sector values. For example, the two-year programs are designed to be "extensively linked to the business sector [in order to] permit [students'] short-term incorporation into the workforce" (Universidad Tecnológica de los Valles Centrales de Oaxaca 2013). Short programs "optimize time," providing "human resources required by society and business," and the UT's website emphasizes the curriculum's flexibility that adapts to business and regional needs (Universidad Tecnológica de los Valles Centrales de Oaxaca 2013). This social representation of space encourages students to adopt a certain professional habitus (Bourdieu 1977), which I analyze in depth in the following chapter.

The UT's educational model and administrative discourse as a representation of space relies on contrasting spatial practices with rural Oaxaca while promoting students' professional development through personal transformation and incorporation into the labor market. Representations of space presented by the UT administration both include and expand on rural Oaxaca; the university is both rooted in local, "ancestral culture" and incorporates global perspectives into its curriculum and the student experience. As I show in the following section, however, "the social and political (state) forces which engendered this space now seek, but fail, to master it completely" (Lefebvre 1974, 26). The lived experiences of rural women at the UT - their spaces of representation - build on and add nuance to the administration's representations of space. Rural women's 
individualized experiences contribute as an essential component of the production of space in rural Oaxacan higher education.

Spaces of Representation: "We All Came to Learn”

The space of representation "overlays physical space, making symbolic use of its objects" and constructing itself through interactions with the physical world (Lefebvre 1974, 39). Rural and urban students converge on the UT campus, together creating distinct spaces of representation and lived experiences. When the university first began offering classes in 2009, it drew primarily on communities around San Pablo Huixtepec and toward the Sierra Sur to the south for its student population. With the university's expansion and solidification of its reputation as a quality institution, increasing numbers of urban students are also enrolling. In this section, I use interview data to analyze the discourses about rural students and rural women in particular, their response to how they feel they are perceived, and their experiences relating to their classmates.

Meseguer Galván (2012) notes historical tendencies to create a strong relationship between rurality, poverty, and indigeneity. Although indeed rural areas correlate more strongly to poverty, we must remember the economic and social interconnectedness between urban and rural areas (Meseguer Galván 2012). The two spaces rely on each other. A rigid rural-urban dichotomy conceptualization overlooks the symbolic and cultural importance of rural Mexico in national Mexican identity, a notion that is drawn on in urban settings (Bonfil Batalla 1996). Feminist geographers Little and Austin (1996, 103) argue that "romantic vision[s]" of rural spaces with cohesive family and community 
life are fundamentally constructed upon patriarchal concepts of gender relying on women as a central wife and mother figure, anchoring the home within the community and upholding a traditional rural idyll. Although increasing numbers of women are able to express more agency regarding marriage, pregnancy, and public participation, strong gendered divisions of labor persist and dictate much of men and women's daily routines (Curiel Covarrubias 2002). Espinosa Damián (2010) posits that the image of rural women has been created and reified through this division of labor. Many primarily middle class students and professors from urban communities continue the narrative of rural women (Chatterjee 1989), like Emma introduced in the beginning of this chapter, in their homes, upholding traditional values with limited opportunities.

One student from a middle class family in Oaxaca City, for example, explained that unlike for her, "I know some pueblos that at such an age they can ask for a girl. Like she's set aside. 'This girl is going to marry that guy,' even if they don't want to, like, but it's a tradition." Another urban woman, nineteen-year-old Trinidad, echoed this thought in her interview:

Yeah, in some communities if you're fifteen and you're not married, you've been left behind. Like at fifteen-years-old you have to get together with someone... That all influences [them along with] the education that they get. Like they're more closed in communities, but now... now they go to workshops and stuff. But some are closed, really closed.

One of the mentors added that in his class there is a woman "who comes from the region of Miahuatlán where husbands still beat women." These descriptions of rural Oaxaca are implicitly juxtaposed with urban life, reinforcing what Bartolomé (2014) has called the "total oppression stereotype." Usually, life in the city is described by urbanites in either 
neutral terms, as if it were the default option, or in contrast to rural areas. As the dominant norm, urban people explain rural or marginalized areas as the Other (Chatterjee 1989; Saraví 2009).

Rural students perceive and internalize their urban peers' perspectives and comments. Esperanza, the Gastronomy student mentioned above, recounted her experience with urban students when she first arrived at the UT:

When I had just got to the university when we had to do group work it was something that made me feel really bad - horrible - because according to them, they're from the city, no? And well those from the city have more access to technology, but I came from a pueblo and they asked, "What's your pueblo like?" "Well, it's like this, the people are like this." They looked at me all like I didn't know anything! And in the moment of forming groups, they grabbed the people they knew already or people from the city when it was time to work. And at first they just set me aside. And, yeah, seeing all that really affected me, and I felt really bad, and I said, "No, it can't be that they treat me like this for the simple fact that I come from a pueblo!" Because we all came to learn, and they didn't get here knowing a lot of things either. Me neither. We can all learn. Now I feel that, well, excuse me for saying it, but I feel like I'm doing better than they are.

In a separate interview, Lupe reported similar experiences in her first encounter with urban students:

Well the truth is that, well, in my group it was a little bit of work to adapt to them because well... because they had been people more... well they had been more... they've gone more places or had like more... well because they're... from the city. They're a little freer, no? So yeah, I felt a little um (laughs) out of place because I didn't have that confianza or I didn't know how to communicate. I didn't know what to tell them or how to start a conversation.

In the above quotes, Lupe and Esperanza reference "access to technology" and being "freer" in the city. Although this characterization may not hold as universally true, in general Lupe and Esperanza's represent a fair assessment of the perceivable differences between opportunities available in an urban context. That upon arriving at the 
university, rural women's self-understanding (Brubaker and Cooper 2000) continues as a contrast to the identity of women from the city suggests that differences persist through their studies (Manago 2012). Merely entering into the world of higher education does not automatically grant women the characteristics of urban women, nor does it remove elements of rural life. Lupe and Esperanza above illustrate the Borderlands young women inhabit as they negotiate their self-understandings in new representations of space and spatial practices. I explore this more in Chapter Three.

Rural women's classed and gendered (Ortner 2006) spaces of representation influence their interactions with peers on campus and how they use, navigate, and appropriate university space. Similar to Lupe, La China from the Coast region likewise noted that she feels more commonality (Brubaker and Cooper 2000) with her classmates who come from a comparable class and social background:

They work really hard. In their home, they're people... they are humble people but really respectful. They accept you really well and they invite you, "Come here, sit down, eat, don't worry." Other people I get along with because of their charisma. I get along with them more than with other people who think a lot of themselves and all that.

I asked who the students were that think a lot of themselves. She explained that in contrast to her friend group, she can distinguish classmates she is not as friendly with by the clothes they wear: "It's that they always come to school like super done up, and they always have the newest fashion, andan bien fashion. ${ }^{20}$, This distinction between in-group and out-group classmates, between rural and urban, and between "people who think a lot of themselves" and those who "have [their] feet on the ground," according to another

\footnotetext{
20 They're really fashionable.
} 
rural student, has as much to do with social class as geography (Saraví 2009), underscoring the divide between urban and rural Oaxaca. Additionally, rural students just as readily express stereotypes regarding their urban peers. Students feel this divide in their classrooms and form friend groups based on self- and other-perceived identities.

Las Divinas, ${ }^{21}$ a group of young women I encountered in my initial fieldwork at the UT in 2011, exemplified divisions in the use of campus space based on social class and geography. Las Divinas sat together in the back corner of their Business Development classroom with a handmade "Las Divinas" sign hanging on the wall above their desks. Each of the four young women wore stylish clothes and makeup and used cell phones with cameras, a less accessible technology in Oaxaca in 2011. These signs physical and conceived as spatial practices and representations of space - ultimately affected rural women's lived experiences, their space of representation. Excluded from this space (Low 2011) and self-selected group, other women in the class became defined within their cohort in contrast to Las Divinas. Armed with this knowledge (Erdreich and Rapoport 2006), however, women form relationships with women whose "feet [are] on the ground," like La China describes above. Their ability to read space and navigate power structures within them ultimately facilitates their success in higher education (Erdreich and Rapoport 2006).

Although spaces of representation sometimes exclude rural women, they also provide opportunity for dreams, creativity, and imagination about new possibilities (Soja 1996). The presence of rural women in the university's space of representation, their

21 "The divine girls/women" 
appropriation of its spatial practices, and their participation in representations of space create what Meseguer Galván $(2012,45)$ terms "new ruralities.",22 Many rural women imagine themselves in leadership roles after graduation. Esperanza, for example, imagines herself as a Head Chef in a kitchen, providing learning opportunities for other students. She imagines how she will act as a leader based on how her own mother taught her to cook: "First she teaches me and then she says, 'Cut this, I want you to cut it like such, grab the knife like this'...Well I feel that because of her I have the perspective that I am going to be a little demanding." Many students, like La China, dream of having stable, comfortable employment that allows them to help their families:

I imagine myself being in a job that I like, that I'm not forced to be there. I imagine myself in an office job where I can say well, "Look everything I studied was worth it, that all my mom's effort was worth it." Having a good salary I mean that is enough to provide for me, help my family, and help my own self.

Other women use higher education's space of representation to dream of starting their own business through their training in Business Development and Innovation or creating value-added products through coursework in Food Processes. Isidra, a woman from a small Zapotec community in the Sierra Sur, exemplified attainment of this dream and imagination within spaces of representation by creating a business producing and selling her original corn-based drink mix using corn grown by her family ${ }^{23}$. She is now earning a graduate degree at a private university in Oaxaca City. Other women dream of exporting their mothers' traditional tortillas or pottery and always mention being able to help and support their families as a primary motivation. Within spaces of representation, rural

22 This point will be further analyzed in Chapter Four.

${ }^{23}$ See Mendoza Gómez (2015) 
women challenge imposed identity categories by creating new representations of space and spatial practices.

Thus, while spaces of representation are sometimes discriminatory or otherwise has a negative impact on rural women who study at the UT, these spaces also allow for dreams and projections of future selves and the possibilities available to them through education. Women's narratives about their experiences echo the representations of space Maestro Julián emphasizes, as described above, especially with regard to incorporating "ancestral culture" into professionalism and higher education. As I will show in the next chapter, transformation and ambiguity - nepantla - becomes a significant space of representation young women inhabit. Although the physical, ideological, and experiential space of rural homes and communities like Garabato described at the beginning of this chapter may seem a world away while on the UT's sleek campus, in this chapter I have shown how students and administration bring rural life and values with them to the institution. The UT is inherently and intentionally embedded in rural Oaxaca. 


\section{Chapter 3 - The Profesionista's Borderlands: Family Belonging, Conflict, and Transformation}

To survive the Borderlands you must live sin fronteras be a crossroads

- Gloria Anzaldúa, "To live in the Borderlands means you"

“iHijole!” Linda paced up and down the wide hallway, walking in circles, resting her hand on her cheek, fixing her hair, adjusting her dress. Marlene, Linda's friend who came to support her on this big day, calmly smiled and sat patiently in one of the seats outside of the university radio-recording booth. The hallway was bare except for several professors' desks, a refreshment table, and a display case with student projects. Linda was about to present her professional exam, the Mexican equivalent of defending a thesis at the undergraduate level in the United States, and her nerves were starting to get to her.

Linda showed off her new dress that she had custom made for this event. The shiny black fabric reached her knees, and a traditional floral print from the Isthmus of Tehuantepec stretched across her midsection. She was wearing black ballet flats. Marlene and I agreed that she looked great - nothing short of professional. An elaborate French braid gathered in a side ponytail, and her long hair lay on her right shoulder. She adjusted her ponytail again and asked, "And where is my professor!?"

Meanwhile, her parents, older brother, older sister, and niece waited with anticipation in the hall. Linda introduced me to everyone, and I chatted with her sister, 
the first woman to graduate from college from Santiago Tlazoyaltepec ${ }^{24}$, a Mixtec community nestled in the hills on the edge of the Etla Valley. She is now a nurse in Oaxaca City. Their parents stood quietly leaning against the opposite wall, hands clasped or arms resting at their sides, watching other students and faculty pass through the hallway as their daughter made final adjustments to her Powerpoint and fretted over lastminute details. The men in Linda's family were wearing dress pants and closed-toe shoes, a change from the usual huaraches ${ }^{25}$ they wear while tending their fields. Linda's mother wore a nice blouse and a knee-length skirt. Her hair was pulled back with a small braid. Occasionally Linda's brother would lean in to quietly tell their father something in Mixtec. He nodded in agreement and continued to wait.

When the thesis committee arrived, everyone filed into the meeting room, a soundproofed space usually used by the university radio station for recording interviews. Linda quickly slipped off her ballet flats and put on her black, three-inch dress heels. The committee's table was already set up inside with a small bell and the Mexican flag on display. Linda took a deep breath and began her presentation, as I, Marlene, and our other friend, Cristina, watched through the one-way glass window from the recording booth. We wondered what Linda was saying when she seemed to stumble, noted how straight she was standing up and how confident she looked. We giggled as we watched her mother's head nod when she started to drift off to sleep.

\footnotetext{
${ }^{24}$ Like many towns of its size in rural Oaxaca, seventy-four percent of the 4,357 community members work in small-scale and sustenance agriculture (Santiago Tlazoyaltepec 2005).

${ }^{25}$ Traditional leather sandals
} 
For young women like Linda from communities like Santiago Tlazoyaltepec, defending a thesis is the culmination of years of sacrifice and dedication in which they learn to negotiate family and community relationships by living in the Borderlands (Anzaldúa 1987). As I show in this chapter, the ability to redefine one's identity in relation to family and community members in order to navigate changing roles and responsibilities can determine rural women's success in higher education. For firstgeneration and low-income college students like Linda and the women described in Chapter Two, departures from traditional family norms and community expectations internally affect and alter their identities, manifesting externally as tension in relationships (Briseño Maas 2012; London 1989; Moreno 2016; Okeke-Ihejirika 2004; Orbe 2004; Rivera 2010). Anzaldúa (1987) terms this internal struggle nepantla ${ }^{26}$, a key component of her classic Borderlands theory.

Borderlands theory emerged through Anzaldúa's testimonio ${ }^{27}$ as a Chicana living within and between both Mexican and Anglo culture in Southern Texas. These Borderlands are often understood in connection with physical location along a border and always involve a gendered lens that unpacks the dualities used to dictate subaltern women's sexuality, movement, and consciousness (Saldívar Hull 1987). The Borderlands I focus on in this chapter, psychological Borderlands, occur wherever "two or more cultures edge each other" and people connect across class, race, and sexuality (Anzaldúa 1987, 19). Women who inhabit Borderlands form part of a new shifting and dialectic

\footnotetext{
${ }^{26}$ Nepantla comes from the indigenous nahuatl term meaning "torn between ways" (Anzaldúa 1987, 239).

27 See Delgado Bernal, Burciago, and Flores Carmona (2012)
} 
identity that furthers humankind and awakens "dormant areas of consciousness" (Anzaldúa 1987, 19). Although borders are distinct dividing lines - like the division of space and spatial practices between the university and communities - Borderlands are "vague and undetermined" (Anzaldúa 1987, 25). Borderlands space combines multiple versions of self into identities composed of a "series of clusters, a kind of stacking or layering of selves, horizontal and vertical layers, the geography of selves made up of the different communities you inhabit" (Keating 2000, 238). The stacking and layering of selves creates Anzaldúa's nepantla.

Anzaldúa describes nepantla as more than merely a state of being and "the place you live in most of the time - home" (Anzaldúa 2002, 549). She continues:

[Nepantla] is the site of transformation, the place where different perspectives come into conflict and where you question the basic ideas, tenets, and identities inherited from your family, your education, and your different cultures. Nepantla is the zone between changes where you struggle to find equilibrium between the outward expression of change and your inner relationship to it. (Anzaldúa 2002, 549)

Products of multiple cultures, nepantleras (women living in nepantla) transmit values and practices of one to the other(s). At times contrasting values create a choque, and, although transformative, the internal process of growth through choques and nepantla can be painful as one parts from the previous self and grows into a new identity (Keating 2006).

Anzaldúa operationalizes nepantla through conocimiento. Conocimiento describes the space nepantleras occupy in the work of living in the Borderlands; it is both knowledge and awareness. Zaytoun (2006, 153) describes this as a "growth of 
consciousness." It serves as "otro modo de conectar" (another way of connecting) across identities, recognizing the need for finding a "collective, social body" that informs "selfreflectivity...plac[ing] oneself in a state of resonance with the other's feelings and situations" (Anzaldúa and Hernández Ávila 2000, 178). Conocimiento also serves as "an epistemology that tries to encompass all the dimensions of life, both inner - mental, emotional, instinctive, imaginal, spiritual, bodily realms - and other - social, political, lived experiences" (Keating 2000, 177). Seven dialectic stages delineate the conocimiento process. These stages overlap and can occur concurrently or nonchronologically, causing "internal shifts and external stages" (Anzaldúa 2002, 545). One may pass through every stage in one day or "dwell in one for months," never inhabiting only one space but occupying spaces of transition and nepantla within the process of growth through conocimiento (Anzaldúa 2002, 545).

In this chapter I utilize Anzaldúa's $(1987,2002)$ nepantla and seven stages of conocimiento to highlight rural women's feelings, experiences, and actions as they transform into profesionistas (professionals). Using Anzaldúa's (1987) Borderlands theory, I explore changes in identity as they relate to women's understanding of independence, household roles and responsibilities, relationships with family and community members, and performativity and embodiment of professionalism. This chapter's outline follows the seven conocimiento stages. First, in stages one through three, Seismic Shifts and Transformation, women experience transition out of their families' homes and independence. They begin to recognize the new nepantla space they inhabit. Next, in stages four and five, “Remembering Where You're From," I explore 
family connections as rural women's source of motivation and family and community values as foundational aspects of identity. Stage six, Choques and Family Conflict, generates tension between rural women and their family and community members. I specifically explore conflict around three categories: socioeconomic mobility, generational ideologies about women's proper community and family role, and unfamiliarity with the student role and responsibilities. Finally, in stage seven, Becoming a Profesionista in the Borderlands, rural women internalize and embody higher education's spatial practices (Lefebvre 1974) and habitus (Bourdieu 1977). Having become accustomed to nepantla, women simultaneously inhabit multiple identity spaces. These processes and realms of plural identities stretch across spatial practices and representations of space (Lefebvre 1974), a fluctuating environment in which women develop flexible and adaptable Borderlands identities in order to balance home and school demands.

Conocimiento Stages One Through Three: Seismic Shifts and Transformation

Conocimiento's first stages in higher education heighten rural women's senses (Anzaldúa 2002), reveal alternative identity possibilities and trajectories (Manago 2012), and push women into new ideological and physical spaces. Women's introduction to nepantla and nepantlera identities through these three stages provokes emotions ranging from pain due to loss of previous identities to a sense of adventure in anticipation of the unknown. Although some rural women at the UT are able to navigate this adjustment, others, like many first-generation college students, buckle under multifaceted pressures, 
influences, and competing values. First, students experience a break away from typical family expectations; in stage two, they may feel split between two competing realities; and in stage three, they grapple with moving forward into nepantla or returning to their previous selves. Retention of rural women in Oaxacan higher education depends on their successful understanding of and transition through these first three stages of conocimiento.

For women at the UT, the first stage of conocimiento is often experienced when they leave their parents' home and move to San Pablo Huixtepec. Breaking away from women's traditional family and community role situated within the home and kitchen spaces, as explained in Chapter Two, by leaving to study and pursue individual goals can feel like an internal seismic shake (Anzaldúa 2002). Nevertheless, time passes as women live with roommates or alone outside of their parents' home, become accustomed to an independent lifestyle as young adults, and enjoy more personal freedom (Gallardo Vásquez 2007; Rivera 2010). Eventually visiting home loses urgency, and trips back become fewer and farther between (London 1989). This change in intensity of longing represents a progression through the initial stages of nepantla: a sense of being split into two (stage two), followed by "despair" and "hopelessness" at the thought of separation from the previous self (stage three), and then a "call to action" that pushes women forward in order to "undergo a conversion" (stage four) (Anzaldúa 2002, 545). ${ }^{28}$ Urban students who remain living at home or whose family already occupies a professional space may not experience a conversion to the same extent as rural women. La China,

${ }^{28}$ This pattern also parallels Campbell's (2004) Hero's Journey. 
from the coastal region of the state, discussed her experiences with nepantla's first stages in terms of her relationship with her mother:

I used to wait really anxiously for breaks so that I could go home. We had barely left school for break, and I was already at my house. And when I had to leave, "No! I don't want to!" So I was here missing my family a lot. I communicated a lot with my mom.

Betasa, another student raised in what she describes as a "traditional home" with "values like they had in the pueblo" described her experience leaving her parents' home for the first time to study in Spain. She experienced her "conversion" through nepantla as a painful process:

My dad is also a dreamer like me, and he supports me completely, and he is the biggest motivation that I have...My mom, too, but when I left, yeah, it was painful. Leaving my family, going, and coming back... I found a new, very different person there. And I came back as a different person.

She paused for a moment to collect her thoughts and dry her tears, "And yeah, it was painful, but now it's really satisfying." Betasa's example of responding the "call to adventure" (Campbell 2004), or the first stage of conocimiento, shows her initial acceptance of conocimiento. Her experience "[finding] a new, very different person" while away is like Anzaldúa's (2002) second stage of conocimiento, where feelings of being split in two begin to emerge. Identity links to these experiences; students become "split between before and after" when transformation occurs through academic experiences like Betasa's studies in Spain or La China's studies at the UT (Anzaldúa 2002, 544). Presented with alternatives, nepantleras begin viewing multiple options for identities. In conocimiento's third stage, La China, who "wait[ed] anxiously for breaks" and visits home, grappled with the "refusal of the call" to adventure (Campbell 2004), 
stalling to avoid the pain of nepantla Betasa describes. Nepantleras despair at the thought of leaving behind their previous identities and may dwell in the pain of feeling homesick or "very different." Students begin to realize the impossibility of returning to one's previous self after transformation.

La China and Betasa's reflections on their passage through these first stages of nepantla compare to the experience of first-generation college students in the United States. Like many first-generation and other college students, women at the UT experience feelings of guilt, loss, and irreversible change that separates them from family and community (Gloria, Castellanos, and Jones 2003; Moreno 2016; Nevarez 2001; Orbe 2004; Rivera 2010). Now out of the initial stages of shifting and discomfort, Betasa is proud of the person she became, especially her outgoing nature and ability to adapt and move in new social and professional environments. Her tears underscore conocimiento's emotional weight, however, and her description of realizing her change process as “painful” represents Anzaldúa’s symbolic analogy of internal seismic shaking. Like firstgeneration Latino students in the United States, for example, she may have felt increased guilt at leaving culture and family behind (Rivera 2010) or pressure choosing between family and academia (Gloria, Castellanos, and Jones 2003; Nevarez 2001).

These social and cultural pressures sometimes result in students discontinuing their studies. Rosita is an example of a student who stalled in conocimiento's first stages and never made it into the Borderlands to form a new or dual identity. In 2013 during my fieldwork as a Fulbright researcher, I met Rosita in her first term of school. She was nineteen at the time and the daughter of farmers from a small town in the Sierra Sur. 
Everyone in Rosita's cohort looked to her as an outstanding student; she was shy, studious, and had a warm smile and bashful eyes. On a goal setting assignment, Rosita, like many students, wrote of graduating from college and starting her own business. One day she stopped showing up to class. I asked around, checked with her friends, and spoke with her mentor. For a while, everyone was as puzzled by Rosita's sudden disappearance. Eventually news spread that she had gotten married suddenly and returned to her pueblo to live with her new husband. I reached out to Rosita multiple times but never received a response.

Because I was unable to follow up with Rosita to ask her about this personally, many reasons could explain her sudden disappearance from the UT campus: family problems, dissatisfaction with her major, or even simply love. When I asked her classmates and mentor, however, people who knew her explained that "le ganó su cultura" (her culture won her over/beat her) ${ }^{29}$. Pressure to meet family and community expectations (London 1989) combined with the "internal seismic shake" of Anzaldúa's conocimiento may have led her to choose a more familiar path. The disruption in intergenerational continuity (London 1989), especially in indigenous and farming communities (Stephen 2005) as was Rosita's case, reverberates through rural and firstgeneration students" experiences at the UT. The "power of [their] family voices" via messages from family members about responsibilities in the household, expectations for behavior, and hopes for the future and professional achievement echo in students' minds, even when fully immersed in the UT environment (London 1989, 166).

${ }^{29}$ See Chapter Two for an expanded analysis of dichotomous representations of space. 
Additionally, Rosita and students like Lupe and Esperanza, introduced in Chapter Two, contrast their class and cultural background with that of their peers. Although ninety percent of UT students are first-generation college students (Universidad Tecnológica de los Valles Centrales de Oaxaca 2013), a smaller number of students' families are subsistence farmers. Rosita and her best friend in their cohort, Kristi, bonded over their families' farming background. When I asked Kristi about her friends in the cohort, she explained, "Rosita, like me, has a family of farmers." Thus, as Rosita observed the rest of her classmates, she may have felt shame upon comparing the divide in social class (Banks-Santilli 2014; Ramírez García 2012) and ways of speaking or interacting (Rivera 2010). This illustrates Anzaldúa's choque, as Rosita, "like others having or living in more than one culture...get multiple, often opposing messages. The coming together of two self-consistent but habitually incompatible frames of reference causes un choque, a cultural collision" (Anzaldúa 1987, 100).

Although limited data impedes my full understanding of the Borderlands' impact on student retention and specifically Rosita's situation, some of these effects can be seen in the recent university census. As shown in Figure 25 (see Appendix A), in majors like Business Development, fewer than half of women continued to pursue a four-year degree after completing the two-year program. This pattern parallels first-generation college students in the United States who complete degrees at much lower rates than their peers (Jehangir 2010). The combination of shame, pressure to conform to intergenerational expectations, the prospect of marriage awaiting her in her pueblo, and the financial burden on her family may have simply been more than Rosita and students like her can 
bear.

Entering the Borderlands and gaining conocimiento requires rural women to straddle dual cultural realms and expectations. While often women overcome initial obstacles, "pain," or discomfort and continue through other overlapping layers of conocimiento, rural women like Rosita may find the confluence of multiple barriers and family or cultural considerations overwhelming. The UT and universities like it throughout rural Oaxaca and Mexico serve primarily first-generation college students (Ramírez García 2012). Despite this, limited systems or procedures exist to detect and retain women at risk of dropping out - of having their "culture win them over." In order to be successful and "survive the Borderlands," women at the UT must follow Anzaldúa's $(1987,217)$ advice to "live sin fronteras" (without borders) and "be a crossroads" of culture and identity. In the following section, I detail stages four and five of conocimiento, where rural women begin to feel at home in the Borderlands by reconciling their emerging dual identities.

\section{Conocimiento Stages Four and Five: "Remembering Where You're From"}

In stages four and five of conocimiento, nepantleras begin to feel at home in their transformed identities. After the tumultuous first stages described above, rural women draw motivation and inspiration "para seguir adelante" (to continue forward) from their family members, especially their mothers. In stage four, women find motivation to push ahead. During the fifth stage, women contrast their previous realities, lives, and selves with the new spaces (Lefebvre 1974) of the UT and begin to internalize additional 
identities. Nevertheless, rural women recognize the importance of their community and family values and defend and retain them as central elements of their emerging professional identities. Nepantleras in these stages thrive in the liminal, ambiguous identity spaces they inhabit, stacking new ideas on top of old ideas and sorting through aspects of their selves that no longer belong (Anzaldúa 1987).

The "call to action" in conocimiento's stage four propels women into new dimensions of identity construction (Anzaldúa 2002). Many urban and rural women report that their families, specifically their mothers, are their primary source of motivation and inspiration. Given that the majority of rural women in previous generations were unable to study beyond middle school, UT students' success in higher education simultaneously fulfills student and family dreams of social mobility through education. In her speech at the 2016 UT graduation ceremony, Lucy, a campus student leader, introduced in Chapter Two, highlighted the importance of parental support of education. In addition to overcoming financial and cultural obstacles to university studies, Lucy was diagnosed with cancer as a young girl. She explained the importance of her mother's support to students, parents, and UT faculty and administration:

I especially want to thank my mother who never lost the hope that I would win the battle against cancer. She was in every moment with me. Today I want to tell you, Mom... (Lucy pauses to cry, the audience claps) Today I want to tell you that after overcoming cancer, thank you for motivating me to continue living, and, above all, thank you for those cups of coffee when the days weren't long enough to finish all my school activities. Thank you for staying up late with me...Today we're here to celebrate an achievement, an achievement that isn't just ours, but also yours (referring to students' parents in the crowd). Graduating is teamwork...Thank you for being, in the vast majority of the cases, our source of motivation, inspiration to continue forward. 
Ramírez García (2012) explains that although academic support from families of firstgeneration students is nearly impossible, their emotional support is a key factor in student success, even pushing them to out-perform their peers whose parents have college degrees. Praise and encouragement from parents - and for young women, especially their mothers - serves as a consistent call to action and influences aspirations (Huerta Wong and Berumen Jurado 2014), as Lucy demonstrates in her speech. She acknowledges her mother's small acts of kindness and deep emotional inspiration, from "cups of coffee when the days weren't long enough" and "staying up late" to "motivating [her] to continue living" and sharing her achievement with her mother. Like in Easley, Bianco, and Leech's (2012) research, the women I interviewed are acutely aware of the sacrifices their parents are making in order to pay for their education, and everyone I interviewed reported that their parents are supportive of their goals. One woman shared, for example, that she has "to work hard [in school] to feel proud of what [her parents] are doing" by supporting her education. Howell $(1999,108)$ explains that given the economic and social barriers to pursuing education in Oaxaca, "familial support of a girl's or woman's decision to study at post-primary levels is essential." For example, Cintia, a Sustainable and Protected Agriculture student from a semi-rural agricultural community near San Pablo, laughed when she shared her father's loving yet illustrative perspective of sacrifice for her education: "Sometimes my dad says, 'I have a brand new truck invested in you, so take advantage!"”

Conocimiento's fifth stage requires nepantleras to reevaluate their value system. Now that contrasting versions of reality emerge in villages and higher education, images 
that sometimes attack "commonly held beliefs of the [other] culture," students develop an increased tolerance for ambivalence, relativity, and ability to adapt to context and situation (Anzaldúa 2002, 100). Nevertheless, nepantleras must "sift, sort, and symbolize [their] experiences and try to arrange them into a pattern and story that speak to [their] reality" (Anzaldúa 2002, 545). Rural women who study at the UT clearly articulate their community-based value system and seek to build on their values as professionals.

A group of four third-year Information and Communication Systems Technology students demonstrated the sorting and sifting of values in our discussion of independence from family and identity changes. While all rural and urban students I interviewed on campus agreed that independence from one's household and community is a natural part of becoming an adult and maturing (Ramírez García 2012), the four women in this group interview grappled with maintaining authenticity (Saraví 2009). Unlike some of their peers who more readily expressed acceptance of distance and transformation, this group of rural women immediately questioned who would express a desire for transformation and distance from family and community. "Those students must be from the city," they agreed. La Panquesita, a twenty-one year old from San Pablo Huixtepec, continued:

I think that this really depends on where we're from. I think that us four come from pueblos and we were raised like this. I was going to tell my mom something like that ["I feel more independent"], and I told her, "But in the city you see that a lot," and this was her response: "Yes," she says, "but we aren't in the city!" So I think women who say that or do that - hey, I'm not criticizing the city in anyway. I like the city - but those of us that were raised in a pueblo, in my personal opinion, we're raised like this. Including independent if we're in a pueblo or in the city, we shouldn't forget our family.

The women's resistance to transformation would appear to suggest their rejection of 
Anzaldúa's Borderlands and nepantla theory; instead of transforming, they know they were "raised like this" with ideas of assumed and explicit continuity. I argue, however, that immersion in the fourth and fifth stages of nepantla encourages women to adopt an identity that fully incorporates both of their worlds. They embody the Borderlands.

La Panquesita's comments like "we were raised like this" demonstrate the expectations and spatial practices (Lefebvre 1974) concerning familial responsibility and hierarchy placed on young women in rural Oaxaca as distinct from their urban counterparts (Stephen 2005). Her classmate, Julieta, a twenty-two-year-old from the Sierra Sur region, added: “It doesn't matter how high you think you can fly, anyway you're going to continue being the same, so even if you're growing, and it's better to be one's own self and never forgetting where you come from. Your way of being is what's most important." La Panquesita and Julieta emphasize localized and class-based values from their communities, coinciding with what Lucas (2011) terms the Working Class Promise. Similar to Little and Austin's (1996) analysis of rurality constructed dichotomously to urbanity, the Working Class Promise constructs working class membership and identity in opposition to upper classes with a value system based in particular work ethics and commitment to family (Lucas 2011). Like rural women in other contexts who migrate to urban areas for employment opportunities (Gallardo Vásquez 2007; Gamburd 2000; Okeke-Ihejirika 2004), rural Oaxacan women must uphold rural values and standards as "Good girls" (Lynch 2007, 11). This foremost includes respecting multigenerational interconnectivity and interdependence (Stephen 2005) despite "how high you think you can fly" via academic or socioeconomic mobility. 
In the fifth stage of conocimiento, La Panquesita, Julieta, and rural women like them take stock of the "inner landscape" and rural value systems (Anzaldúa 2002, 545).

Rural women build on family and community identity foundations, creating a “new narrative articulating [one’s] personal reality” (Anzaldúa 2002, 545). This reality combines pre-nepantla identities with aspirations, recognizing the simultaneous achievement of goals, (dis)connection to or from family, and the sacrifice higher education pursuits necessitate. For example, one woman in our group interview articulated this identity change as "little details": "I think that little details about me have changed that have helped me improve. And I think that, yeah, that essence that is still there, that person, is there. But now it is developing." This student retains significant elements of her core identity and has "improved" or "developed" during her studies at the UT. In contrast, however, Julieta and La Panquesita's peer, Betita, described undergoing complete change after moving to San Pablo.

I feel like I have changed practically my whole way of living, of seeing things, and even more because of the place I'm from. It's far, far from the city. My way of life was totally different. And I've changed practically everything here...And to be something in life one needs to, well, try really hard and sacrifice some things. For example, distancing myself from my family.

The daughter of a homemaker and migrant worker from a town a five-hour drive into the Sierra Sur, Betita struggles to find aspects of her family and community identity relevant to higher education and life in San Pablo. Nevertheless, she suggested to "never forget where you're from" in order to "always have your feet on the ground." Betita's present inability to reconcile community identity with "be[ing] something in life" demonstrates the incompatibility of Lucas' (2011) Working Class Promise with upward mobility. 
Nepantleras become skilled at balancing these competing value sets, at times struggling, like Betita, or holding firm to community and family, like La Panquesita and Julieta. The Borderlands composed of multiple realities and relational identities provide "liminal, inbetween space" for women to choose between stacked or layered selves (Keating 2000, 168). New identity narratives and struggles with ambiguity and choice emerge as rural women situate themselves within two social contexts: as emerging professionals embedded in rural Oaxaca and as rural women living and working in professional environments. Like Anzaldúa (1987, 43), wherever these women go, they “carry 'home’ on [their] back[s]."

\section{Stage Six: Choques and Family Conflict}

Family and community members resist rural women's nepantla process of setting out on their own, splitting into two, and moving forward (Anzaldúa 1987). Dialectic nepantla discourse and rural women's acceptance of new roles, new realities, and new identities are subject to constant redefinition and renegotiation. Like Lynch's (2007) analysis of village women who work in urban Sri Lankan factories, as students, rural women become the site on which morality and community values are debated. Anzaldúa $(1987,216)$ writes:

In the Borderlands you are the battleground where enemies are kin to each other; you are at home, a stranger, the border disputes have been settled the volley of shots have shattered the truce you are wounded, lost in action 
dead, fighting back;

In this section, I show how rural women experience choques and confrontations with family and community members due to competing values and change in roles. Rural women in higher education become "the battleground" on which debates about women's changing roles play out. In this context, "enemies" - the opposing values of upward mobility and belonging to the working class (Lucas 2011) - are indeed "kin to each other": grandmothers and siblings, neighbors and childhood friends (Rea Ángeles 2011). With one foot on each side of the border between higher education and rurality, rural women at the UT must renegotiate their relationships and defend their place as upwardly mobile students.

In the sixth stage of conocimiento, rural women enact new understandings of their realities. Although higher education is widely recognized as a path to economic security and increased professional opportunities (Silva Laya and Rodríguez 2012), Moshi (1998, 14) describes it as a "double-edged sword" that while alleviating generational poverty and encouraging development, can additionally "make the same women victims of continuous criticism for abandoning cultural and traditional values.” Indeed rural women at the UT reported expressions of contempt and suspicion toward them as the "edifice" they construct with their new Borderlands, nepantla identities "collapses like a house of cards" (Anzaldúa 2002, 545). In order to maintain cultural continuity and family and community connections, rural women must renegotiate relationships and meet competing demands and expectations on their time and values. I have identified three main points of tension rural women at the UT experience between family and community members 
while in conocimiento's sixth stage: socioeconomic mobility, generational ideologies about women's proper community and family role, and unfamiliarity with the student role and responsibilities.

\section{Socioeconomic Mobility}

First, the challenges to identity and community belonging young women face as a result of seeking upward mobility and increased professional opportunities illustrate the strong connection between social class, place, and identity. Professor Sánchez at the UT described the phenomenon as "crabs in a bucket;" when one person tries to leave or get ahead, others around them reach to pull them back down. "That's how us Mexicans are, ${ }^{, 30}$ he explained. Hilda, a Sustainable and Protected Agriculture major who began our hour-long interview with tears, illustrates Professor Sánchez's “crabs in a bucket.” Hilda is from a small town in the Isthmus region of the state and works hard to support her and her older brother's education. She expressed frustration and exhaustion with the sacrifices she has made. When I asked if she had felt push back ("rechazo") from family or community members despite her best intentions, Hilda explained her version of "crabs in a bucket":

Not directly, but, yeah, there are people that were used to seeing you in the situation that the majority of the people in your pueblo are in. And then you come with a little bit more knowledge, more experience, and you say things that really are true, and, yeah, they're surprised. And they say, "Órale, you were here before just like us, and now you think you're so big and this and that." Like, you feel a little uncomfortable.

\footnotetext{
30 "Así somos los mexicanos."
} 
Hilda's experiences parallel Anzaldúa's $(1987,40)$ assertion that "If you don't behave like everyone else, la gente [the people] will say that you think you're better than others, que te crees grande [that you think you're big/important]." Similarly to Hilda, other students have reported that community elders reject the introduction of new knowledge into household life. For example, a woman from the Sierra Sur described encouraging her grandmother to utilize food preservation and sanitation techniques, like hand washing, only to be met with: “QQuién te crees?” ("Who do you think you are?”). This "volley of shots" (Anzaldúa 1987, 216) further separates rural women from the individuals of their upbringing. Attempts to incorporate new elements of their identity into the old are rejected and unsuccessful (Orbe 2004).

This criticism, however, contradicts the motivations of many students who view higher education as a privilege and opportunity to improve the lives of their family and community members (Silva Laya and Rodríguez 2012). Many students, especially those who study Business Development and Innovation or Food Processes, describe goals of creating business and economic opportunities in their home communities, such as women's cooperatives or exporting locally made products and artwork. Goals such as these, however, may be complicated by community members' perceptions that distance and time away from the community has changed the student too much (Briseño Maas, 2012; Silva Laya and Rodriguez, 2012). As La Panquesita cautioned in our group interview:

Sometimes because people are in college, dan aires de grandes [they put on airs] . .. A lot of girls who study here think that because they're in college, they're in a different level, and now they're going to do whatever they want and stuff like 
that, but no, they can't do that. That's not right.

Especially in indigenous communities, elders worry about cultural continuity and upholding values of collective work and reciprocity which are threatened as young people emigrate from rural areas for education and employment opportunities (Aquino Zacarías 2013). Rural women struggle in nepantla to fit back in their previous molds and demonstrate that they have not changed - even if they have - in order to continue as an accepted community member (Orbe 2004; Rea Ángeles 2011). To avoid the perception that as college students "they're going to do whatever they want" or that they "dan aires de grandes," rural women may downplay their successes in school or avoid mentioning their UT-based activities to smooth over tensions (Orbe 2004).

\section{Women's Family and Community Role}

Second, differing ideologies about women's proper community and family role strain rural women's relationships with their home communities and families, requiring students to balance competing roles and responsibilities. Although young men face significant pressure to provide financially for their nuclear families, families are more likely to see an investment in their education as an opportunity for future economic security (Silva Laya and Rodríguez 2012). Rural women, however, who forego motherhood and marriage not only fail to fulfill women's most important perceived role (Anzaldúa 1987; Howell 1999; Naji 2012; Rea Ángeles 2011), they utilize limited resources in pursuit of uncertain promises and opportunities.

Ana, a determined young woman who left her family's home at the age of 
fourteen to attend high school, exemplifies the challenges rural women face from family and community members. During our interview, she recounted that another family came to ask her to marry their son when she graduated from middle school. She narrowly evaded marriage at that young age, instead opting to go to high school in a larger community several hours away. Ana was motivated to study in order to "not depend on a husband" and to improve her quality of life. As in Lucy's example above, Ana receives motivation from her mother who only attended elementary school due to economic and cultural limitations. According to Ana, her father likewise supports her education because he has a "more open mind" after spending time working in Puebla.

[My mom] wanted to study, but my grandma wouldn't let her. So I had a lot of support from [my mom]... but, for example, my aunts and uncles said, "No, you shouldn't study" or "Why are you putting her in school if in the end she's going to a have a family and it's going to be a waste of money?" And that's like what I was up against. Well I feel like it was more my mom and dad that were up against that aspect because in my family there's the perception that as a woman, you have to stay there....And so when I finished [middle school] I said, "I finished! You see now that it can be done?" The same when I finished high school. And they didn't want me to go to college because it was going to be a waste of money...

Ana's explanation of how she came to study at the UT highlights several important dimensions of rural women's experiences. First, her framing of education as a "waste of money" is consistent with research globally on women's education under constrained economic conditions (“Girls' and Women's Education in Nepal" 2000; Jayachandran 2015; Howell 1999; Organisation for Economic Co-operation and Development. Development Centre 2010; Raymo et al. 2015; Taş, Reimão, and Orlando 2014). Next, that her parents "were up against" community questioning and challenges underscores the importance of holding community respect for authority and influence, especially among 
older generations of community members (Rea Ángeles 2011; Stephen 2005). Allocated according to actions of individuals within each family, "extremely disruptive behavior on the part of one [household member] can cause the entire household to lose respect" (Stephen 2005, 48). Ana's education, for example, caused a disruption in expected behavior patterns. In the short-term, Ana consumed limited resources. In the long-term, her prospects for community involvement (Aquino Moreschi and Contreras Pastrana 2016; Aquino Zacarías 2013; Contreras Pastrana 2014; Okeke-Ihejirika 2004), marriage (Bumpass et al. 2009; Kajanus 2016; Naji 2012), and status as a decent woman (Briseño Maas 2012; Curiel Covarrubias 2002; Lynch 2007) could be threatened. Anzaldúa (1987) acknowledges the contradiction of retaining elements of cultural upbringing within one's identity while recognizing the oppressive structures valuing motherhood and household reproduction that are "imposed" on nepantleras (Anzaldúa 1987, 38). In Ana's case, she has experienced direct confrontation while searching for a pathway that challenges this imposition.

In this sixth stage of conocimiento, the spatial practices and representations of space (Lefebvre 1974) of rural Oaxaca are reified by older generations but challenged by younger women (Rea Ángeles 2011). For example, Ana’s grandmother who believes a woman's place is in the home led to the following dialogue between the two generations as Ana postponed marriage and pursued education:

"You're with him (referring to Ana's grandfather) because you like that life," I told her, "not because I like it!" I said, "and tomorrow when I'm independent of you all, I'm leaving. And if you want to go with me, that's fine, but if you want to live that life, there it is." That's what I said to her! And even though I was little! 
So then my grandma always said, "She's a spoiled brat! ${ }^{31}$ She's a girl that does this!" So I was like, “Oh no!" I mean you, as a girl, you're like, "No way! Maybe it's true!"

Another Information Systems and Technology student, nineteen-year-old Chio from a semi-rural community up the road from the UT, echoed Ana's sentiments:

And it happens with older people. For example, my grandpa thinks that us women were born only to be housewives. And he tells my cousins and me, those of us who are students, "Why are you studying if ultimately you're going to be a homemaker?" And we tell him, "But, Grandpa, we like to study, and it's our decision if we want to. And you don't have any reason to get involved." But we tell him with respect.

Older generations that value a group and collective orientation (Stephen 2005; Vogt 1969) conflict with the individual pursuits of rural women (Manago 2011, 2014; Nelson, Badger, and Wu 2004). Okeke-Ihejirika's (2004) observations among professional, educated women in rural Nigeria, an area also characterized by strong family and community ties and low educational attainment for women, show similar trends. OkekeIhejirika $(2004,82: 126)$ shows that with regard to marriage and career balance "your life is not your own" if a woman wishes to maintain connections to their home community and family network. Although Ana, for example, is firm in her convictions to study, she demonstrates conflicting feelings about her grandmother's expectations with comments like "Maybe it's true!" and her obvious distress over causing familial conflict. Chio likewise mediates her confrontations with her grandfather by explaining her goals to him "with respect." Departing from these normative standards, however, causes community or family members to seek limitations on these women's mobility (Stephen 2005;

31 “Es que es una niña mal criada!” 
Vásquez García 2011; Vásquez Vásquez 2013) and question their purity (Howell 1999; Jayachandran 2015; Lynch 2007).

In a context where chisme (gossip) is used as a form of social control (Pérez Coeto Mateos and Flores Hernández 2007), rural women entering into supposedly corrupt urban or unknown environments can be accused of using education or work as a "ruse to meet lovers" (Howell 1999, 108). Additionally, community members may call into question a woman's morality if she spends much of her time outside of the home and private sphere, underscoring the importance of being a "decent woman" (Aguirre Sulem 2013, 204) and a "Good girl” (Lynch 2007, 11). For example, after periods of absences from the community, rural women reported hearing comments like "Por fin te dejas ver" (Finally you show up) or "Pensamos que ya te embarazaste" (We thought you had already gotten yourself pregnant). Lynch (2007) compares this surveillance of women's activity to Foucault's (1977) panopticon. In de Koning's (2009) ethnographic work in Egypt, upscale, mixed-gendered spaces like coffee shops serve as neutral spaces where upper and middle class women mingle in the presence of men; rural women at the UT and in Oaxacan higher education, however, have yet to cleanse the university space of its perceived immorality (Briseño Maas 2012). Although women have laid significant claims to university space, as will be explored in Chapter Four, suspicions about women's intentions and morality have an impact on their educational experience. Many older generations fail to understand the new leadership and professional roles rural women play (Gallardo Vásquez 2007; Meseguer Galván 2012; Rea Ángeles 2011), as Ana confirmed: "I think that a woman has to face many obstacles like this in a community. There is 
always going to be someone that is going to tell you, 'You? A woman?"'

\section{Unfamiliarity with Student Life}

Finally, women experience tensions within their households due to family members' unfamiliarity with university students' roles and responsibilities. As firstgeneration college students and nepantleras, they receive "opposing messages” (Anzaldúa $1987,100)$. As quoted above, Anzaldúa $(1987,100)$ explains that "the coming together of two self-consistent but habitually incompatible frames of reference causes un choque, a cultural collision.” In a group interview with second-year students in Information and Communication Systems Technology, women discussed the problems they confront in their households, whether they remain living with their parents or have moved away. "Family problems affect you," one student explained. "You just keep thinking about those things affecting you." "And more than anything, us as women," her classmate agreed. She continued:

Or in my case, in household tasks. There are times that [professors] give you a lot of homework, and [at home] they say, "You don't do anything. You're just there with that computer!" And I'm like, "If you only knew everything that I do with this computer!" And it always happens like that, "You're just sitting there with that computer - Do something! Sweep!"”

A third student added: “They think that you're not doing anything, right? And there's this effect because your parents sometimes haven't gone to school and from the time you're a little girl they tell you, 'You're going to do this at home,' but sometimes it's tiring, right? It's work!" Like other first-generation college students, parents lack of understanding creates tension as students struggle to balance competing expectations (Jehangir 2010; 
London 1989; Orbe 2004).

Given these tensions, women like Janeth, a bright Business Development student from the periphery of the city, try to compensate by contributing to household reproduction, even when her school-home balancing act becomes difficult. She explained,

Sometimes I want to do something [school related], but I mean also I feel that part of prioritizing, also following through with my role in my family...I'm the oldest sister, so that has meant greater responsibility. At the very least I have to check on things, help my mom and dad in household activities because obviously I'm older, there's more responsibility, so yeah. It's been hard because sometimes my schedule is really tight with all my school activities, so I don't take care of some task at home, and my parents have let me know it. They'd like that I'd help them more. They always tell me that when you want to do something, you find a way, so that part has been complicated.

Janeth's concerns about simultaneously prioritizing school and family responsibilities speak to Anzaldúa's (2002) sixth stages of conocimiento. Janeth's "house of cards" collapses when she is unable to fulfill roles as both a student and a daughter, exemplified by her statement that " my parents have let me know it. They'd like that I help them more." Ramírez García (2012) explains that in order for students to uphold family expectations while satisfying their role as students, families often negotiate and redefine responsibilities. Janeth's parents' insistence that "if you want to do something, you find a way" clearly delineates their expectations: Janeth knows that she must conform (Fuligni and Zhang 2004; Orbe 2004) in order to overcome the compounding impact of having renegotiated family rules and expectations for mobility, purity, and early marriage.

Choques caused by upward socioeconomic mobility, disconnects in understanding women's roles, and an unfamiliarity with student life require rural women to switch 
between their student world and home world, claiming both identities simultaneously and balancing competing expectations (Anzaldúa 1987). They are "living between cultures" and "seeing double...First from the perspective of one culture, then from the perspective of another. Seeing from two or more perspectives simultaneously renders those cultures transparent" (Anzaldúa 2002, 549). This transparency gives women access to both of the worlds they inhabit and the ability to transition back and forth, knowledge necessary for their now permanent residency in the Borderlands.

\section{The Seventh Stage of Conocimiento: Becoming a Profesionista in the Borderlands}

In this section, I explore performativity (Butler 1988) and embodied social capital (Holt 2008) in the seventh stage of conocimiento where nepantleras embody dual identities and occupy hybrid identity spaces (Anzaldúa 1987). Unlike in the previous stages of nepantla, rural women appropriate the seventh stage as a new identity category that builds on previous self-understandings. The following analysis shows how women begin by embodying a profesionista ${ }^{32}$ identity as required by the UT's dress code in formal events, for example, eventually leading to new internalized identities and goals. Women learn to strategically bring aspects of identity to the forefront depending on sociospatial contexts. Rural women at the UT skillfully inhabit two worlds, finding belonging in both.

Butler's (1988) theory of performativity illuminates the physical transformation

${ }^{32}$ Similar to the connotations attached to "merchant" and "weaver" in Stephen's (2005) study of the weaving village Teotilán del Valle, where being a merchant implies a higher socioeconomic level, "profesionista" connotes a middle-class category. 
women undergo as they progress through their studies at the UT. Just as gender is always performed, gendered professionalism is a learned performance women internalize as they mimic and conform to university dress code requirements, urban fashion trends, and other representations of space in higher education. Rural women at the UT acquire social and cultural capital (Bourdieu 1989, 2011) through their experiences adapting to new spaces and social expectations, necessary knowledge for both academic and professional success (Silva Laya and Rodríguez 2012). Holt (2008, 238) terms the result embodied social capital, a type of performativity "bound up" with particular sociospatial contexts and "social networks and relationships."

Identifying as a young professional and embodying professional femininity's performative aspects is sociospatially and context dependent (Holt 2008). Within the UT context, women perform professional femininity as required by their program of study. Lupe, the Business Development and Innovation student introduced in Chapter Two, illustrated her interpretation of performed professional femininity during one of our interviews. "Well what I always imagined is that someday I'm going to be like this." Lupe sat up straight, crossed her legs, and held her hands up like she was typing at a computer. She giggled. "Sitting in my office, creating projects... you know, creating projects that, I don't know, help vulnerable groups, and with a great company and stuff like that. That's what I have always imagined."

"Being in an office?" I asked.

"Being in an office," she nodded.

Lupe's identity as a professional depends on the spatial practices of an office 
environment. Far from her mother's life as a campesina, Lupe now imagines herself working at a computer for "a great company." Similarly, in the opening vignette of this chapter, Linda exemplifies the performance and embodiment of professional femininity. Moreover, beyond performance, Linda and Lupe have internalized their identities as profesionistas (Gallardo Vásquez 2007).

Figure 13 - Lupe reading with children in her community during a CMujer service project

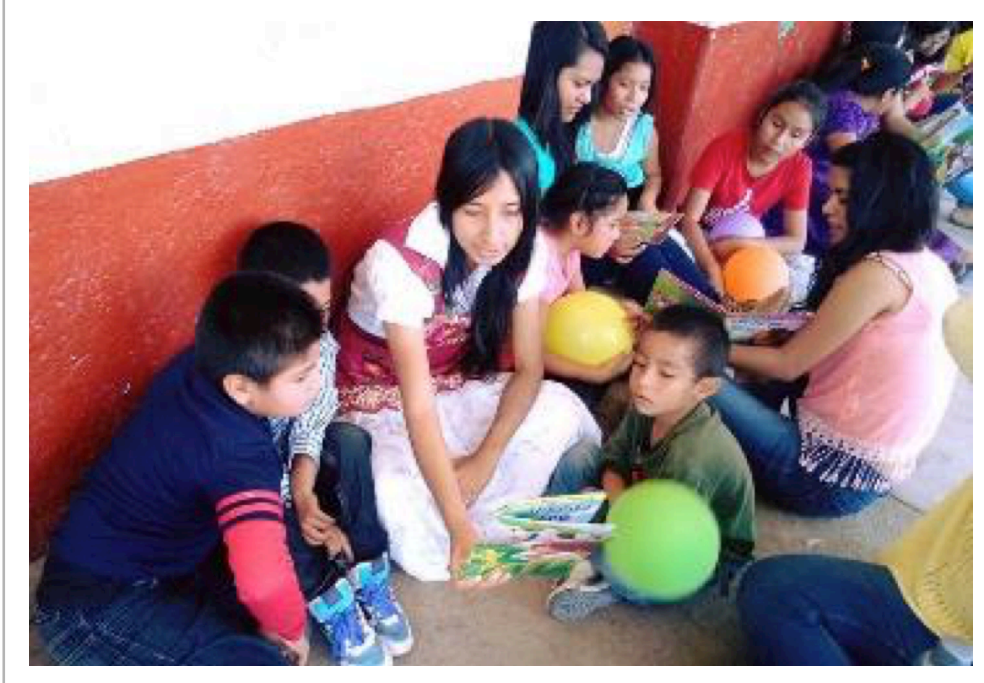

Source: Centro Universitario para el Liderazgo de la Mujer

Foucault's (1977) dressage concept explains this phenomenon. As Rutherford, Conway, and Murphy $(2015,330)$ who studied dressage and performativity among future teachers explain, "Dressage requires the body to move and perform, to know the appropriate costume and acts that satisfy demands of judges (students, parents, tutors, peers and colleagues)...Dressage is far more complex than what to wear for work. It is powerful and nuanced." Furthermore, the body becomes "self-policed" (Rutherford, 
Conway, and Murphy 2015, 332). Linda, introduced in the beginning of the chapter, now naturally tends towards a more professional and urban femininity; there is no need for a reboso ${ }^{33}$, and her dress, though modest, features "modernized" ethnic textiles, a style seen in boutique shops in Oaxaca City. For example, Chef David, the UT's Director of Gastronomy, described one of his students as follows:

She came from the typical Oaxacan community: without makeup, no good hairstyle, and all of a sudden in Gastronomy events, [other students] have taken her, like, they fix her up, put makeup on her, dress her with style and high heels. If you see her, you're like, "Wow." Not because of her clothes and the makeup, but now because of the attitude that she has. No, the first time they fixed her up she was shy. Like, "How do I do this with makeup, with a dress, with heels?" Maybe she couldn't even walk in them! But at our last event, from her attitude to her security, it's something that she's never going to lose, right? . . . And now when you see her you say, "Órale, how cool that she's awakening because that means she's going to grow, and she's going to be able to use everything she learns here at the university." I don't mean in the sense of her beauty but in her attitude. It's really cool. It's really great.

Chef David's description of his student echoes stories of embodiment of transformation found in other education contexts (Dall'Alba 2009; Mavin and Grandy 2016; Momaya 2007; Piñón Lora and Cerón Hernández 2007). The drastic change in this student from a "typical Oaxacan community," although practical for the purposes of socioeconomic mobility, further distance rural women from their families and communities. High-heeled shoes, make up, and urban style reifies rural women's difference in the eyes of family and community members, reinforcing notions of perceived inflated self-importance and abandonment of traditional class and community values. Like first-generation college students in the United States (Banks-Santilli 2014; Orbe 2004; Easley Jr, Bianco, and

${ }^{33}$ Shawl 
Leech 2012), rural women in Oaxaca may find themselves suppressing certain aspects of their professionalism, downplaying their success, or switching between expectations according to sociospatial context.

Gradually this outward embodiment of professionalism also provokes changes in personality, attitude, and lifestyle. Changes are expected of UT students through the "conocimiento práctico que transforma" motto I analyze in Chapter Two, and Anzaldúa (2002, 549) describes attempting to live "according to the old terms" as nearly impossible: “yesterday's mode of consciousness pinches like an outgrown shoe.” Betasa, for example, described in detail her upbringing in the city as a child of two parents from the Sierra. Because her parents raised her with traditional Serrano values, the “awakening" or new "consciousness" she experienced while at the UT was profound:

Now I express myself more. I'm not so embarrassed. I come, I go, I go up and down. I'm really fast. I'm more dynamic. Now my parents tell me, "No one can stop you!" And I'm like, "Too bad! ${ }^{34}$ You had a daughter that was really calm, and now you're going to get to know another facet of her that I'm also getting to know." So it was a pretty radical change. People who know me say, "No, you're nothing like you were before. It's someone completely distinct, completely different," but each day you have to make yourself better.

Hernández Aragón's (2013) research studying similar processes of transformation at the Universidad Autónoma "Benito Juárez" de Oaxaca, the largest public university in Oaxaca, shows how students' identities change through exposure to new people and experiences. From the perspective of students, however, far from opposing rural or indigenous identities, new identities build on and add to community values (Gallardo Vásquez 2007; Hernández Aragón 2013) as “another facet” to get to know or a pathway

34 iNi modo! 
to "make yourself better." Community belonging and identity in relation to community of origin continues as an essential component of identity, as evidenced at the UT by women's insistence to "never forget where you're from" and the various accommodation strategies women employ to maintain family connections despite changes perceived as "radical," rigid, and definitive.

Nepantleras at the UT recognize the high-stakes Borderlands they inhabit and the unique opportunity their access to educational and professional opportunities presents for themselves, their families, and communities. Proud of their heritage and family values, rural women overcome various choques and barriers with the knowledge that both family dreams and cultural continuity depend on their successful embrace of nepantla. Vast cultural diversity among Oaxacan communities requires young people to internalize specific cultural knowledge about community tradition and customs (Aquino Moreschi and Contreras Pastrana 2016; Aquino Zacarías 2013; González Cangas 2003; Schmelkes 2013; Stephen 2005); this simultaneously retains rural women as community members and positions them as ideal leaders with new professional skills and connections. Rural women live and thrive in this in-between space, pulling from tradition and pushing forward towards growth. In the seventh stage of conocimiento, one "shift[s] realities," as Betasa has done, and "develop[s] an ethical, compassionate strategy with which to negotiate conflict and difference within self and between others, and find common ground by forming holistic alliances" (Anzaldúa 2002, 545).

Returning to Linda's thesis defense in the beginning of the chapter exemplifies attainment of balance between rural women's two competing worlds. She has combined 
her knowledge and experiences at the UT into her lifestyle (Ohmer 2010). When Linda finished her presentation and answered the committee's questions, we all waited in suspense as the three professors deliberated the outcome behind the closed door. "There will be three women with degrees in the family now!" Linda's brother beamed. Her sister, the nurse, was the first, Linda would be the second, and Linda's niece who attends the state technological university will be the third. Her niece stood up a little straighter and smiled, looking to Linda as her example. Linda sat quietly with her friends and family, hands folded in her lap and ankles crossed to wait for her results.

Figure 14 - Linda accepting the results of her exam while her parents and family members look on

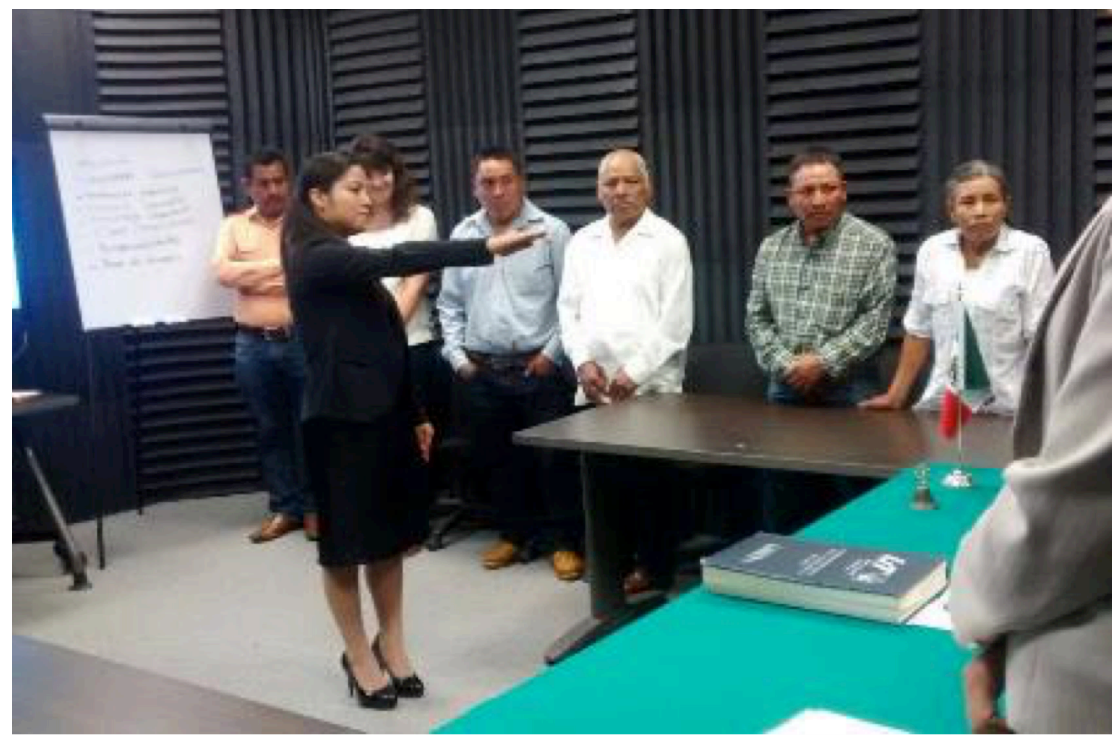

Source: Linda

She passed her exam, the final step in her degree process. We told her to get used to her new title: Ingeniera (Engineer) Linda. "Congratulations, Ingeniera!" “Inge, what do you think we should do about...?" we all joked. Linda blushed humbly. She bounced 
between mingling with her professors and making sure her parents and family were comfortable. Like other nepantleras, in her degree process she has gone against her parents' expectations “by exceeding them” (Anzaldúa 1990, xxv). After the official toast, Linda propped herself up using her mother's shoulder and slipped her heeled shoes off, replacing them with flats and wiggling her toes in relief. 


\title{
Chapter 4 - Building Community in the Thirdspace: CMujer as Convergence and Transformation
}

\begin{abstract}
"I'd like us to be more attentive to women's resistance. Rather than saying, 'Oh poor me, I've been oppressed for five hundred years,' we should get the anger out, lay the facts where they fall but also say 'We are active agents. We never were passive."' - Gloria Anzaldúa, "Quincentennial: From Victimhood to Active Resistance"
\end{abstract}

After classes and work was finished for the day, the UT's Outreach Department team gathered up banners and tablecloths to take to Victoria's award reception. Lucy, Dulce $^{35}$, and I all piled into a mototaxi at the UT up on the hill and were delivered in front of a local psychologist's home and office. The tall turquoise doors opened to an ample, smooth concrete patio where small folding metal chairs were set up in rows and a group of about twelve women all dressed in matching pink shirts were mingling and waiting. "Buenas tardes ${ }^{36}$," we greeted each other as we entered and set up a folding table on a platform at the front of the patio area. Victoria greeted each señora ${ }^{37}$ by name and with a kiss on the cheek.

Victoria was a Gastronomy student in the University Center for Women's Leadership (CMujer), and as her final internship she led this group of women in San Pablo Huixtepec through weekly baking classes. The women were part of a support group

\footnotetext{
${ }^{35}$ These are not pseudonyms. Dulce and Lucy both gave permission for me to use their real names.

${ }^{36}$ Good afternoon

${ }^{37}$ Term for a woman who is usually older (than the speaker) and married
} 
run by the psychologist whose home we were in. ${ }^{38}$ Each had been affected by migration: their husbands had all migrated to the United States or other areas of Mexico, and only some had returned or sent money as promised. Victoria's role was to teach baking classes with the goal of providing another source of income for women who were struggling.

Figure 15 - Las Señoras (front row plus three in back row), Victoria (center, dressed in white chef's uniform), the local psychologist (center, black shirt), and the CMujer team (Dulce, far left; me, back row, second from the right; Lucy, back row, far right) at the graduation ceremony

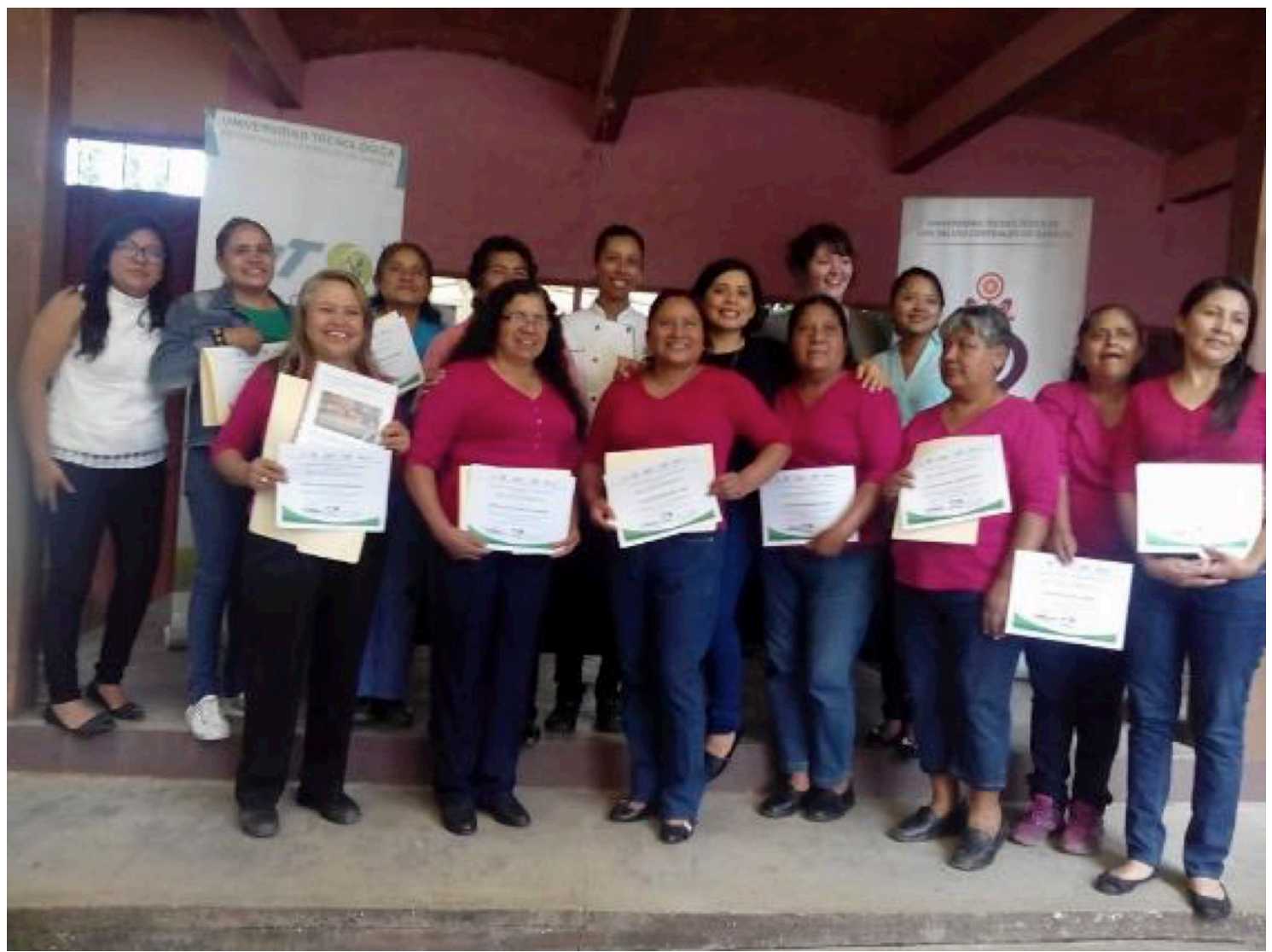

Source: Centro Universitario para el Liderazgo de la Mujer

Economic empowerment was the primary objective, but community building was just as

${ }^{38}$ See Huizar (2015) for examples of other women's groups in San Pablo Huixtepec. 
important.

I observed as each señora individually thanked Victoria for the work she had done planning workshops and coming to their homes each week to bake. They spoke of the experiences they had getting to know each other, visiting each of their friends' homes, attending the workshops with their mother or daughter, and learning new recipes. They made jokes with double entendres I only understood enough to know that I should be laughing, and they hugged each other again and again. We all congratulated Victoria and the women on their work, thanked the psychologist for her support, and then Lucy, Dulce, and I hugged each other. After spending so much of our time promoting women's leadership, searching for learning and professional development opportunities, seeking resources, and connecting people to projects, we were simply happy to see our hard work pay off and form part of this growing community of women.

In this chapter, I show how through individual skill building and personal development, young women and UT students like Victoria facilitate women's collective empowerment in rural Oaxaca. I first present an overview of the University Center for Women's Leadership (CMujer) and my role as an activist anthropologist in facilitating its creation and on-going activities (Hale 2008; Speed 2006). I then discuss CMujer as a new space of representation (Lefebvre 1974), what Soja (1996, 2009) terms the Thirdspace, where women forge new identities and create a community along commonality of experience and goal sharing rather than through traditional kinship networks (Rea Ángeles 2011; Stephen 2005). By providing space for women to nurture their own and other's personal and professional growth, new nepantla identities (Anzaldúa 1987) 
converge in the Thirdspace. Women create a collective nepantla identity that redefines the meaning of being a woman in rural Oaxaca and draws multiple generations into local movements for gender equality.

\section{Creating CMujer: El Dream Team and Organization Forming}

I began research at the UT focusing on women's access to education during my undergraduate education in 2011 as a Ronald E. McNair Scholar. With encouragement from my mentor, Dr. Jack Corbett, I leveraged initial contacts with Nydia Mata Sánchez ${ }^{39}$, the UT's Director of Outreach who also studied with Dr. Corbett during her graduate education. Nydia and I chatted during the long car rides through the Oaxaca Valley travelling back and forth between the city and the university, discussing the

Figure 16 - Centro Universitario para el Liderazgo de la Mujer logo

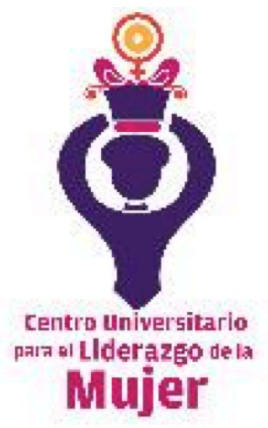

Source: Centro Universitario para el Liderazgo de la Mujer problems we saw on campus and in broader Oaxacan and global society, eventually becoming friends. Why did so many women drop out of school? What does it mean to be a professional woman in male-dominated fields? Who do we draw inspiration from? Dr. Corbett placed strategic opportunities in our path, guiding me towards graduate studies and Nydia and I towards helpful contacts and examples of successful projects and

programs in Oaxaca. Both motivated by our own professional development and a commitment to addressing inequalities, in 2014 Nydia and I launched CMujer one

${ }^{39}$ Not a pseudonym. Nydia gave me permission to use her real name. 
afternoon at a coffee shop in downtown Oaxaca City by creating - what else? - a Facebook page ${ }^{40}$. Eventually this initiative grew into continued research (this thesis) and now informs and acts as a basis for activist anthropology methodologies (Hale 2008; Speed 2006). The process of research both informs and is informed by CMujer's policies and programs, builds on existing strengths, and provides opportunities for reflection.

The initial goal driving CMujer was to promote gender equality throughout Oaxaca by supporting young professional women who will be agents of social change in their communities, connecting with and leading other women. By engaging students, building community, and supporting their professional development, we also hoped to reduce the high drop-out rates among rural women in higher education (Delgado Ballesteros 2012). The need for student support services in an institution serving primarily first-generation college students was obvious as professors recognized and openly discussed students' struggles with adapting to the college environment. Unfortunately, most professors lacked time, resources, or expertise to fully address the particular needs of rural women. Students usually receive attention on an individualized basis from their cohort mentors, sometimes receiving referrals to the UT's psychologist for more in-depth counseling. This means the one psychologist addressed issues for all men and women on campus ranging from trauma, substance abuse, and gender-based violence to mental health, stress management, and healthy lifestyle choices. CMujer aimed to fill the gap in what the combination of mentors and the psychologist had capacity to provide. Because the UT had no institutional policies or programs that

${ }^{40}$ http://www.facebook.com/MUJERUTVCO 
considered gender, CMujer eventually influenced the university's entire approach to serving women.

\section{El Dream Team}

The Outreach Department team and I are the self-described Dream Team responsible for creating, developing, managing, and implementing CMujer. First, Nydia, formerly the Director of Outreach, and I began to think seriously about creating a program for women during my 2013 Fulbright research at the UT. Always forward thinking, full of energy, and a quick, savvy professional, Nydia provided much of the initial impetus for grounding CMujer. In addition to convincing UT faculty and other staff members to support CMujer's work, Nydia conducted the majority of negotiations at the administrative level when, still in its nascent stages, CMujer had yet to result in tangible outcomes for students or the university. Much of CMujer's success is due to having Nydia as an ardent supporter occupying an administrative position at the UT. She recently received a major promotion at the UT: she is now the university President. We anticipate that Nydia's position of authority on campus and within the national Technological University system will facilitate expansion and increase funding to CMujer's programs.

Dulce is the UT's as Outreach Coordinator. From the Sierra Norte, a rural mountain region, Dulce's quick-thinking intelligence, wit, and passion for supporting other rural women motivated her to get involved with CMujer. One of the significant advantages of creating an organization like CMujer is that we each have gained 
professional skills and experienced personal empowerment through our work. Dulce is no exception; she credits CMujer with giving her new knowledge, confianza, and communication and leadership skills. Her tenacious work following-up with individual women who participate, organizing and tracking information, and creating a friendly, welcoming, and inclusive space for women has been central to CMujer's success. While continuing work with CMujer and the UT, Dulce is now enrolled in a Master's degree program in Oaxaca planning her own thesis on indigenous women's experiences in higher education.

Our third Dream Team member is Lucy, who now occupies a central leadership role within CMujer. Lucy, an original member of CMujer's first cohort in 2014, lends invaluable perspective to guiding program development and outreach to the student body, creating an aura of confianza around CMujer and the Outreach Department. As CMujer Coordinator, Lucy represents the organization at meetings throughout the state and country, organizes and facilitates curriculum delivery, and manages communication with the students. The last time I saw Lucy we were marching together in the Independence Day parade through San Pablo. Patriotic brass instruments reverberated off cement walls and rattled in our eardrums as she explained to me her professional plan: She was enrolled in English classes at the time to prepare for a graduate degree. "I want to finish my Master's degree before I'm twenty-four," she confidently explained. 
Figure 17 - Me (back, left), Lucy (back, center), Nydia (front, left), and Dulce (front, center) during breakfast on Independence Day with other members of the Outreach Department

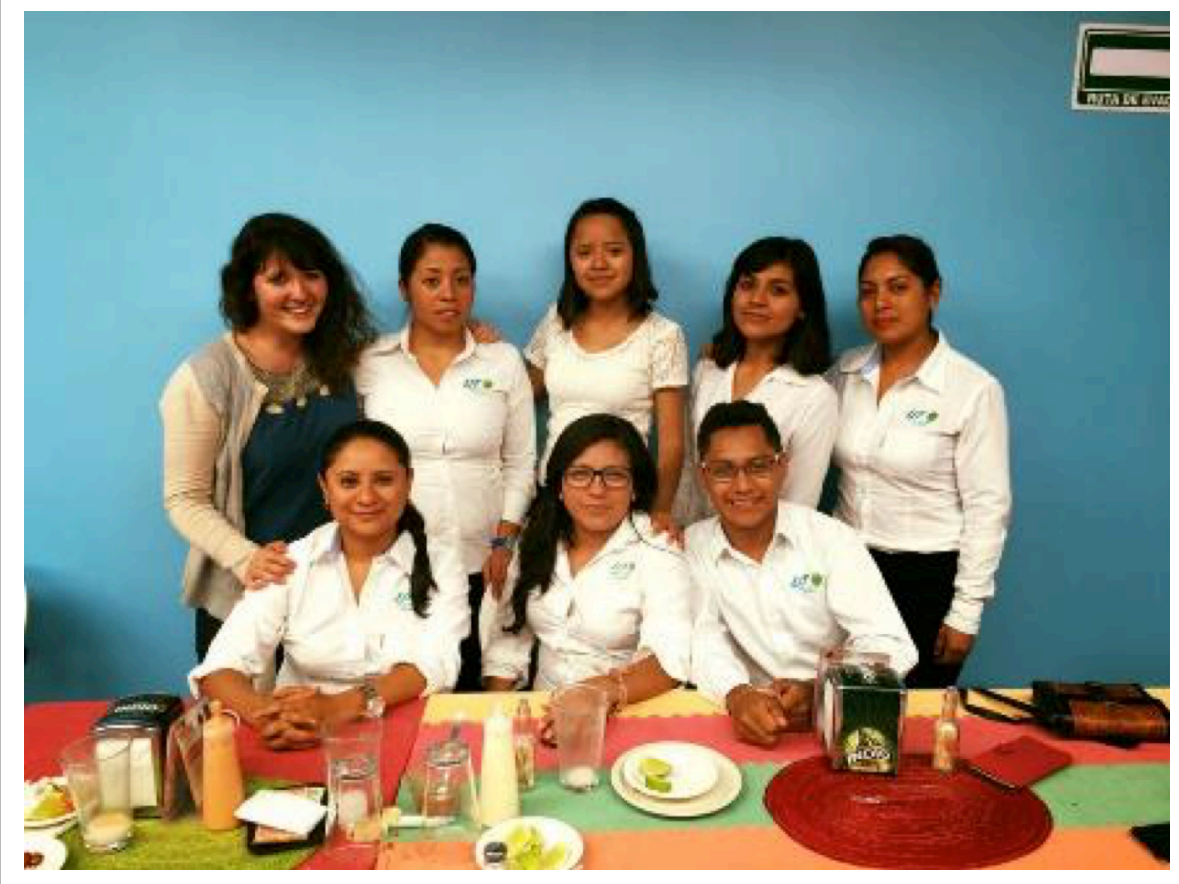

Photo taken on Nydia's phone by restaurant server.

Finally, as an activist anthropologist (Hale 2008; Speed 2006) I have contributed to curriculum development, program funding, recruitment and selection, and strategic planning. From the beginning of my research experience at the UT in 2011 as an undergraduate, students and faculty alike perceived my presence on campus and focus on women's and gender issues as a political act in itself. Associating myself with a political movement in favor of gender equality became both necessary in order to avoid reinscribing power dynamics (Hale 2008), but also in recognition of the strategic connecting role I occupied between the UT and international opportunities and support. 
My engagement with the UT through creating CMujer and conducting research on campus has offered sharing and support with my colleagues and friends, collaboration between CMujer and its nonprofit counterpart based in Oregon (more on this later), and activism in order to change conditions of inequality (Low and Merry 2010). Thus, far from a position of neutrality, I approach my analysis of CMujer as an activist with vested interest in bearing witness to a social movement in support of women's leadership. Mindful of my role working with CMujer in a binational context (Corbett and Cruz Martínez 2013), my position provides a unique perspective on social movement formation and is integral to my activist research methodology (Hale 2008).

\section{$\underline{\text { Program Development }}$}

In September of 2014, eleven students attended our first information session on the UT campus. This first cohort began their work of creating something entirely new within Oaxacan higher education. Initially the curriculum was loosely planned around existing contacts and the limited resources Nydia and I could access. Looking to other programs and organizational models for inspiration, like Portland State University's Center for Women's Leadership or the Fondo Guadalupe Musalem in Oaxaca City (Avellaneda Díaz 2013), we planned weekly workshops and meetings with a variety of public leaders around Oaxaca City. The UT initially provided no funding for CMujer, and the entire program was supported by the Outreach Department's volunteer time on the weekends. With this first cohort we began to create a space (Soja 1996) where young women with common goals could come together to learn about gender equality as human 
rights, develop professional skills like networking, public speaking, and communication, and become confident and engaged members of the UT community.

We also created an international component to CMujer's work in line with the UT's internationalization goal of expanding international learning and employment opportunities for its students. Seeing the need for global perspectives to address local challenges, CMujer facilitates an International Leadership Development Seminar in Portland, Oregon (Corbett, Mata Sánchez, and Elder 2016). In 2015 CMujer provided six scholarships for women to travel to Oregon, where I drew on my contacts in the Portland Metropolitan Area to facilitate a week-long learning experience. The funding for this opportunity initially came from fundraising efforts external to the UT. Since then, two sister nonprofit organizations in Oregon and Oaxaca provide ongoing institutional and financial support for this program, WILL ${ }^{41}$ (Women's International Leadership and Learning) and the Fundación Internacional para el Liderazgo de la Mujer (FILMujer) (International Foundation for Women's Leadership). WILL has additionally created a tuition scholarship program for Oaxacan women at risk of dropping out due to economic limitations. FILMujer provides a basis for expanding CMujer's reach beyond the UT, and the team is currently in the process of seeking new opportunities. A Board of Directors (including myself and Nydia) in both organizations coordinates fundraising events and teams of volunteers to implement the international program.

${ }^{41}$ www.willpdx.org 
CMujer's third cohort is now progressing through an updated, iterative curriculum created with contributions from Lucy, Dulce, Nydia, and myself. Fortunately, the UT has since begun providing funding for Lucy's position as CMujer Coordinator. She facilitates the activities, coordinates speakers, and provides support for the women who participate. The most current curriculum consists of three learning modules: Ser, Saber, and Hacer (Being, Knowing, and Doing). During the first two months of the six-month program, the first module, Ser, focuses on personal development and gender equality including reproductive health, gender stereotypes, gender-based violence prevention, and goal setting. In Saber women focus on professional skills like networking, communication and public speaking, developing resumes, and studying other examples of women leaders. Finally, during the last two months of the program, women focus on project design and development, approaches to marketing oneself and project proposals, and social Figure 18 - El Balero Club de Lectura Móvil in action

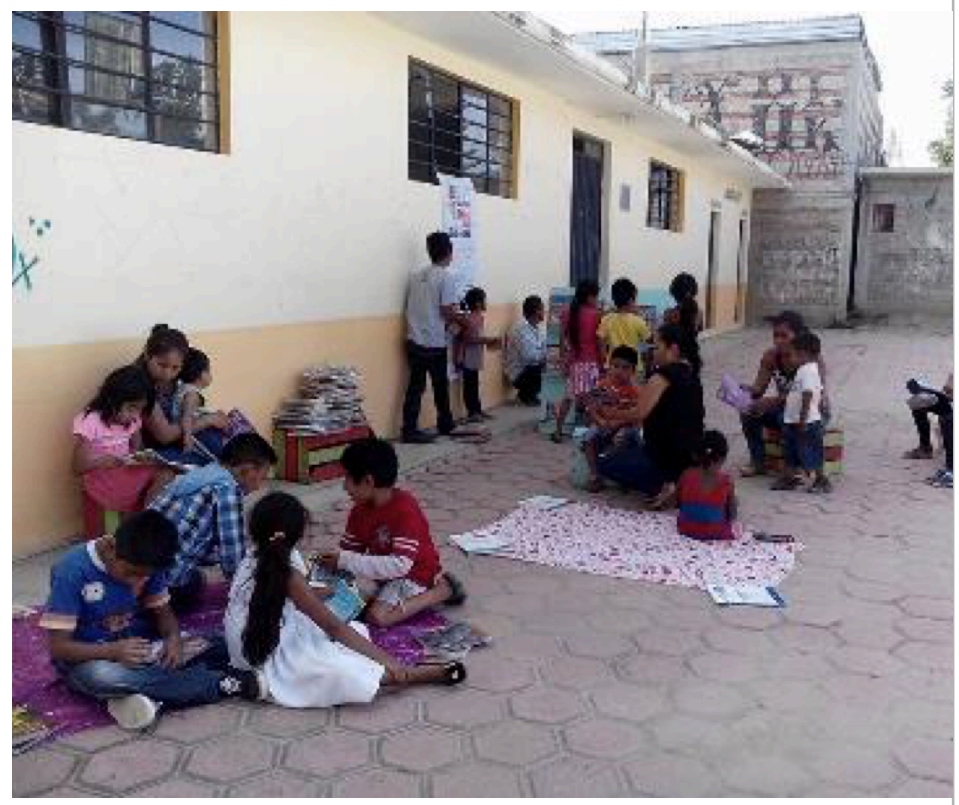

Source: Centro Universitario para el Liderazgo de la Mujer entrepreneurship.

In some instances

within CMujer, interdisciplinary teams of two or three students have organically formed around common interests and complementary skill sets to design their own community- 


\section{Figure 19 - Día Naranja at the UT}

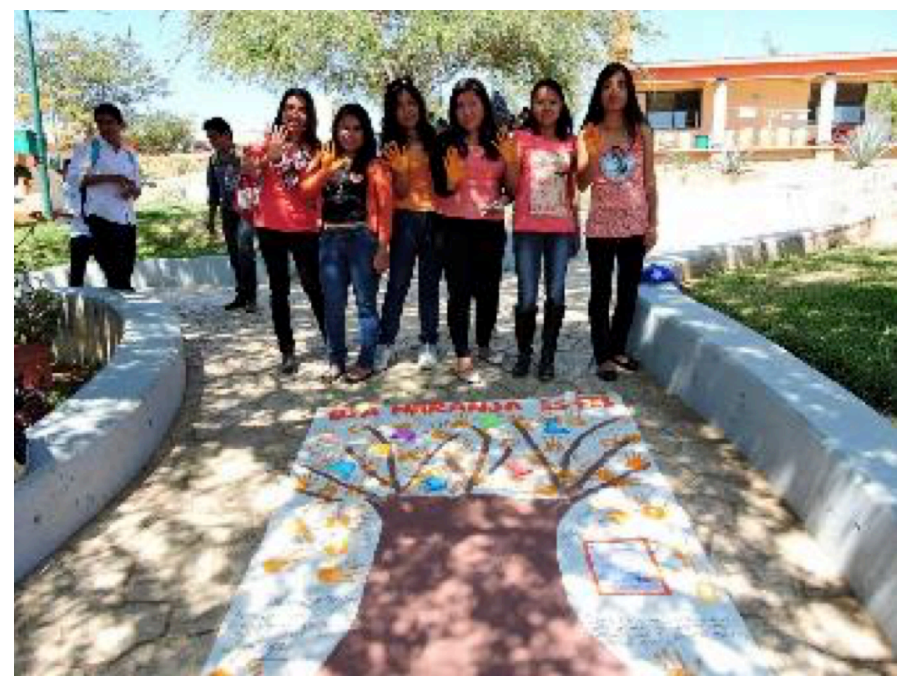

Source: Centro Universitario para el Liderazgo de la Mujer based projects. For example, Lucy and another outstanding student, Karina, co-founded a mobile children's library called El Balero in the urban periphery to promote early literacy and reading habits among low-income children $^{42}$. El Balero has since received national prizes for social entrepreneurship and innovation. Another student from the 2015-2016 cohort, Cintia, created a gardening program called Sembrando Oportunidades. She helps families, especially women, plant and cultivate small plots in their homes, teaching skills and providing extra income or a food source. Other examples include collaborating with traditional artisans to reach broader markets for their art and a solar-powered fruit dehydrator for women to use in rural areas that preserves fruit and creates a value-added product. Each of these projects necessitates community-based collaboration in project design and implementation.

CMujer also hosts other gender equality and professional development activities on campus at the UT. For example, each month the CMujer team commemorates "Día Naranja," or Orange Day, a day designated by the European Union to bring awareness to

42 https://clubdelecturaelbalero.wordpress.com/ 
gender-based violence. CMujer also provides written and oral communication workshops for students who speak Spanish as a second language. The goal of these workshops is to increase students' written Spanish proficiency to bolster confidence and success as students. Recently, CMujer organized a bike ride to commemorate International Women's Day in Oaxaca City. Activities like these both foster a sense of broader connection to the university community, bring more students into CMujer's mission, and support gender equality.

\section{$\underline{\text { Participants }}$}

Cohorts of twenty-five women participate in the six-month course. Unlike in CMujer's beginning when the team struggled to attract enough students, women now compete to participate. Beginning in Fall 2016, interested women applied through an online application where the team selects participants based on professors' recommendations, ethnic and socioeconomic diversity, and demonstrated commitment to professional development. The demographic composition of each cohort is about equivalent to the UT's general female population ${ }^{43}$, with some women from urban areas, several from indigenous communities, and the majority from rural and semi-rural communities in the Oaxaca Valley. As is the case for the university as a whole, the vast majority are first-generation college students. During the second cohort, we learned that due to economic constraints some students were unable to travel to Oaxaca City where we hold weekly meetings. We have since implemented a transportation scholarship

${ }^{43}$ Exact demographic data are not available at this time. 
program based on family income and distance from the city to mitigate women's travel expenses.

\section{University Response to CMujer}

At first, faculty and other administrators appeared to feel ambivalent about CMujer's presence and the sudden introduction of gender into campus activities. As time passed and CMujer gained traction, however, more faculty members began recommending the program to their students. The (now former) university President, Maestro Julián, who initially was unfamiliar with such programs, even became a vocal supporter at campus events and a defender against critics within the national Technological University system. Institutional flexibility and Nydia's administrative role that permitted significant autonomy and authority allowed the CMujer team to persist and collaborate across campus with professors as necessary. Especially given the success of the current third cohort, CMujer has overcome general apathy, adapted to the UT's institutional and cultural context, and will be sustainable for a fourth year beginning in Fall 2017. University support has since facilitated CMujer's success as students see their professors and role models supporting gender equality and women's leadership.

The UT's University Center for Women's Leadership (CMujer) challenges stereotypes about women's leadership and builds on loosely-constructed communities that women form among themselves within their disciplines to formalize a sense of belonging and commonality across campus. The presence of this space intended only for women provides an alternative space in which women build confianza (Dyrness 2008a; 
Stephen 2007), free from the male gaze (Mulvey 1989) or assumptions about their intentions in mixed-gendered spaces, as I analyzed in Chapters Two and Three. In the following section, I discuss how community building around collective, shared identity facilitates skill building and cross-generational women's empowerment.

\section{CMujer as a Thirdspace: Collective Identity and Transformation in the Borderlands}

The University Center for Women's Leadership is a new space of representation that facilitates new kinds of relationship and community building. As has been described in the previous chapters, young people contrast their lives in settings like higher education with those of their family members, whose lives are based in kinship ties and accentuated by "an almost unconditional attachment to a series of traditional rules and obligations" that determine life trajectories (Busquets, Saraví, and Abrantes 2013, 78). These patterns have persisted transnationally in the United States and Oaxaca despite migration, upholding political institutions (Stephen 2007) and religious ceremonies (Gutierrez Najera 2016). CMujer, however, represents a shift away from kinship-based community toward community formation based on shared goals and solidarity. This has been thanks to new opportunities for spaces of representation (Lefebvre 1974) that have emerged from women's Borderlands identity (Anzaldúa 1987). Soja $(1996,50)$ calls this new space of representation Thirdspace, a transformational space that highlights the "constantly shifting and changing milieu of ideas, events, appearances, and meanings."

In this section, I argue that CMujer exists as a Thirdspace (Soja 1996), a unique combination of particular spaces of representation (Lefebvre 1974) created through 
Borderlands identities (Anzaldúa 1987), facilitating the construction of new types of options for community formation. Thirdspace rejects the duality of externally imposed narratives of space through spatial practices and representations of space to emphasize the transformative nature of new spaces that combine "the abstract and the concrete, the real and the imagined, the knowable and the unimaginable... [with] everyday life and unending history" (Soja 1996, 54). Women have leveraged this space of "extraordinary openness" (Soja 1996, 50) in order to enact their Borderlands consciousness. As demonstrated through Victoria's work with women in San Pablo Huixtepec described in the opening vignette of this chapter, women come together with the goal of collective empowerment via personal growth and skill development. Through their participation in CMujer, women are offering alternative models for gender identities for all women (Stephen 2005).

Theorists of social change like Greenfield (1999) and Manago (2011) argue that shifts from closed, rural, and agrarian-based communities to urban environments marked by educational opportunities and access to technology parallel shifts from a collectivist to individualist value set. Yet research in other areas of Mexico shows that organizing and educational opportunities based in community values lead to longer-term impacts on ideas about gender and women's empowerment (Eber 1999; Peterson 2014). My findings coincide with Eber (1999) and Peterson (2014). I argue that through CMujer women develop individual skills and experience personal growth that allow them to build relationships both within and outside of CMujer and the world of higher education. CMujer, like other women's organizations (Khurshid 2012; Stephen 2005, 2007), 
encourages gender equality and individual empowerment as a means of community and family empowerment. Women thus expand networks of solidarity and create "more durable changes in gender and social positions" (Peterson 2014, 150) as part of a decades-old movement in Oaxacan civil society (Avellaneda 2012). This is possible thanks to the opportunity for a Thirdspace and transformative spaces of representation that permit leadership and communication skill development and create confianza.

Lucy's success provides an outstanding example of CMujer's impact on women's skills and community goals. Revisiting Lucy's graduation speech mentioned in Chapter Two, she spoke slowly and calmly, proud of her own achievements and sincere in her gratitude and appreciation for her classmates and experiences at the UT. She highlighted CMujer as a fundamental component of her educational experience at the UT:

In 2014 I had the opportunity to form part of CMujer, and today women who were part of that cohort are graduating. It was and it is an honor to continue being a part of that project. I thank [CMujer] for teaching me that success doesn't depend on your gender but on your attitude.

Lucy was considered a leader among her peers on campus and now is the CMujer Program Coordinator, as described above. Education and participation in women's collectives and organizations have been show to develop leadership skills, including the "attitude" Lucy mentioned, that are transferrable to public contexts and roles (Espinosa Damián, Dircio Chautla, and Sánchez Néstor 2010; Stephen 1997, 2005).

In an interview with Cintia and Janeth, introduced in Chapter Three, I asked what their experiences in CMujer have been like and how it has helped them. Cintia began enthusiastically: "Centers like CMujer are awesome to give women orientation because 
in other universities the truth is not even... you're a normal girl and all that. [CMujer] changes everything." With her reference to being a "normal girl," Cintia demonstrates the hegemonic expectations for rural femininity: other universities might underestimate women's potential and contribution to the university community or privilege their role within rural spatial practices above their transformative, nepantlera role within higher education. For example, in other Mexican academic institutions, scholars have highlighted gender-based discrimination and inequality (Briseño Maas and Pérez Aguilar 2011; González Jiménez 2013; Villagómez Valdés and Sánchez González 2011). The opportunity for new spaces of representation within CMujer, a Thirdspace, "changes everything." She later cited a specific example of how the very existence of CMujer and the opportunities it presents on and off campus changed the way she thinks:

I remember when Maestra Nydia gave us a talk and the truth is she convinced us...[she] came and told us that, "You are the women that we're looking for." The truth is it was really good because I never imagined that they'd call you like that. It's for your benefit. In other universities, even though you have a good GPA, they, like, don't. They don't make you see everything that there is or what you can do. In contrast, here they do.

Cintia's reference to "everything that there is or what you can do" as a university student highlights her personal growth within the space of CMujer and new ability to see beyond previous spatial practices and representations of space. By embracing the Borderlands, Cintia is able to expand her knowledge "for [her] benefit" and ultimately for the benefit of her kinship and chosen communities.

"So what abilities are you developing?" I asked. "Leadership!" We laughed at the obvious answer. She continued: 
No but really because I like it, and my classmates, like, what I tell them they really do because I tell them, "You must do something if you want things to turn out well"... and that's what I like, like also to motivate them so they don't stay in one spot because there's a lot of conformity.

Janeth added, "The abilities that I hope to have and believe I already have are leadership, like Cintia said, communication, and teamwork." Stephen (2005) shows that women-only spaces like CMujer permit women to foster their leadership skills, like communication and teamwork, before applying them in public settings. Indeed during interviews women expressed frustration, annoyance, and tension towards male peers who questioned their leadership abilities or made rude comments during class activities. One woman even shared that she was unsure if communicating at all with men at the university would imply romantic intentions or jeopardize her reputation, as described in Chapter Three. Because students usually study in mixed-gendered contexts at the UT, stepping out of that space together provides opportunities for comparison and analysis of oppressive structures like stereotypes and role expectations (Blackwell 2006) and helps women identify, cultivate, and practice assertive communication and build self-confidence (Stephen 2005, 2007).

The CMujer team, especially Lucy and Dulce, who work with the participants often also agree that they see changes in women's self-confidence and communication skills, both in large groups and individual conversations. ${ }^{44}$ One woman, for example, described her process of improving communication as follows:

You could say like before I was a more timid person. I didn't get involved with a

\footnotetext{
${ }^{44}$ Only anecdotal evidence is available at this time, as CMujer does not yet have an evaluation plan in place.
} 
lot of people, but as a change now I lost that fear if I have a question, but before if I had a question, I just left it. I didn't trust myself. I didn't relate to others. But now well, that has changed. I feel more confianza.

As in Stephen's $(2007,256)$ research with Oaxacan women's community organizations in Woodburn, Oregon, women-only spaces "gives women the confidence to speak up" or in the student above's words, "[lose] that fear," "trust [one's] self," and "feel more confianza." La Chinita framed her feelings of confianza in terms of the ability to bond with women in similar situations and similar experiences:

I feel I have changed for the good. I establish more relationships or I communicate more with even my [female] classmates (compañeras) now...In CMujer they gave us a lot of talks about besides taking care of yourself to...not judge other women but instead to help each other out. So starting there it has given me the opportunity to not be so, well, only with my friends and that's it rather now with others (los demas). Including with other women (las demas).

Additionally she later said, "[CMujer has] taught me to not criticize my compañeras but to try to help them." As Vásquez Vásquez (2013) explains, this type of support among women is essential for full participation in community forming and belonging. She emphasizes, as does La Chinita, the importance of not "criticizing" other women but rather offering space and opportunity to speak and be heard, "to help each other out". Friendships and expanded support networks - "not...only with my friends and that's it, rather now with others" - result in a significant benefit of participation in women's groups (Stephen 2005) like CMujer. Receiving support proves essential for nepantleras who often experience conocimiento as an isolating process, becoming distressed at the separation from previous identities and facing choques in their kin communities (Rea Ángeles 2011). Finding one's nepantlera identity supported and nurtured with avenues 
for action that encourage knowledge from dual identity spheres, like the El Balero or Sembrando Oportunidades projects, helps rural women feel at home as profesionistas and members of their communities. In this Thirdspace within higher education, women change the way they view themselves (Stephen 2005) as students, leaders, future professionals, daughters, and sisters in addition to the way they view their peers and other women.

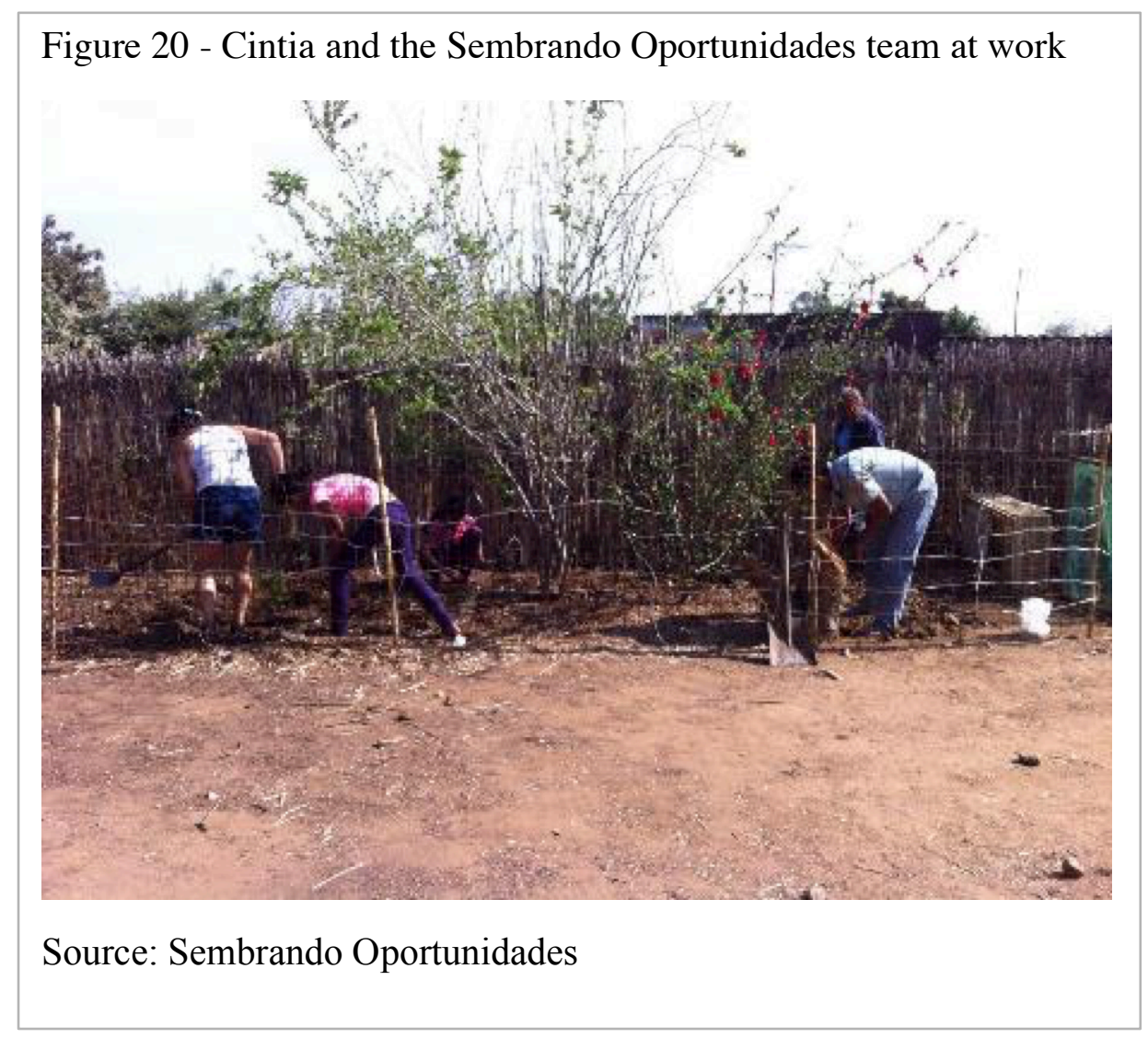

Bonds of friendship, finding commonality of experience, and appropriating a sense of ownership over the collective identity (Dalton 2010) created within CMujer are demonstrated by the way the women communicate with each other. The following 
messages ${ }^{45}$ are excerpts from a group chat celebrating the second cohort's graduation. Although I am a member of this chat group, I rarely participate and was not present for the graduation ceremony. Thus, unlike in the individual interviews quoted through this thesis, I was not the intended audience for these messages. While recognizing the possibility that my role with CMujer and positionality as a foreign researcher may alter women's portrayal of their CMujer experiences, these message excerpts demonstrate consistency with feelings expressed in individual interviews. Each woman, dedicated to her own goals in service of her community and family, views herself in relation to her peers who share common visions for gender equality and professional development.

Congratulations, CMujer, and especially much success in your projects. Everything is possible. Keep going with the same enthusiasm and bravery.

Accident, coincidence or destiny, whatever you believe in, there is one thing that is very sure: that it's a great pleasure to have met you all, that I admire you, I will miss you, and this isn't the end, but rather the beginning of many other adventures. I wish you much success in each of your projects.

I'm doing this with much love. I still have a lot to learn, but you all are one of my sources of inspiration and motivation.

We're all going to put our grain of sand in order to change what we don't like. We're going to work to build the change that our families, community, state, and the world needs. Maybe our contribution is on a small scale, but at the end of the day we will see our dreams come true.

These messages show that CMujer has created a collective identity as a strategy (Dalton 2010) for social action and change (Escobar and Alvarez 1992). Referring to everyone as "CMujer" like in the first message, "Congratulations, CMujer," indicates that women

${ }^{45}$ These messages have been edited for grammar and syntax. 
identify themselves and each other as CMujer; CMujer has become the collective identifier. Women express admiration and continuity of relationships ("this isn't the end, but rather the beginning"), underscoring their ongoing commitment to their collective project of women's empowerment and gender equality.

Escobar and Alvarez $(1992,4)$ emphasize the necessity of actions like building collective identity and relationships within the domain of "daily life" where resistance "exert[s] [its] action and influence" on hegemonic gender roles and ideas. The Thirdspace is the space of daily life where women are implementing CMujer's lessons and collective identity based in Borderlands and nepantlera identities (Anzaldúa 1987). Anzaldúa (2002, 572) likewise emphasizes that nepantla identities "advocate for mobilizing, organizing, sharing information, knowledge, insights, and resources with other groups." This is an empowering, community building experience for women (Anzaldúa 2002) as they bond over their heritage as Oaxaqueñas in particular spatial practices and representations of space, as shown in Chapter Two, and their common struggle with Borderlands and growth through conocimiento, as shown in Chapter Three. The Thirdspace as an alternative space of representation in CMujer sets the stage for individual growth and personal development with the goal of women's collective empowerment.

In the above messages, the women demonstrate their commitment to social change and collective empowerment with phrases like "build[ing] change," and contributing their "grain of sand." They also wish each other success on their respective community-based projects, both recognizing the design and implementation experience's potential for their personal and professional development and its impact on Oaxacan 
society and gender equality broadly. Through CMujer, women begin to take responsibility for creating linkages between their studies and opportunities in higher education and other women outside of the institution. Thus women have moved beyond themselves to leverage the Thirdspace (Soja 1996) into a unique space of representation available within CMujer to "desalambrar" (Hurtig, Montoya, and Frazier 2002, 2). Hurtig, Montoya, and Frazier (2002) use the term desalambrar to highlight the potential for collective action organized around gender identity to ultimately breaks through cultural and material structures of oppression in Latin America. The context of CMujer as a Thirdspace within higher education has provided an avenue to desalambrar beyond the university.

The process of desalambrar also occurs within community or family settings. For example, returning to the opening vignette of this chapter, Victoria used her major in Gastronomy and experience collaborating with CMujer as a springboard for curriculum design and collaboration with an existing women's collective in San Pablo Huixtepec. Victoria drew on collective identities as women working towards economic empowerment to create a cross-generational space that builds on traditional household reproduction patterns. Holding their meetings in each of the señora's kitchens contests traditional spatial practices of the rural kitchenspace outlined in Chapter Two. Instead of purely domestic reproduction, the group incorporates new foodmaps (Pérez 2014) baked goods and pastries - into a collective strategy for women's economic autonomy. In this way, CMujer has provided a transformational space students use as an economic,

${ }^{46}$ To undo or overrun fences 
political, and cultural tool for implementing its vision in broader Oaxacan society.

La Chinita and Lucy offer examples of how their individual development and empowerment has expanded to other generations of women and girls in their families. La Chinita has shared knowledge from CMujer with her mother and sisters. She explains:

Things that I've learned there I tell them, "Hey look this is what I know, and I am sure that things aren't done in such a way," or "Look I've see this," or "Take care of yourself once in a while, check yourself [for breast cancer]" because they also gave us classes about how to prevent diseases and all that. And also we told my mom to do it because we don't want some kind of sickness that we don't want to show up in the future, so we're in time to prevent it, to talk among us women, listen to each other, share our problems or what we're not feeling good about and improve it. So all that I practice now at home. And I feel like it's better.

By identifying knowledge and information that is relevant to her home life, La Chinita is able to leverage her Borderlands identity: she is both informed and empowered and uses her unique positionality as a nepantlera to transcend and transform spatial practices in order to connect and communicate with her mother. They can now "talk...as women, listen to each other, [and] share [their] problems." Learning to communicate about problems and emotions within CMujer as a women's space (Eber 1999) transcends to La Chinita's relationship with her mother. While La Chinita's mother may have perceived her choice to pursue higher education as motivated by individual goals, her experience supports Eber's (1999) findings that women leverage socially-embedded positionality to further movements for gender equality. La Chinita leverages her position as a daughter, Victoria draws on her emerging professional position, and Lucy models leadership as an older sister. As Anzaldúa describes in an interview, nepantleras "are the bridge" (Keating $2000,186)$ on which the movement is grounded. 
Unlike Victoria and La Chinita, who have expanded CMujer's ethos to older generations, Lucy has brought her younger sister into the Thirdspace through her project, El Balero, described earlier. In Facebook posts, pictures shared in our group chat, and in CMujer events, her five-year-old sister can often be seen beaming proudly by Lucy's side. Lucy has worked to make sure her sister feels like she is part of the El Balero team and even bought a cake to thank her for her contribution to the project and celebrate their success together. Lucy models leadership for her sister by moving in new realms of public space in leadership positions,

Figure 21 - Lucy with her mother and younger sister after presenting her final exam

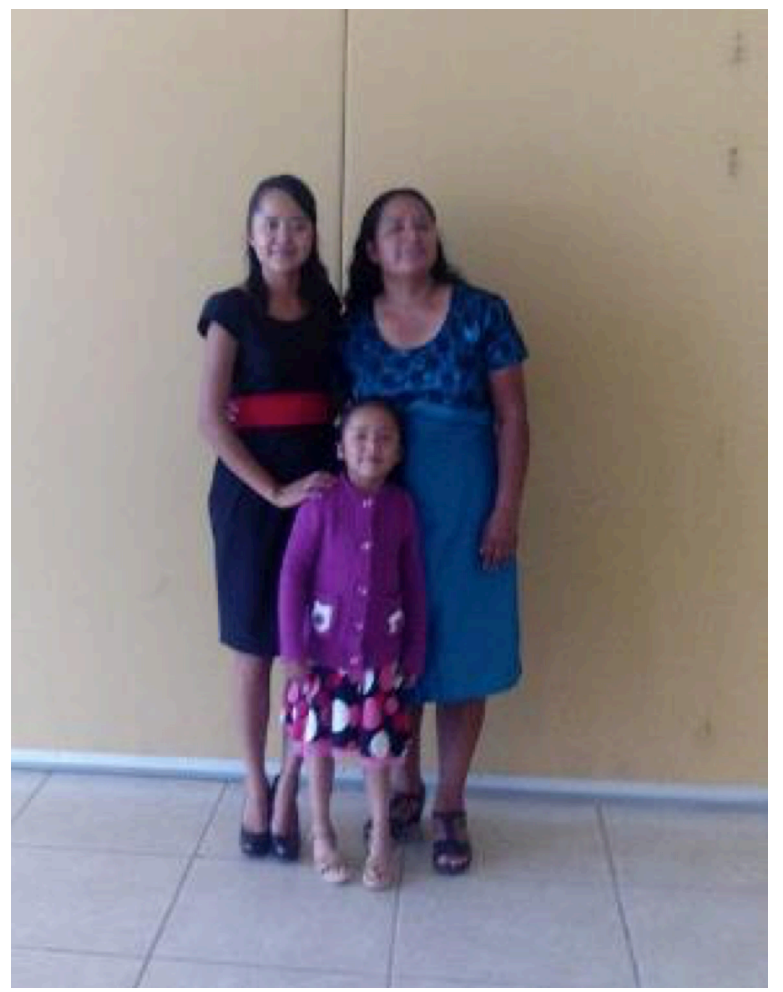

Source: Lucy automatically challenging gender inequalities (Stephen 2005) and again creating a new avenue for expanding CMujer's Thirdspace into larger contexts. Their relationship "prepare[s] the soil in which the democracy movement...take[s] root" (Eber 1999, 8). Additionally, Lucy's household and public roles have blurred (Peterson 2014), both linking to the other, much like her Borderlands identity.

In this chapter I have explored how women contest the unwanted imposition of their male peers' expectations and 
challenge gender hegemonies through leadership positions and participation in CMujer. CMujer intentionally creates alternative spaces of representation, a Thirdspace, that facilitate personal and professional development in order to promote individual and community transformation. Through CMujer, women redefine the meaning of higher education and draw on notions of individual empowerment to serve the collective good and build relationships across disciplines, generations, and geography. The Thirdspace (Soja 1996) opened by CMujer within the Borderlands (Anzaldúa 1987) of higher education redefines rural Oaxacan femininity and provides a vehicle for building regional alliances to promote gender equality and women's autonomy. 


\section{Chapter 5 - Conclusions and Recommendations: ;Pa'delante, Mujeres!}

In Chapter One I described the cultural setting and institutional context in which I conducted this research, justified my methodological approach to understanding rural women's experiences in higher education, and provided the theoretical framework I used in my analysis. I outlined the following three questions as the central focus of this thesis: (1) How is rural women's identity produced through policy, geography, and social influences? (2) In what ways do women experience change in terms of family relationships and becoming professionals? and (3) How does rural women's collective identity through professional development contribute to social movements for gender equality? In Chapter Two, I answered question one by exploring the social production of space (Lefebvre 1974) in rural Oaxacan higher education through three realms: spatial practices (physical space), representations of space (ideological space), and spaces of representation (lived space). I used contrasting kitchen spaces in rural Oaxaca and the UT as an example of differing spatial practices. Next, I analyzed university discourses, curriculum, and policies as examples of representations of space that encourage students' "transformation" while drawing on "ancestral culture." I concluded Chapter Two by unpacking the spaces of representation rural women inhabit in their daily lives as students with particular attention to urban discourses regarding gender in rural Oaxaca and rural women's bonds based in geography, values, and social class.

Chapter Three built on Chapter Two's analysis of rural women's spaces of representation by detailing the types of identity shifts and transformations students 
undergo as they progress through the university experience. I relied on Anzaldúa's (1987) Borderlands theory and concepts of nepantla and conocimiento to detail the various stages of rural women's identity development within higher education. I additionally answered question two by presenting challenges women face as a result of their perceived disconnect from rural community tradition, including social pressure related to socioeconomic mobility, family members' inexperience with education, and generational differences in understanding women's role. Chapter Three concludes with an analysis of women's embodiment of social capital and performativity as profesionistas.

In Chapter Four, I considered the University Center for Women's Leadership (CMujer) at the UT as a Thirdspace (Soja 1996) in which women create a collective identity around common goals and shared visions for gender equality. Departing from traditional community connections focused primarily on kinship networks and family ties, women converge in the space of CMujer for individual skill building and professional development. As nepantleras, rural women are able to leverage their Borderlands identities (Anzaldúa 1987) and individual empowerment within CMujer in order to affect social change at a broader level and promote the empowerment of all women in rural Oaxaca.

I conclude this thesis with a discussion of contradictions within and challenges to rural women's successful integration into an ongoing Borderlands life. Rural women's successful negotiation of these contradictions by incorporating elements of each identity - rural and profesionista - provides a bridge between the contrasting spaces of rurality and higher education (Lefebvre 1974). The extent to which Thirdspaces (Soja 1996) like 
CMujer, however, create ongoing avenues for overcoming larger socioeconomic and political forces remains to be seen. In order to continue supporting women's leadership most effectively so that nepantleras can use their skills to address their communities' challenges, I provide recommendations for CMujer that focus on improvements to and expansions of current programming. Recognizing the importance of CMujer in student retention and community building among rural women, I recommend that the UT institutionalize CMujer further, expand support of indigenous women, increase genderbased violence prevention, and retain alumnae in the CMujer community. Investing in women's leadership may ultimately prove to be a critical pathway to supporting gender equality and economic sustainability in rural Oaxaca.

\section{Contradictions and Challenges: ¿Y Ahora Qué Hacemos?}

Although nepantleras thrive in and require ambiguous and flexible identities in order to live in simultaneous words (Anzaldúa 1987), rural women must also continually negotiate contradictions as they navigate new identity expressions and leadership positions. These contradictions become especially prominent when working across spatial practices and representations of space (Lefebvre 1974). Embodying a profesionista identity, as Linda does in Chapter Three, requires conforming to hegemonic expectations of feminine professional dress (Freeman 2000). An example of women's need to balance seemingly contradictory expectations or ideas can be seen in the use of high-heeled shoes. In professional settings, women very often wear stilettos. One day while walking to the UT cafeteria with a friend and colleague, we paused to assess the rocky and uneven 
terrain leading to the building's entrance; she was unstable in her heels, and I held out my arm for her to hold onto for support.

“Amiga, why are you even wearing those things?” I asked like a typical gringa from the Pacific Northwest.

"Well, if I were taller, I wouldn't have to."

I heard this refrain time and time again as this scene played out in a variety of social situations: on sidewalks in Oaxaca City, running for cover from sudden rainstorms, during impromptu visits to agriculture fields, and the list continues. At first I am tempted to argue that if women are so inconvenienced by these shoes, they should choose more comfortable footwear that permits basic mobility through everyday circumstances. Yet, loaded with symbolism, high-heels project height and power, representing socioeconomic class through access to certain types of consumption patterns and distancing women from associations with rurality, indigeneity, or lower classes (Freeman 2000). Conforming to professional femininity's dressage (Foucault 1978), nepantleras consciously appropriate the spatial practices of the UT and professionalism. Women are able to employ stilettos as a tactic in their education and professional projects, aware of the "serious game" in which they participate while striving for class mobility (Ortner 2006).

These types of performativity (Butler 1988) conflicts underscore nepantleras' skillful ability to shift between spatial practices and representations of space (Lefebvre 1974). Indeed Anzaldúa (1990, xxvii) argues that nepantleras' "strength lies in shifting perspectives, in our capacity to shift, in our 'seeing through' the membrane of the past superimposed on the present, in our looking at our shadows and dealing with them." 
Women in CMujer recognize their "shadows" - their previous selves and associated spatial practices - and, rather than connotations associated with their shadows' darkness, draw strength from strong connections to community, family, and rural identity. Especially when dually faced with choques at home and rejection from urban peers at the UT, rural women push ahead, creating new pathways and alternative identities for all women. Temporary compromises in either identity realm ultimately remain just that: temporary. Eventually, adapting in the moment to the spatial practices of either professionalism or rurality feels natural instead of forced; rural women inhabit both at once.

Yet rural women's new identities pose additional challenges to rural communities. While investing in young women's education, parents and community elders worry about the loss of local cultural knowledge and stability of local government institutions, like usos y costumbres $^{47}$ (Aquino Zacarías 2013). Elders worry about bonds of reciprocity: will young people return to the communities that have educated them? Will they reinvest in the pueblo to ensure the next generation keeps their traditions alive? In addition to new preferences from exposure to urban and more "open" lifestyles, for rural women, a "return" to the community implies a return to the same patriarchal, oppressive structures they have worked so hard to overcome (Aquino Moreschi and Contreras Pastrana 2016). Anzaldúa (1990) argues that nepantleras must hold oppressors accountable for their actions, a difficult task in rural Oaxaca. Rural women employ the strategies and skills

47 "Tradition and custom" by which indigenous communities govern themselves. See Vásquez García (2011). 
learned in nepantla to both assuage elders' concerns and challenge hegemonic norms related to sexuality and women's leadership.

An additional challenge rural communities and women face lies in rural women's marriage and partnership prospects. What implications do nepantlera identities and adoption of multiple spatial practices hold for women's romantic relationships? While the women I interviewed all agreed they eventually want to marry, they also all agreed that they do not want to marry one of "those guys" - machistas, abusers, or cheaters. Indeed one reason some women pursue education is in order to have choice with regard to who they marry. Ana, from Chapter Three, for example, was almost forced into marriage after middle school. Esperanza, from Chapter Two, even specified in her interview that she wants to marry a guy that is at home with her, not working as a migrant in the United States. Anecdotal evidence from my own life and conversations with many women from many backgrounds suggests that education and professionalism alone do not suffice in order to avoid "those guys." This does mean, however, that women likely will look for spouses outside of the pueblo and marry someone with whom they share similar professional aspirations. Returning to reinvest in their communities becomes even more difficult, sometimes meaning that nepantleras could more easily abandon the Borderlands and live exclusively in urban, professional environments instead.

At the UT, the Thirdspace of CMujer and the Borderlands identities of rural women begin to provide pathways to facilitate women's role addressing the larger political, social, and economic forces acting on rural Oaxaca. While CMujer cannot undo the immediate impacts of migration or economic policies on rural communities, perhaps 
it can open more pathways for future generations of women and girls by support emerging women leaders. In some communities, for example, hollowed out by the effects of migration, the majority of community members actually living in the pueblo are women. Why not capitalize on these difficult circumstances to empower women and foster growth in leadership capacity? This can only happen, however, if women willingly return to their communities, where unfortunately home-based spatial practices may feel constraining and relationships with family and old friends may have fundamentally changed. Recognizing these complex challenges, in the following section, I present brief recommendations for how the UT and CMujer could continue expanding support for nepantleras. Supporting women as "bridges" between rural Oaxaca and higher education will ultimately strengthen rural communities through women's leadership.

\section{Institutionalizing and Expanding CMujer}

Because CMujer provides adaptable and culturally responsive space in which rural women shift to new types of community identity, as I show in Chapter Four, investment in its success will both increase retention of vulnerable student populations and facilitate movements for gender equality. I recommend that the UT continue its support and expansion of CMujer on campus, further institutionalizing the program as an ongoing university commitment to gender equality. Supporting women as they transition between rural Oaxaca's spatial practices and representations of space to professionalism in higher education helps ensure that conocimiento's choques do not overwhelm students. While CMujer's approach to student support should recognize and validate rural 
Oaxaca's spatial practices by incorporating traditional customs and practices into the curriculum, it also should seek to transform and build on existing structures. This would create an accessible space that affirms identity while encouraging growth. Additionally, rural women's unique position as nepantleras can strengthen university-community connections and model new examples of women's leadership in rural areas, encouraging younger girls to pursue educational opportunities. To support these objectives, CMujer should focus expansion on attention to indigenous students, gender-based violence prevention, and alumnae engagement and retention.

First, CMujer should give increased attention to indigenous women's particular positionality and experiences within CMujer. Cumes Simón (2012) highlights the need for this with her concept "patriarchal colonialism," in which indigenous women experience subjugation based on both their gender and race. Although the UT has recently begun celebrating multiculturalism and students who speak indigenous languages, CMujer has yet to explicitly prioritize indigenous women's intersectional identities within its curriculum. The Thirdspace (Soja 1996) created within CMujer holds special importance for indigenous women no longer relying solely on kinship networks for community connection and could provide a stable space for anchoring additional or new types of self-identity. Greater attention to the multiple forms of oppression indigenous women experience (Briseño Maas 2012; Cumes Simón 2014; Vásquez Vásquez 2013) in program policy and curriculum would not only increase indigenous women's success, but also facilitate broader impacts on gender equality in their distinct communities, as explored in Chapter Four. 
For example, the UT already practices the Oaxacan tradition, tequio, a type of collective work that contributes to the maintenance of the community's space, demonstrating individuals' commitment to community well-being (Martínez Luna 2010). Lebrato (2016b) outlines possible avenues for incorporating indigenous comunalidad (Martínez Luna 2010) into higher education programming, including supporting tequio. CMujer could adopt this practice within the program in order to incorporate broader Oaxacan community values and rural representations of space (Lefebvre 1974). Additionally, forming an asamblea comunitaria, a community assembly for decision making (Rendón Monzón 2003; Vásquez Vásquez 2013), within CMujer could cultivate a greater sense of collectivity, echoing rural and indigenous Oaxacan practices and encouraging women's leadership.

Next, in order to facilitate women's success in higher education, I recommend increased attention to gender-based violence education and prevention. Some initiatives on campus have already focused on this, such as implementing the United Nations Entity for Gender Equality and the Empowerment of Women's Día Naranja campaign to build awareness of gender-based violence. A recent successful Diploma Program co-sponsored through a local nonprofit, the Fondo Guadalupe Musalem, also provided a ten-week gender-based violence course. Occasional on-campus speakers address the issue broadly, and on one occasion the university radio station created a series of public service announcements detailing the common types of gender-based violence women experience. Despite increasing awareness, there is a profound lack of services on campus; the UT's psychologist is the only official resource for survivors of violence. The well-documented 
prevalence of gender-based violence in Mexico's institutions of higher education (Elder 2013; González Jiménez 2013; Tunón Pablos, Evangelista García, and Tinoco Ojanguren 2011) and anecdotal evidence from the UT underscore the importance of addressing this problem. Although my research has not specifically focused on instances of violence, during my time collaborating with the UT I have seen and heard on numerous occasions that young women, away from their parents' home for the first time, find themselves in dangerous situations. In two separate instances, indigenous women who were able to move to San Pablo under the "supervision" of their boyfriends from the pueblo ended up in violent relationships.

I recommend first that the UT allot funding for research determining the prevalence of gender-based violence on campus and then that CMujer lead initiatives to implement policies and programs in order to prevent its occurrence among the student population. For example, although the UT's Academic Guidelines detail the types of infractions that result in disciplinary action and students' rights, gender-based violence or psychological or legal support in case of its occurrence are not mentioned ("Reglamento Académico Para Los Estudiantes de La Universidad Tecnológica de Los Valles Centrales de Oaxaca" 2016). I recommend not only that the UT adopt an institutional policy guaranteeing students the right to support, but also implement programs that provide for such action. An example could include collaboration with legal advocates. In recognition of rural spatial practices and representations of space that place women in positions of vulnerability relative to their male counterparts, as is the case for the two indigenous women anecdotally mentioned above, a university-sponsored women's dormitory could 
mitigate some of the tensions around women's independence in San Pablo. These beginning efforts combined with healthy masculinities education could more broadly affect violence prevention among the UT student population.

Finally, alumnae engagement and retention within CMujer would build students' leadership capacity, expand the program's impact, and create more peer-to-peer mentoring opportunities. Currently upon completion of the CMujer program, students occasionally participate in activities, access resources through the Outreach Department, and apply for scholarships or internships. In summer 2016, a small group of alumnae met to discuss forming an alumnae committee, but without structured support and given the existing demands on students' time, the committee struggled to bring their goals to fruition. I recommend defining potential alumnae roles in order to provide women a clear pathway to engagement with CMujer upon completing the program. Examples of leadership roles could include peer outreach to recruit and encourage new participants or coordinating networking or professional development activities among alumnae. Now that two cohorts of graduates will be on campus (the majority of the first cohort has already completed their degree programs), opportunities for networking or service activities among upper and lower division students could prove beneficial for further professional development and collaboration. By positioning CMujer alumnae as peer mentors, rural women can envision their future nepantlera identities and recognize possibilities for themselves.

The UT's current administration positions CMujer favorably to meet growth and expansion expectations on campus: as of January 2017, Nydia is the new UT President. 
One challenge, however, to CMujer's longevity is personnel retention. Lucy, the Dream Team's star member, will eventually move on professionally to continue her education. Although Dulce currently does not have plans to leave the UT, other professional and personal opportunities may arise. Nydia, occupied by her duties as UT President, cannot give attention to CMujer's day-to-day operations. I myself will finish graduate school soon and continue my own professional career in Oregon. How will the Dream Team prepare others to uphold CMujer's values and implement its programs? A succession and training plan is essential, and ensuring either the UT or the sister nonprofit organizations can provide a salary for a CMujer Coordinator position will be essential moving forward.

\section{Final Reflections on Women's Leadership}

As I write this thesis in Portland, the CMujer team is hard at work in Oaxaca. I think about Lucy and Dulce working in the Outreach Department, calling out to each other from their desks to ask about a detail for a project or if they want to order lunch from the señoras making tacos outside the UT gates. When I spoke with Lucy last night, she asked about finding a replacement for her CMujer Coordinator position when she starts a graduate program in September, and Dulce and I have been sharing academic articles back and forth over Whatsapp for weeks as she writes her own thesis proposal for her graduate program. Nydia, commanding, determined, and juggling her new position's responsibilities, likely is seated in a meeting with other university administrators, all men besides her, advocating for CMujer and gender equality. I think about Lupe, whose Zapotec community in the Tlacolula Valley will host CMujer's third cohort for a service 
project consulting with women pottery makers to establish fair prices and access government grant programs. I think about Esperanza and her Gastronomy program. What new recipes has she learned? Has she prepared them for her mother, giving her a break from her usual duties cooking at home? Maybe she has introduced her community to new flavors. I think about Emma and her daughter in San Garabato, and I wonder if her family laughs about the time the gringa came to visit with Lucy and neither one of them could make tortillas. I think about Linda, whose birthday is today, and I hope her employees at her cheese selling business in the main market in Oaxaca City have bought her a cake to celebrate.

I step back from reflecting on the bonds fostered over years through this research and binational activism to contextualize the UT, CMujer, and the women introduced in this thesis. I am encouraged to know that we form part of larger global movement for gender equality. Despite recent setbacks in the United States, women and girls around the world have greater access to educational opportunities than ever before. Individual commitment to social justice and gender equality will make the difference in fostering women's leadership in the years ahead, and institutions like the UT and CMujer set an example for supporting social movements in a context of limited resources. In rural Oaxaca, nepantleras who embody multiple, complementary identities will lead the movement as bridges between two previously disparate worlds. 


\section{References}

Aguirre Sulem, Evelyn. 2013. "Transnational Migration in Mexican Indigenous Communities: An Analysis of Gender and Empowerment." University of Warwick. http://wrap.warwick.ac.uk/59470.

Anzaldúa, Gloria. 1987. Borderlands / La Frontera: The New Mestiza. 2nd ed. San Francisco: Aunt Lute Books.

. 1990. "Haciendo Caras, Una Entrada: An Introduction by Gloria Anzaldúa." In Making Face, Making Soul/Hacienda Caras: Creative and Critical Perspectives by Feminists of Color, edited by Gloria Anzaldúa, xv-xxviii. Aunt Lute Foundation Books.

—. 2002. "Now Let Us Shift...the Path of conocimiento...Inner Work, Public Acts." In This Bridge We Call Home: Radical Visions for Transformation, edited by Gloria Anzaldúa and AnaLouise Keating, 540-78. New York: Routledge.

Anzaldúa, Gloria, and Inés Hernández Ávila. 2000. "Quincentennial: From Victimhood to Active Resistance." In Gloria E. Anzaldúa: Interviews/Entrevistas, edited by AnaLouise Keating, 177-94. New York: Routledge.

Appadurai, Arjun. 1996. Modernity at Large: Cultural Dimensions of Globalization. Minneapolis, MN: University of Minnesota Press.

Aquino Moreschi, Alejandra, and Isis Contreras Pastrana. 2016. "Comunidad, Jóvenes y Generación: Disputando Subjetividades en la Sierra Norte de Oaxaca." Revista Latinoamericana de Ciencias Sociales, Niñez Y Juventud 14 (1): 463-475.

Aquino Zacarías, Plutarco. 2013. "Nuestra Comunalidad: Reflexiones Desde Yalalag." Cuadernos Del Sur 34 (1): 91-98.

Avellaneda Díaz, Ximena. 2013. El ABC de La Líder Comunitaria: Entrelazando Saberes. Oaxaca de Juárez, Oaxaca, México: Grupo de Estudios sobre la Mujer "Rosaria Castellanos", A.C.

Avellaneda, Ximena. 2012. "Políticas Públicas Para La Salud Sexual Y Reproductiva de Jóvenes Indígenas Y Quehacer de Las Organizaciones Civiles.” In Políticas Públicas, Oportunidades Y Equidad de Género, edited by Margarita Dalton and Josefina Aranda, 113-28. Oaxaca de Juárez, Oaxaca, México: Centro de Investigaciones y Estudios Superiores en Antropología Social, Unidad PacíficoSur.

Banks-Santilli, Linda. 2014. "First-Generation College Students and Their Pursuit of the 
American Dream." Journal of Case Studies in Education 5: 1.

Bartolomé, Miguel Alberto. 2014. "Las identidades imaginadas en Oaxaca: Algunos problemas del diálogo intercultural en una sociedad plural." Cuicuilco 21 (60): $83-108$.

Behar, Ruth. 1996. The Vulnerable Observer: Anthropology That Breaks Your Heart. Boston, MA: Beacon Press.

Bernard, H. Russel. 2011. Research Methods in Anthropology: Qualitative and Quantitative Approaches. 4th ed. Lanham, MD: Altamira Press.

Blackwell, Maylei. 2006. "Weaving in the Spaces: Indigenous Women's Organizing and the Politics of Scale in Mexico." In Dissident Women: Gender and Cultural Politics in Chiapas, edited by Shannon Speed, Aida Hernández Castillo, and Lynn Stephen, 115-55. Austin, TX: University of Texas Press.

Bonfil Batalla, Guillermo. 1996. México Profundo: Reclaiming a Civilization. 1st ed. Translations from Latin America Series. Austin: University of Texas Press.

Bourdieu, Pierre. 1977. Outline of a Theory of Practice. Cambridge: Cambridge University Press.

—. 1989. "Social Space and Symbolic Power." Sociological Theory 7 (1): 14.

—. 2011. "The Forms of Capital (1986)." In Cultural Theory: An Anthology, edited by Imre Szeman and Timothy Kaposy, 81-93. Malden, MA: Wiley-Blackwell.

Briseño Maas, María Leticia. 2012. “Juventudes Indígenas, Sexualidad Y Género.” In Género Y Cultura, edited by María Leticia Briseño Maas and Francisco José Ruiz Cervantes, 133-57. Oaxaca de Juárez, Oaxaca, México: Universidad Autónoma "Benito Juárez" de Oaxaca.

Briseño Maas, María Leticia, and María de Guadalupe Pérez Aguilar. 2011. "La Universidad Autónoma 'Benito Juárez' de Oaxaca Y La Reproducción de Inequidades de Género.” In Género Y Cultura Institucional, edited by Esperanza Tunón Pablos, Angélica Aremy Evangelista García, and Rolando Tinoco Ojanguren, 81-108. San Cristobal de las Casas, Chiapas, México: Colegio de la Frontera Sur.

Brubaker, Rogers, and Frederick Cooper. 2000. "Beyond 'identity." Theory and Society 29: $1-47$.

Bumpass, Larry L., Ronald R. Rindfuss, Minja Kim Choe, and Noriko O. Tsuya. 2009. "The Institutional Context of Low Fertility: The Case of Japan." Asian Population 
Studies 5 (3): 215-35.

Busquets, María Bertely, Gonzalo A. Saraví, and Pedro Abrantes. 2013. Adolescentes Indígenas En México: Derechos E Identidades Emergentes. Mexico: UNICEF \& CIESAS.

https://www.unicef.org/mexico/spanish/AdolescentesindigenasDoctecnicoOK2.pd f.

Butler, Judith. 1988. "Performative Acts and Gender Constitution: An Essay in Phenomenology and Feminist Theory." Theatre Journal 40 (4): 519.

Campbell, Joseph. 2004. The Hero with a Thousand Faces. Princeton, NJ: Princeton University Press.

Chatterjee, Partha. 1989. "Colonialism, Nationalism, and Colonialized Women: The Contest in India." American Ethnologist 16 (4): 622-33.

Christie, Maria Elisa. 2004. "Kitchenspace, Fiestas, and Cultural Reproduction in Mexican House-Lot Gardens." Geographical Review 94 (3): 368-390.

CONEVAL. 2015. "Medición de La Pobreza En México: Anexo Estadístico 2010-2014.” www.coneval.gob.mx.

Contreras Pastrana, Isis Violeta. 2014. "Colectivos Juveniles Ayuujk: Nuevas Formas de Ser Y Estar En Comunidad." Oaxaca de Juárez, Oaxaca, México: Centro de Investigación y Estudios Superiores de Antropología Social, Unidad Pacífico-Sur.

Coordinación General de Educación Media Superior y Superior, Ciencia y Tecnología. 2012. Programa de Eduacion Superior de Oaxaca 2011-2016. Oaxaca de Juárez, Oaxaca, México: Gobierno del Estado de Oaxaca.

Corbett, Jack, and Elsa Cruz Martínez. 2013. "Social Research and Reflective Practice in Binational Contexts: Learning from Cross-Cultural Collaboration." In Uncharted Terrains: New Directions in Border Research Methodology, Ethics, and Practice, edited by Anna Ochoa O'Leary, Colin M. Deeds, and Scott Whiteford, 265-74. Tucson, AZ: The University of Arizona Press.

Corbett, Jack, Nydia Mata Sánchez, and Mandy Elder. 2016. "Crossing Boundaries: Context, Culture, and Practice in Transnational Collaborations." In UniversityCommunity Partnerships, edited by B. D Wortham-Galvin, Jennifer H Allen, and Jacob Sherman, 137-48. Sheffield, UK: Greenleaf Publishing.

Cumes, Aura. 2012. "Mujeres Indígenas Patriarcado Y Colonialismo: Un Desafío a La Segregación Comprensiva de Las Formas de Dominio." In Feminismos Descoloniales: Otras Epistemologías. 
Cumes Simón, Aura Estela. 2014. "La 'India' como 'sirvienta': Servidumbre Doméstica, Colonialismo Y Patriacado En Guatemala." Mexico, D.F.: Centro de Investigación y Estudios Superiores de Antropología Social.

Curiel Covarrubias, Laura Charlynne. 2002. “De Esas Mujeres Quiere Dios': Participacion Femenina En La Reproduccion Comunitaria Y La Recreacion de La Costumbre En San Miguel Tlacotepec, Oaxaca." Masters thesis, Oaxaca de Juárez, Oaxaca, México: Centro de Investigación y Estudios Superiores de Antropología Social, Unidad Pacífico-Sur.

Dall'Alba, Gloria. 2009. "Learning Professional Ways of Being: Ambiguities of Becoming." Educational Philosophy and Theory 41 (1): 34-45.

Dalton, Margarita. 2010. Mujeres: Género e identidad en el istmo de Tehuantepec, Oaxaca. 1. ed. Publicaciones de la Casa Chata. México, D.F.: Centro de Investigaciones y Estudios Superiores en Antropología Social.

Dawkins, Richard. 1976. The Selfish Gene. Oxford University Press.

Delgado Ballesteros, Gabriela. 2012. "Género Y Educación: Políticas de Igualdad de Oportunidades." In Políticas Públicas: Oportunidades Y Equidad de Género, edited by Margarita Dalton and Josefina Aranda, 19-46. Oaxaca de Juárez, Oaxaca, México: Centro de Investigaciones y Estudios Superiores en Antropología Social, Unidad Pacífico-Sur.

Delgado Bernal, Dolores, Rebeca Burciaga, and Judith Flores Carmona. 2012. "Chicana/Latina Testimonios: Mapping the Methodological, Pedagogical, and Political." Equity \& Excellence in Education 45 (3): 363-72.

Dyrness, Andrea. 2008a. “"Confianza' Is Where I Can Be Myself': Latina Mothers' Constructions of Community in Education Reform." Ethnography and Education 2 (2): 257-271.

- 2008b. "Research for Change versus Research as Change: Lessons from a Mujerista Participatory Research Team." Anthropology \& Education Quarterly 39 (1): 23-44.

Easley Jr, Nate, Margarita Bianco, and Nancy Leech. 2012. "Ganas: A Qualitative Study Examining Mexican Heritage Students' Motivation to Succeed in Higher Education." Journal of Hispanic Higher Education 11 (2): 164-178.

Eber, Christine. 1999. "Seeking Our Own Food: Indigenous Women's Power and Autonomy in San Pedro Chenalhó, Chiapas (1980-1998)." Latin American Perspectives 26 (3): 6-36. 
Elden, Stuart. 2004. Understanding Henri Lefebvre: Theory and the Possible. Continuum Studies in Philosophy. New York, NY: Continuum.

Elder, Mandy. 2013. "La Violencia de La Marginalización.” presented at the Seminario de Género, Centro de Investigación y Estudios Superiores de Antropología Social, Oaxaca de Juárez, Oaxaca, México.

Erdreich, Lauren, and Tamar Rapoport. 2006. "Reading the Power of Spaces: Palestinian Israeli Women at the Hebrew University." City \& Society 18 (1): 116-50. doi:10.1525/city.2006.18.1.116.

Escobar, Arturo, and Sonia E. Alvarez. 1992. "Introduction: Theory and Protest in Latin America Today." In The Making of Social Movements in Latin America: Identity, Strategy, and Democracy, edited by Arturo Escobar and Sonia E. Alvarez. Series in Political Economy and Economic Development in Latin America. Boulder, CO: Westview Press.

Espinosa Damián, Gisela, Libni Iracema Dircio Chautla, and Martha Sánchez Néstor, eds. 2010. La Coordinadora Guerrerense de Mujeres Indigenas: Construyendo La Equidad Y La Ciudadanía. México, D.F.: Universidad Autónoma Metropolitana.

Flores Crespo, Pedro. 2009. "Trayectoria Del Modelo de Universidades Tecnológicas En México (1991-2009)." Cuadernos de Trabajo de La Dirección General de Evaluación Institutional 1. http://www.ses.unam.mx/curso2015/pdf/11sepFlores.pdf.

Flores-Crespo, Pedro. 2007. "Ethnicity, Identity and Educational Achievement in Mexico." International Journal of Educational Development 27 (3): 331-39. doi:10.1016/j.ijedudev.2006.10.011.

Fontana, Andrea, and James H. Frey. 2008. "The Interview: From Neutral Stance to Political Involvement." In Collecting and Interpreting Qualitative Materials, edited by Norman K. Denzin, 3rd ed., 115-60. Thousand Oaks, CA: SAGE.

Foucault, Michel. 1977. "Discipline and Punish, Trans." Alan Sheridan (New York: Vintage, 1979) 191.

- 1978. The History of Sexuality. 1st American ed. New York: Pantheon Books.

Freeman, Carla. 2000. High Tech and High Heels in the Global Economy: Women, Work, and Pink-Collar Identities in the Caribbean. Durham, NC: Duke University Press.

Fuligni, Andrew J., and Wenxin Zhang. 2004. "Attitudes toward Family Obligation among Adolescents in Contemporary Urban and Rural China." Child 
Development 75 (1): 180-92.

Gallardo Vásquez, Serafina. 2007. "El Ser Mujer Indígena Profesionista Y El Mercado de Trabajo." Aquí Estamos. Revista de Ex Becarios Del IFP 7.

Gamburd, Michele Ruth. 2000. The Kitchen Spoon's Handle: Transnationalism and Sri Lanka's Migrant Housemaids. Ithaca, NY: Cornell University Press.

"Girls' and Women's Education in Nepal." 2000. United Nations Educational, Scientific and Cultural Organization, Bangkok (Thailand). http://files.eric.ed.gov/fulltext/ED469238.pdf.

Gloria, Alberta M., Jeanett Castellanos, and Lee Jones. 2003. "Latina/o and African American Students at Predominantly White Institutions: A Psychosociocultural Perspective of Cultural Congruity, Campus Climate, and Academic Persistence." In The Majority in the Minority: Expanding the Representation of Latina/o Faculty, Administrators and Students in Higher Education, edited by Jeanett Castellanos, 71-92. Stylus Publishing, LLC.

González Cangas, Yanko. 2003. "Juventud Rural: Trayectorias Teóricas Y Dilemas Identitarios.” Nueva Antropología 19 (63): 153-75.

González Jiménez, Rosa María, ed. 2013. Violencia de Género En Instituciones de Educación Superior En México. México, D.F.: Universidad Pedagógica Nacional.

Greenfield, Patricia M. 1999. "Cultural Change and Human Development." New Directions for Child and Adolescent Development 1999 (83): 37-59.

Gutierrez Najera, Lourdes. 2016. "Zapotec Death and Mourning across Transnational Frontiers and Virtual Localities.” In Indigenous Mobilities. Minneapolis, MN.

Hale, Charles R. 2008. "Introduction." In Engaging Contradictions: Theory, Politics, and Methods of Activist Scholarship, edited by Charles R. Hale, 1-28. Berkeley, CA: University of California Press.

Hernández Aragón, Magaly. 2013. "Las Representaciones Sociales de Los Estudiantes Indígenas Sobre El Ser Universitario." In Los Estudiantes Y La Universidad: Intergración, Experiences E Identidades, edited by Carlota Guzmán Gómez, 179207. Mexico, D.F.: ANUIES.

Hill, Sarah. 2001. "The Environmental Divide: Neoliberal Incommensurability at the USMexico Border." Urban Anthropology and Studies of Cultural Systems and World Economic Development, 157-187.

Holt, Louise. 2008. "Embodied Social Capital and Geographic Perspectives: Performing 
the Habitus." Progress in Human Geography 32 (2): 227-46. doi:10.1177/0309132507087648.

Howell, Jayne. 1999. "Expanding Women's Roles in Southern Mexico: Educated, Employed Oaxaqueñas." Journal of Anthropological Research 55 (1): 99-127.

Huerta Wong, Juan Enrique, and Adriana Berumen Jurado. 2014. "El Rol de La Comunicación Familiar Y Las Redes Sociales En La Movilidad Ascendente: Historias de Vidas de Desplazamientos de Largo Tramo." Estudios Sobre Las Culturas Contemporáneas 20 (39): 69-99.

Huizar, Jose Roberto. 2015. "Outmigration and the Elderly: A Case Study of Empowerment by and for the Forgotten Generation in San Pablo Huixtepec." Masters thesis, San Diego, California: San Diego State University.

Hurtig, Janise, Rosario Montoya, and Lessie Jo Frazier. 2002. "A Desalambrar: Unfencing Gender's Place in Research on Latin America." In Gender's Place: Feminist Anthropologies of Latin America, edited by Janise Hurtig, Rosario Montoya, and Lessie Jo Frazier, 1-18. New York, NY: Palgrave Macmillan.

Instituto Nacional de Estadística y Geografía. 2014. "Perspectiva Estadística Oaxaca." México, D.F.: Instituto Nacional de Estadística y Geografía.

Instituto Nacional de Estadísticas y Geografía. 2010. "Censos de Población Y Vivienda." México, D.F.: Instituto Nacional de Estadísticas y Geografía.

Jayachandran, Seema. 2015. "The Roots of Gender Inequality in Developing Countries." Annual Review of Economics 7 (1): 63-88. doi:10.1146/annurev-economics080614-115404.

Jehangir, Rashné. 2010. "Stories as Knowledge: Bringing the Lived Experience of FirstGeneration College Students Into the Academy." Urban Education 45 (4): 53353.

Johnson, Corey W., and Diana C. Parry, eds. 2015. Fostering Social Justice through Qualitative Inquiry: A Methodological Guide. Walnut Creek, CA: Left Coast Press.

Kajanus, Anni. 2016. Chinese Student Migration, Gender and Family. New York, NY: Palgrave Macmillan.

Keating, AnaLouise. 2000. Interviews/Entrevistas: Gloria Anzaldúa. New York, NY: Routledge.

2 2006. "From Borderlands and New Mestizas to Nepantlas and Nepantleras: 
Anzaldúan Theories for Social Change.” Human Architecture 4: 5.

Khurshid, Ayesha. 2012. "A Transnational Community of Pakistani Muslim Women: Narratives of Rights, Honor, and Wisdom in a Women's Education Project: Rights, Honor, and Wisdom in a Women's Education Project." Anthropology \& Education Quarterly 43 (3): 235-52. doi:10.1111/j.1548-1492.2012.01176.x.

Koning, Anouk de. 2009. "Gender, Public Space and Social Segregation in Cairo: Of Taxi Drivers, Prostitutes and Professional Women." Antipode 41 (3): 533-556. doi:10.1111/j.1467-8330.2009.00686.x.

Lebrato, Matthew. 2016a. "Diversidad Epistemológica Y Praxis Indígena En La Educación Superior Intercultural En México: Un Caso de Estudio En El Instituto Superior Intercultural Ayuuk." Revista Mexicana de Investigación Educativa XXI (70): 785-807.

. 2016b. "Building a Framework for Indigenous/Non-Indigenous Collaborations through Comunalidad." In Indigenous and Non-Indigenous Collaborations: Exploring Notions of Evidence, Knowledge, and Discovery (Part 1). Minneapolis, $\mathrm{MN}$.

Lefebvre, Henri. 1974. The Production of Space. Translated by Donald Nicholson-Smith. Oxford, UK; Cambridge, MA: Blackwell.

Lehmann, David. 2015. "Convergencias Y Divergencias En La Educación Superior Intercultural En México." Revista Mexicana de Ciencias Políticas Y Sociales 60 (223): 133-170.

León Torres, María Soledad de. 2010. Palabra de Mujer: Familia, Género Y Narrativas En Totatiche, Jalisco. Zamora, Michoacán, México: El Colegio de Michoacán.

Levinson, Bradley AU. 2005. "Citizenship, Identity, Democracy: Engaging the Political in the Anthropology of Education." Anthropology \& Education Quarterly 36 (4): $329-340$.

Lind, David, and Elizabeth Barham. 2004. "The Social Life of the Tortilla: Food, Cultural Politics, and Contested Commodification." Agriculture and Human Values 21 (1): 47-60.

Little, Jo, and Patricia Austin. 1996. "Women and the Rural Idyll." Journal of Rural Studies 12 (2): 101-111. doi:10.1016/0743-0167(96)00004-6.

London, Howard B. 1989. "Breaking Away: A Study of First-Generation College Students and Their Families." American Journal of Education 97 (2): 144-170. doi:10.1086/443919. 
Low, Setha M. 2011. "Claiming Space for an Engaged Anthropology: Spatial Inequality and Social Exclusion." American Anthropologist 113 (3): 389-407. doi:10.1111/j.1548-1433.2011.01349.x.

Low, Setha M., and Sally Engle Merry. 2010. "Engaged Anthropology: Diversity and Dilemmas: An Introduction to Supplement 2." Current Anthropology 51 (S2): 203-26. doi:10.1086/653837.

Lucas, Kristen. 2011. "The Working Class Promise: A Communicative Account of Mobility-Based Ambivalences." Communication Monographs 78 (3): 347-69.

Lynch, Caitrin. 2007. Juki Girls, Good Girls: Gender and Cultural Politics in Sri Lanka's Global Garment Industry. Ithaca, NY: ILR Press/Cornell University Press.

Manago, Adriana M. 2011. "Shifting Meanings for Gender and the Family Among the Maya in Chiapas, Mexico." Ph.D., Los Angeles, CA: University of California, Los Angeles.

. 2012. "The New Emerging Adult in Chiapas, Mexico: Perceptions of Traditional Values and Value Change among First-Generation Maya University Students." Journal of Adolescent Research 27 (6): 663-713.

- 2014. "Connecting Societal Change to Value Differences across Generations: Adolescents, Mothers, and Grandmothers in a Maya Community in Southern Mexico.” Journal of Cross-Cultural Psychology 45 (6): 868-887.

Martínez Covarrubias, Sara G. 2006. Mujeres y universidad: vidas académicas. Colima, Michoacán: Universidad de Colima.

Martínez Luna, Jaime. 2010. Eso que llaman comunalidad. México, D.F.: Consejo Nacional para la Cultura y las Artes; Fundación Alfredo Harp Helú Oaxaca.

Mavin, Sharon, and Gina Grandy. 2016. "Women Elite Leaders Doing Respectable Business Femininity: How Privilege Is Conferred, Contested and Defended through the Body." Gender, Work \& Organization 23 (4): 379-96. doi:10.1111/gwao.12130.

Mazeran, Jacques. 2006. Las Universidades Tecnológicas Mexicanas: Un Modelo Eficaz, Una Inversión Pública Exitosa, Un Sistema a Fortalecer. Mexico, D.F.: Coordinación General de Universidades Tecnológicas.

Mendoza Gómez, Laura Thaigi. 2015. "Análisis Del Nivel de Emprendimiento En Las Mujeres Del Municipio San Vicente Lachixio, Oaxaca." Revista Observatorio de La Economía Latinoamericana, México. 
Mendoza Rojas, Javier. 2015. “Ampliación de La Oferta de Educación Superior En México Y Creación de Instituciones Públicas En El Periodo 2001-2012." Revista Iberoamericana de Educación Superior (RIES) 16 (6): 3-32.

Merrifield, Andrew. 2006. Henri Lefebvre: A Critical Introduction. New York, NY: Taylor \& Francis.

Meseguer Galván, Shantal. 2012. "Imaginarios de Futuro de La Juventud Rural: Educación Superior Intercultural En La Sierra de Zongolica, Veracruz, México." Granada, Spain: Universidad de Granada.

Miltner, Kate M. 2014. “'There's No Place for Lulz on LOLCats': The Role of Genre, Gender, and Group Identity in the Interpretation and Enjoyment of an Internet Meme." First Monday 19 (8).

Mohanty, Chandra Talpade. 2004. Feminism without Borders: Decolonizing Theory, Practicing Solidarity. Durham, NC: Duke University Press.

Momaya, Masum Khona. 2007. "The Political Is Personal, and Professional: A Cultural Analysis of Embodiment and Empowerment Narratives of Young Professional Women Working in Washington, DC.” Cambridge, MA: Harvard University.

Moreno, Rosean. 2016. "The Guilt of Success: Looking at Latino First-Generationc Ollege Students and the Guilt They Face from Leaving Their Home and Community to Pursue College." Long Beach, CA: California State University, Long Beach.

Moshi, Libia. 1998. "Foreword to Women and Education in Sub-Saharan Africa: Power, Opportunities, and Constraints." In Women and Education in Sub-Saharan Africa: Power, Opportunities, and Constraints, edited by Marianne N. Bloch, Josephine A. Beoku-Betts, and B. Robert Tabachnick. Boulder, CO: Lynne Rienner Publishers.

Muehlmann, Shaylih. 2009. "How Do Real Indians Fish? Neoliberal Multiculturalism and Contested Indigeneities in the Colorado Delta." American Anthropologist 111 (4): 468-479.

Mulvey, Laura. 1989. "Visual Pleasure and Narrative Cinema." In Visual and Other Pleasures, 14-26. London, UK: Palgrave Macmillan.

Naji, Myriem. 2012. "Learning to Weave the Threads of Honor: Understanding the Value of Female Schooling in Southern Morocco." Anthropology \& Education Quarterly 43 (4): 372-84. doi:10.1111/j.1548-1492.2012.01191.x.

Napolitano, Valentina. 2002. Migration, Mujercitas, and Medicine Men: Living in Urban 
Mexico. Berkeley, CA: University of California Press.

Nelson, Larry, Sarah Badger, and Bo Wu. 2004. "The Influence of Culture in Emerging Adulthood: Perspectives of Chinese College Students." International Journal of Behavioral Development 28 (1): 26-36. doi:10.1080/01650250344000244.

Nevarez, Carlos. 2001. "Mexican Americans and Other Latinos in Postsecondary Education: Institutional Influences." ERIC Digest.

Novo, Carmen Martínez. 2006. Who Defines Indigenous?: Identities, Development, Intellectuals, and the State in Northern Mexico. Rutgers University Press.

Ohmer, Sarah. 2010. "Gloria E. Anzaldua's Decolonizing Ritual de Conocimiento." Confluencia: Revista HIspánica de Cultura Y Literatura 26 (1): 141.

Okeke-Ihejirika, Philomina Ezeagbor. 2004. Negotiating Power and Privilege: Igbo Career Women in Contemporary Nigeria. Vol. 82. Ohio University Press.

Orbe, Mark P. 2004. "Negotiating Multiple Identities within Multiple Frames: An Analysis of First-generation College Students." Communication Education 53 (2): 131-49. doi:10.1080/03634520410001682401.

Organisation for Economic Co-operation and Development. Development Centre. 2010. Atlas of Gender and Development: How Social Norms Affect Gender Equality in Non-OECD Countries. Paris: OECD, Development Centre, OECD Publishing.

Ortner, Sherry B. 2006. Anthropology and Social Theory: Culture, Power, and the Acting Subject. Durham, NC: Duke University Press.

Pérez Aguilar, María de Guadalupe. 2012. "Estereotipos de La Mujer Mexicana Y El Sexismo En La Educación Formal.” In Género Y Cultura, edited by María Leticia Briseño Maas and Francisco José Ruiz Cervantes, 207-28. Oaxaca de Juárez, Oaxaca, México: Universidad Autónoma "Benito Juárez" de Oaxaca.

Pérez Coeto Mateos, Georgina, and Hildeliza Flores Hernández. 2007. Pautas de Crianza de Mujeres Indígenas: Proceso de Cambio Y Su Efecto En La Escolarización. Morelia, Michoacán, México: Instituto Michocano de la Mujer.

Pérez, Ramona Lee. 2014. "Las Fronteras Del Sabor: Taste as Consciousness, Kinship, and Space in the Mexico-U.S. Borderlands." The Journal of Latin American and Caribbean Anthropology 19 (2): 310-30. doi:10.1111/jlca.12094.

Peterson, Nicole D. 2014. "'We Are Daughters of the Sea': Strategies, Gender, and Empowerment in a Mexican Women's Cooperative: We Are Daughters of the Sea." The Journal of Latin American and Caribbean Anthropology 19 (1): 148- 
67. doi:10.1111/jlca.12064.

Pilcher, Jeffrey M. 2005. "Industrial Tortillas and Folkloric Pepsi: The Nutritional Consequences of Hybrid Cuisines in Mexico." In The Cultural Politics of Food and Eating: A Reader, edited by James L. Watson and Melissa L. Caldwell, 23550. Hoboken, NJ: Blackwell Publishing.

Piñón Lora, Maybel, and Cyntia Cerón Hernández. 2007. “Ámbitos Sociales de Representación Del Cuerpo Femenino: El Caso de Las Jóvenes Estudiantes Universitarias de La Ciudad de México.” Ultima Década 15 (27): 119-139.

Programa de Naciones Unidas para el Desarrollo en México. 2014. "Índice de Desarrollo Humano En México: Nueva Metodología.” México, D.F.: Programa de Naciones Unidas para el Desarrollo.

Ramírez García, Rosalba Genoveva. 2012. Cambiar, interrumpir o abandonar: la construcción de experiencias de los estudiantes en su tránsito por una institución de educación superior tecnológica. México, D.F.: ANUIES.

Raymo, James M., Hyunjoon Park, Yu Xie, and Wei-jun Jean Yeung. 2015. "Marriage and Family in East Asia: Continuity and Change." Annual Review of Sociology 41 (1): 471-92. doi:10.1146/annurev-soc-073014-112428.

Rea Ángeles, Patricia. 2011. "La Educación Superior Como Agente de Transformación de Las Identidades Genéricas Entre Los Zapotecos En La Ciudad de México.” Perfiles Educativos 33 (SPE.): 226-238.

"Reglamento Académico Para Los Estudiantes de La Universidad Tecnológica de Los Valles Centrales de Oaxaca." 2016. Gobierno del Estado de Oaxaca. http://www.utvco.edu.mx/images/Estados_finacieros/Reglamento $\% 20 \mathrm{Acad} \% \mathrm{C} 3$ $\%$ A9mico\%20para\%20los\%20Estudiantes.pdf.

Rendón Monzón, Juan José. 2003. La Comunalidad: Modo de Vida En Los Pueblos Indios. Mexico, D.F.: Consejo Nacional para la Cultura y las Artes.

Rivera, Miquel. 2010. "Latino Higher Education Students Face Grief and Loss." The Hispanic Outlook in Higher Education 21 (2): 19.

Rose, Jeff. 2016. "Ethnographic Research for Social Justice: Critical Engagement with Homelessness in a Public Park." In Fostering Social Justice through Qualitative Inquiry: A Methodological Guide, edited by Corey W. Johnson and Diana C. Parry, 129-60. Walnut Creek, CA: Left Coast Press.

Ruiz López, Arturo, and Elena Quiroz Lima. 2014. "Educación Comunitaria: Una Propuesta Alternativa Para Los Pueblos Indígenas de Oaxaca-México." Polis 
(Santiago) 13 (38): 225-241.

Rutherford, Vanessa, Paul F. Conway, and Rosaleen Murphy. 2015. "Looking like a Teacher: Fashioning an Embodied Identity through Dressage." Teaching Education 26 (3): 325-39. doi:10.1080/10476210.2014.997699.

Saldívar Hull, Sonia. 1987. "Introduction to the Second Edition." In Borderlands / La Frontera: The New Mestiza. San Francisco, CA: Aunt Lute Books.

Santiago Tlazoyaltepec. 2005. "Plan de Desarollo Integral, Sustentable Y Pluricultural." http://www.cdi.gob.mx/planes_desarrollo/oaxaca/68_santiago_tlazoyaltepec.pdf.

Saraví, Gonzalo A. 2009. Transiciones Vulnerables: Juventud, Desigualdad Y Exclusión En México. Mexico, D.F.: Centro de Investigaciones y Estudios Superiores en Antropología Social.

Schmelkes, Sylvia. 2013. "Indigenous Students as Graduates of Higher Education Institutions in Mexico." In The Education of Indigenous Citizens in Latin America, edited by Regina Cortina, 124-47. Bristol, UK: Multilingual Matters.

Secretaria de Educación Pública. 2008. "Fortalecimiento Del Subsistema de Universidades Tecnológicas: 'Su Evolución Al Nivel de Estudios 5A.'”

Silva Laya, Marisol, and Adriana Rodríguez. 2012. El Primer Año Universitario Entre Jóvenes Provenientes de Sectores de Pobreza: Un Asunto de Equidad. Districto Federal, México: ANUIES.

Soja, Edward W. 1996. Thirdspace: Expanding the Geographical Imagination. San Francisco, CA: John Wiley and Sons.

- 2009. "Thirdspace: Toward a New Consciousness of Space and Spatiality." In Communicating in the Third Space, edited by Karin Ikas and Gerhard Wagner, 49-61. New York, NY: Routledge.

Speed, Shannon. 2006. "At the Crossroads of Human Rights and Anthropology: Toward a Critically Engaged Activist Research." American Anthropologist 108 (1): 6676.

Spradley, J.P. 1980. The Ethnographic Interview. New York, NY: Holt, Rinehart, and Winston.

Stephen, Lynn. 1997. Women and Social Movements in Latin America: Power from Below. Austin, TX: University of Texas Press.

- 2005. Zapotec Women: Gender, Class, and Ethnicity in Globalized Oaxaca. 
Durham, NC: Duke University Press.

- 2007. Transborder Lives: Indigenous Oaxacans in Mexico, California, and Oregon. Durham, NC: Duke University Press.

Székely, Miguel. 2013. Educación Superior Y Desarrollo En Oaxaca. Washington D.C.: World Bank.

Taş, Emcet O., Maira Emy Reimão, and Maria Beatriz Orlando. 2014. "Gender, Ethnicity, and Cumulative Disadvantage in Education Outcomes." World Development 64: 538-53. doi:10.1016/j.worlddev.2014.06.036.

Tunóón Pablos, Esperanza, Angélica Aremy Evangelista García, and Rolando Tinoco Ojanguren, eds. 2011. Género Y Cultural Institucional. San Cristobal de las Casas, Chiapas, México: Colegio de la Frontera Sur.

Universidad Tecnológica de los Valles Centrales de Oaxaca. 2013. Modelo Educativo. http://utvco.edu.mx/index.php/institucion/modelo-educativo6.

—. 2016. "Resultados Del Censo Noviembre 2016."

Vásquez García, Verónica. 2011. Usos Y Costumbres Y Ciudadanía Femenina: Hablan Las Presidentas Municipales de Oaxaca. 1996-2010. México, D.F.: Miguel Ángel Porrúa.

Vásquez Vásquez, Juana. 2013. "La Participación de Las Mujeres En La Construcción de La Comunalidad." Cuadernos Del Sur 34 (1): 99-102.

Villagómez Valdés, Gina, and Consuelo Sánchez González. 2011. Género, Universidades Y Ciencia: Perspectiva de Género En Instituciones de Educación Superior En La Región Sur-Sureste de México. Universidad Autónoma de Campeche, Mérida, Yucatán, México: Associación Nacional de Universidades e Instituciones de Educación Superior, Red de Estudios de Género Regen, Región Sur-Sureste.

Vogt, Evon. 1969. Zinacantán: A Maya Community in the Highlands of Chiapas. Cambridge, MA: Belknap Press of Harvard University Press.

Weiss, Brad. 2011. "Making Pigs Local: Discerning the Sensory Character of Place." Cultural Anthropology 26 (3): 438-61. doi:10.1111/j.1548-1360.2011.01106.x.

Zaytoun, Kelli. 2006. "Theorizing at the Borders: Considering Social Location in Rethinking Self and Psychological Development." NWSA Journal 18 (2): 52-72. 


\section{Appendices}

\section{Appendix A: Tables and Figures (Chapter 1)}

Figure 22 - Percent of municipalities in each Mexican state according to huamn development index ranking

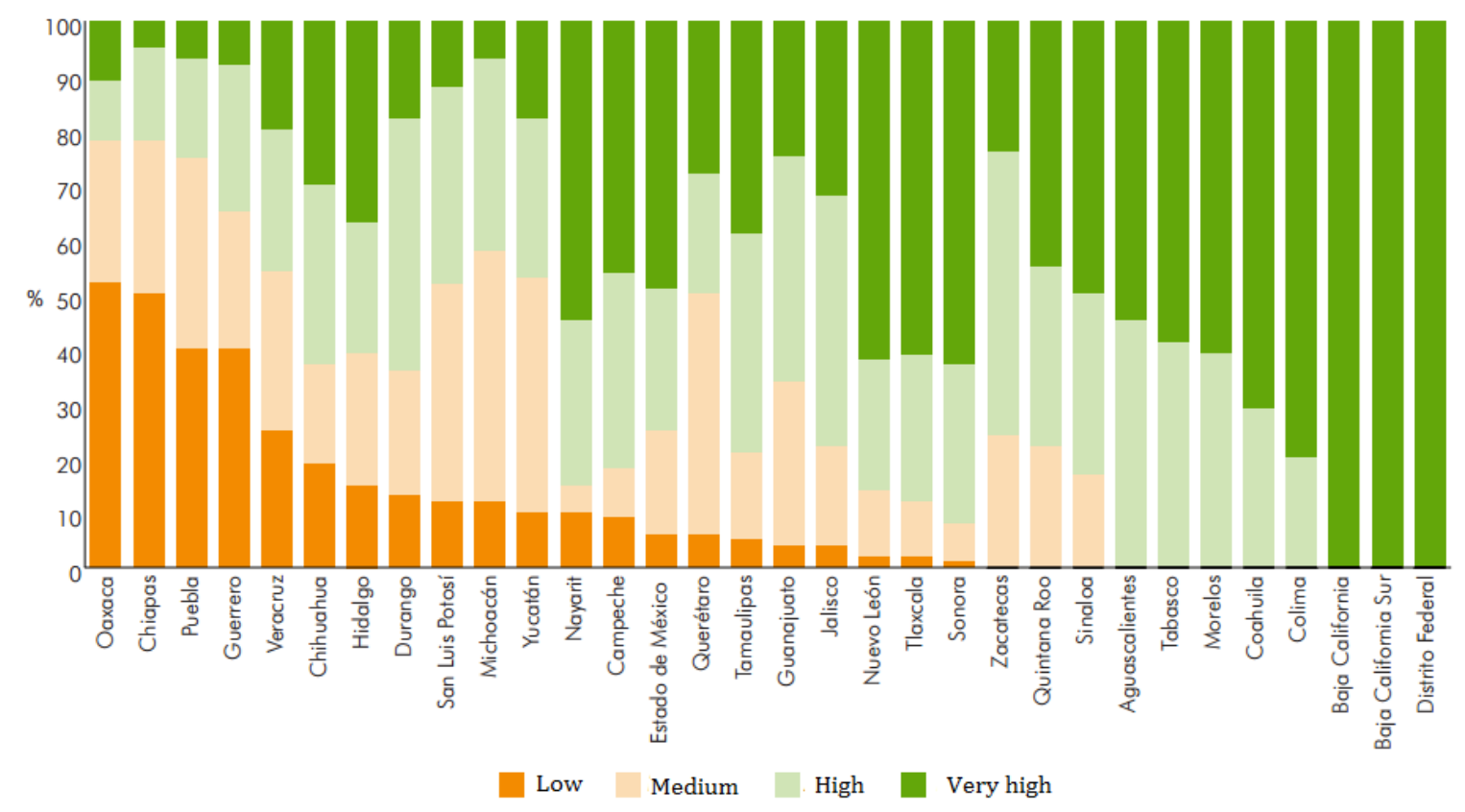

Source: Programa de Naciones Unidas para el Desarrollo en México (2014)

Figure 23 - Percentage of population in poverty nationwide

\begin{tabular}{|l|c|c|c|}
\hline & $\mathbf{2 0 1 0}$ & $\mathbf{2 0 1 2}$ & $\mathbf{2 0 1 4}$ \\
\hline Urban & & & \\
\hline Moderate poverty & 33.7 & 34.3 & 35.4 \\
\hline Extreme poverty & 6.7 & 6.3 & 6.2 \\
\hline Rural & & & \\
\hline Moderate poverty & 38.5 & 40.1 & 40.5 \\
\hline Extreme poverty & 26.5 & 21.5 & 20.6 \\
\hline
\end{tabular}

Source: CONEVAL 2015 
Figure 24 - Number of students self-identified according to language group at the Universidad Tecnológica de los Valles Centrales de Oaxaca as of December 2016

\begin{tabular}{|l|c|}
\hline Indigenous language & Number of students \\
\hline Chatino & 3 \\
\hline Chinanteco & 7 \\
\hline Chontal & 2 \\
\hline Cuicateco & 3 \\
\hline Mazateco & 1 \\
\hline Mixe & 10 \\
\hline Mixteco & 12 \\
\hline Triqui & 2 \\
\hline Zapoteco & 120 \\
\hline
\end{tabular}

Source: Universidad Tecnológica de los Valles Centrales de Oaxaca 2016 
Figure 25 - Number of students by major at the Universidad Tecnológica de los Valles Centrales de Oaxaca as of December 2016

\begin{tabular}{|c|c|c|c|c|c|}
\hline \multirow[b]{2}{*}{ Major } & \multicolumn{2}{|c|}{ Men } & \multicolumn{2}{|c|}{ Women } & \multirow[b]{2}{*}{$\begin{array}{l}\text { Total students } \\
\text { in program }\end{array}$} \\
\hline & $\begin{array}{c}\text { Number } \\
\text { of } \\
\text { students }\end{array}$ & $\begin{array}{l}\text { Percent of } \\
\text { program }\end{array}$ & $\begin{array}{c}\text { Number } \\
\text { of } \\
\text { students }\end{array}$ & $\begin{array}{l}\text { Percent of } \\
\text { program }\end{array}$ & \\
\hline \multicolumn{5}{|c|}{ Four-Year Programs } & 346 \\
\hline $\begin{array}{l}\text { Renewable } \\
\text { Energies }\end{array}$ & 41 & 69 & 18 & 31 & 59 \\
\hline $\begin{array}{l}\text { Business } \\
\text { Development } \\
\text { and Innovation }\end{array}$ & 35 & 41 & 51 & 59 & 86 \\
\hline Mechatronics & 8 & 100 & 0 & 0 & 8 \\
\hline $\begin{array}{l}\text { Food } \\
\text { Biotechnologies }\end{array}$ & 1 & 8 & 11 & 92 & 12 \\
\hline $\begin{array}{l}\text { Information } \\
\text { Technologies }\end{array}$ & 23 & 70 & 10 & 30 & 33 \\
\hline Gastronomy & 66 & 45 & 82 & 55 & 148 \\
\hline \multicolumn{5}{|c|}{ Two-year programs } & 737 \\
\hline $\begin{array}{l}\text { Business } \\
\text { Development }\end{array}$ & 67 & 30 & 158 & 70 & 225 \\
\hline $\begin{array}{l}\text { Renewable } \\
\text { Energies }\end{array}$ & 62 & 70 & 27 & 30 & 89 \\
\hline Gastronomy & 133 & 49 & 138 & 51 & 271 \\
\hline Mechatronics & 21 & 81 & 5 & 19 & 26 \\
\hline $\begin{array}{l}\text { Information and } \\
\text { Communication } \\
\text { Technologies }\end{array}$ & 97 & 77 & 29 & 23 & 126 \\
\hline
\end{tabular}

Source: Universidad Tecnológica de los Valles Centrales de Oaxaca 2016

\section{Appendix B: Methodological Tools}

Original Spanish vignette presented to participants:

Lupita es la hermana mayor en una familia de tres hijos. El papá de Lupita es albañil y su mamá es ama de casa quien a veces vende en el mercado. Cuando Lupita se graduó del bachillerato enfrentó una larga serie de desafíos para poder continuar sus 
estudios. Con el apoyo de sus papás, ella logró ingresar a la UTVCO y ahora es la primera en su familia que estudia la universidad. Sus papás están muy orgullosos y siempre le apoyan en lo que pueden.

Cuando empezó a estudiar en la UTVCO, Lupita rentaba en San Pablo pero iba seguido a su casa para estar con su familia y ayudar con los labores que le correspondían. A veces se le juntaron los trabajos de la escuela y ya no le daba mucho tiempo para terminar todo, pero estar otra vez en el abrazo familiar de su mamá le ayudaba a no sentirse tan solita durante la semana.

Ahora que va en el quinto cuatrimestre, regresa a casa cada 15 o 20 días. Ya no se siente tan sola en San Pablo y hasta le gusta ir con sus compañeros a pasear en los fines. Entre los viajes de práctica y trabajos en equipo, Lupita se da cuenta de que hay mucho por aprender en la UT y se invierte más en su carrera y vida personal que se va desarrollando en San Pablo. Por lo mismo de que Lupita se encuentra en un ambiente nuevo por primera vez, su forma de ser ha empezado a cambiar en ciertos aspectos. A veces sus papás le hacen comentarios cuando no regresa a la comunidad y no falta una que otra tía que le hace feo de vez en cuando por no involucrarse tanto como antes en los labores de la casa y en la vida comunitaria.

\section{English translation of vignette:}

Lupita is the oldest daughter in a family of three children. Lupita's father is a construction worker and her mother is a homemaker who sometimes sells at the market. When Lupita graduated from high school, she encountered a long series of challenges to 
be able to continue her studies. With her parents' support, she was able to register at the UT, and she is now the first in her family to study at a university. Her parents are very proud, and they always support her with whatever they can.

When she started studying at the UT, Lupita rented in San Pablo, but she went home often to be with her family and help with the housework she was responsible for. Sometimes work piled up at school, and it didn't give her a lot of time to finish everything, but being at home in her mother's arms helped her to not feel so lonely during the week.

Now that she's in her fifth quarter, she returns home every two or three weeks. She doesn't feel so lonely in San Pablo, and she even likes going out with her friends on the weekend. Between field trips and group work, Lupita realizes that there is a lot to learn at the UT, and she invests herself more in her studies and personal life she is developing in San Pablo. Because Lupita is a new environment for the first time, her way of being has started to change in some ways. Sometimes her parents remark when she doesn't go home to her community, and there's always an aunt or someone that is rude once in a while because she isn't as involved in household chores and community life as much anymore. 
Figure 26 - Renewable Energies meme

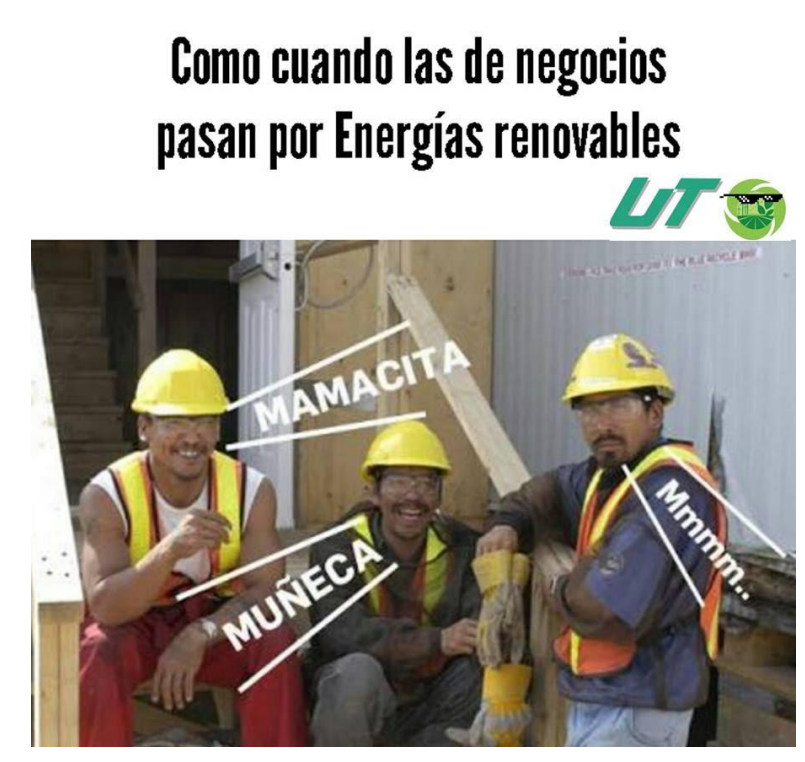

"Like when women from Business Development pass by Renewable Energies." "Mamacita! Doll! Mmmm..."
Figure 27 - Gastronomy meme

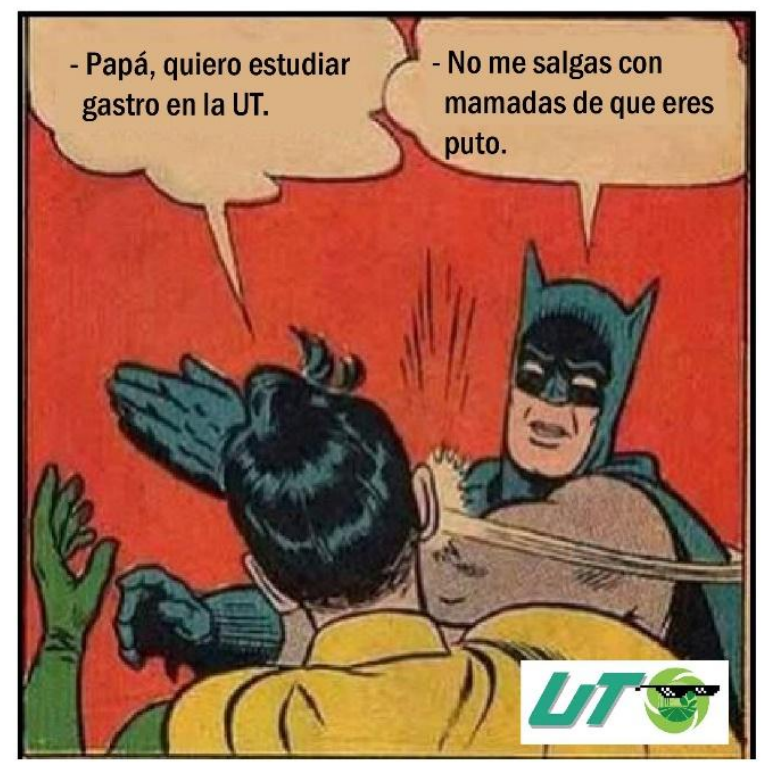

"Dad, I want to study Gastronomy at the UT." "Don't give me that bullshit that you're gay." 